UNIVERSIDADE DE SÃO PAULO

PROGRAMA DE PÓS-GRADUAÇÃO EM ENGENHARIA ELÉTRICA

Ricardo de Souza Jacomini

\title{
INFERÊNCIA DE REDES GÊNICAS POR AGRUPAMENTO, BUSCA EXAUSTIVA E ANÁLISE DE PREDIÇÃO INTRINSECAMENTE MULTIVARIADA
}


Ricardo de Souza Jacomini

\section{INFERÊNCIA DE REDES GÊNICAS POR AGRUPAMENTO, BUSCA EXAUSTIVA E ANÁLISE DE PREDIÇÃO INTRINSECAMENTE MULTIVARIADA}

Tese apresentada à Escola Politécnica da Universidade de São Paulo como requisito para obtenção do Título de Doutor em Ciências. 
Ricardo de Souza Jacomini

\section{INFERÊNCIA DE REDES GÊNICAS POR AGRUPAMENTO, BUSCA EXAUSTIVA E ANÁLISE DE PREDIÇÃO INTRINSECAMENTE MULTIVARIADA}

Tese apresentada à Escola Politécnica da Universidade de São Paulo como requisito para obtenção do Título de Doutor em Ciências.

Àrea de Concentração:

Engenharia de Computação

Orientador:

Prof. Dr. David Corrêa Martins Junior 
Este exemplar foi revisado e alterado em relação à versão original, sob responsabilidade única do autor e com a anuência de seu orientador.

São Paulo, 20 de agosto de 2017.

Assinatura do autor:

Assinatura do orientador:

Catalogação-na-publicação

Jacomini, Ricardo de Souza

Inferência de redes gênicas por agrupamento, busca exaustiva e análise de predição intrinsecamente multivariada/ R. S. Jacomini. - versão corr. - São Paulo, 2017.

$80 \mathrm{p}$.

Tese (Doutorado) - Escola Politécnica da Universidade de São Paulo. Departamento de Engenharia de Computação e Sistemas Digitais (PCS).

1. Redes de Regulação Gênica 2. Redes Gênicas Probabilísticas 3. Agrupamento I. Universidade de São Paulo. Escola Politécnica. Departamento de Engenharia de Computação e Sistemas Digitais (PCS). II. t. 


\section{Epígrafe}

Não é sobre chegar no topo do mundo

E saber que venceu

É sobre escalar e sentir

Que o caminho te fortaleceu.

Ana Vilela 


\section{Dedicatória}

Primeiramente à Deus.

Aos meus orientadores Anna Helena Reali Costa e David Corrêa Martins Junior professores e amigos, prontamente dispostos a ensinarem, foram fontes de energias positivas. Sem eles este trabalho não teria êxito, suas contribuições na minha formação como pesquisador foram imensuráveis.

À meu pai e amigo Aile Jacomini, pela simplicidade em que leva a vida, sempre me ensinando. À minha mãe Maria Ferreira de Souza (Loló) e minha avó Luíza Ferreira Luz, por me mostrarem que nunca é tarde para estudar, são minhas fontes de luz. Aos meus irmãos e ao Admir Aparecido Rodrigues, sempre me incentivando a prosseguir nos estudos, principalmente na área acadêmica.

Ao meu filho Gabriel de Moura Jacomini, que esse trabalho seja mais uma vez fonte de inspiração, mostrando que há sempre mais para aprender.

Aos pais e irmãos da minha esposa, considero-os meus pais e irmãos.

À minha esposa Tais Nunes Alexandre, o amor da minha vida, uma pessoa especial que Deus colocou no meu caminho. Companheira, amiga e cúmplice, sempre me apoiando durante esses anos de estudos. 


\section{Agradecimentos}

Agradeço primeiramente à Deus pela Graça, saúde, luz e força para realizar este trabalho.

Ao meu orientador e amigo professor doutor Marcelo Zanchetta do Nascimento, agradeço pela sabedoria transmitida durante o mestrado, que foi o início deste caminho.

À minha orientadora professora doutora Anna Helena Reali Costa, pelas suas orientações precisas e pontuais, exemplo de postura ética e profissional. Por ter me aceitado como aluno de doutorado, e por ter participado ativamente na minha formação.

Ao meu orientador e amigo professor doutor David Corrêa Martins Junior, que teve muito trabalho para me orientar, sempre disposto a sanar as dúvidas. Embora sem caráter oficial no início, nunca poupou esforços para ajudar mesmo durante as madrugadas. Gostaria de registrar aqui a sua dedicação excepcional à pesquisa e ensino, sem o David esse trabalho não seria concluído.

Aos amigos internacionais da Colômbia: Juan Carlos Perafan Villota (exemplo de resiliência) e Walter Mauricio Mayor Toro; da Alemanha: Ruben Glatt e Davoud Taghawi-Nejad; e de Cuba: Javier Martinez Silva, pela experiência e oportunidade de conviver com culturas distintas.

Aos amigos Leandro Luque e Vladmir Emiliano Moreira Rocha, pela troca de experiência e conhecimento. Aos amigos nordestinos que de alguma forma sempre trouxeram alegria ao LTI, tornando a convivência agradável em um ambiente sério: Heider Berlink de Souza, Allan Diego Silva e Gustavo Augusto Lima de Campos.

Aos colegas do programa de pós-graduação, do Laboratório de Técnicas Inteligen- 
tes (LTI), e alunos orientandos do professor David da Universidade Federal do ABC (UFABC), não esquecendo dos professores do LTI, Jaime Simão Sichman e Anarosa Alves Franco Brandão, que de alguma forma, contribuíram para a minha pesquisa.

À professora doutora Liria Matsumoto Sato e seu orientando de doutorado e amigo Cleber Silva Ferreira da Luz, por terem emprestado recursos computacionais fundamentais para conclusão dos resultados apresentados neste trabalho.

Aos técnicos em informática e a todos das secretarias, tanto do programa, como da Engenharia Elétrica, que estavam sempre nos apoiando.

Ao Alexandre Locci Martins do Instituto de Matemática e Estatística (IME) pelos momentos que passamos juntos estudando e aprendendo como agrupar dados de DNA complementar, apresentado na disciplina de Introdução à Biologia de Sistemas.

Ao Danilo Carastan dos Santos, de forma prestativa ao final de uma palestra que ministrava na Universidade Federal do ABC (UFABC) sobre esta pesquisa, compartilhou um software iniciado por ele e seus orientadores. Com esta iniciativa esse software evoluiu para o arcabouço apresentado nesta tese.

Ao aluno doutorando Thales Kronenberge do departamento de Parasitologia do Instituto de Ciências Biomédicas (USP), pelas contribuições fundamentais sobre análises biológicas, que nos auxiliaram e que servirão como ponto de partida para trabalhos futuros.

Em especial ao amigo Felipe Leno da Silva, pela simplicidade e dedicação que conduz seus trabalhos, pela forma que compartilha seus conhecimentos e pela oportunidade de sermos coautores em alguns trabalhos.

À Escola de Politécnica da Universidade de São Paulo e a Engenharia de Computação e Sistemas Digitais (PCS), mais especificamente ao Programa de Engenharia de Computação por colocar sua estrutura à minha disposição. E à professora Maria Cristina Vidal Borba pelo curso de redação acadêmica em inglês.

À Comissão de Aperfeiçoamento de Pessoal do Nível Superior (CAPES) pelo apoio financeiro por 24 meses que tornaram possível o desenvolvimento deste trabalho após a qualificação.

E novamente, ao amigo e companheiro Farello pelas inúmeras vezes em que me alertou que era importante fazer pausas, e juntos ao Sol, repor as energias e renovar as forças para continuar este trabalho. 


\section{Resumo}

A inferência de redes gênicas (GN) a partir de dados de expressão gênica temporal é um problema crucial e desafiador em Biologia Sistêmica. Os conjuntos de dados de expressão geralmente consistem em dezenas de amostras temporais e as redes consistem em milhares de genes, tornando inúmeros métodos de inferência inviáveis na prática. Para melhorar a escalabilidade dos métodos de inferência de GNs, esta tese propõe um arcabouço chamado GeNICE, baseado no modelo de redes gênicas probabilísticas. A principal novidade é a introdução de um procedimento de agrupamento de genes, com perfis de expressão relacionados, para fornecer uma solução aproximada com complexidade computacional reduzida. Os agrupamentos definidos são usados para reduzir a dimensionalidade permitindo uma busca exaustiva mais eficiente pelos melhores subconjuntos de genes preditores para cada gene alvo de acordo com funções critério multivariadas. GeNICE reduz consideravelmente o espaço de busca porque os candidatos a preditores ficam restritos a um gene representante por agrupamento. No final, uma análise multivariada é realizada para cada subconjunto preditor definido, visando recuperar subconjuntos mínimos para simplificar a rede gênica inferida. Em experimentos com conjuntos de dados sintéticos, GeNICE obteve uma redução substancial de tempo quando comparado a uma solução anterior sem a etapa de agrupamento, preservando a precisão da predição de expressão gênica mesmo quando o número de agrupamentos é pequeno (cerca de cinquenta) e o número de genes é grande (ordem de milhares). Para um conjunto de dados reais de microarrays de Plasmodium falciparum, a precisão da predição alcançada pelo GeNICE foi de aproximadamente $97 \%$ em média. As redes inferidas para os genes alvos da glicólise e do apicoplasto refletem propriedades topológicas de redes complexas do tipo "mundo pequeno" e "livre de escala", para os quais grande parte das conexões são estabelecidas entre os genes de um mesmo módulo e algumas poucas conexões fazem o papel de estabelecer uma ponte entre os módulos (redes mundo pequeno), e o grau de distribuição das conexões entre os genes segue uma lei de potência, na qual a maioria dos genes têm poucas conexões e poucos genes (hubs) apresentam um elevado número de conexões (redes livres de escala), como esperado.

Palavras chave: Redes de Regulação Gênica, Redes Gênicas Probabilísticas, Redes Complexas, Agrupamento, Seleção de Características, Busca Exaustiva, Predição Intrinsecamente Multivariada 


\section{Abstract}

Gene network (GN) inference from temporal gene expression data is a crucial and challenging problem in Systems Biology. Expression datasets usually consist of dozens of temporal samples, while networks consist of thousands of genes, thus rendering many inference methods unfeasible in practice. To improve the scalability of GN inference methods, this work proposes a framework called GeNICE, based on Probabilistic Gene Networks; the main novelty is the introduction of a clustering procedure to group genes with related expression profiles, to provide an approximate solution with reduced computational complexity. The defined clusters were used to perform an exhaustive search to retrieve the best predictor gene subsets for each target gene, according to multivariate criterion functions. GeNICE greatly reduces the search space because predictor candidates are restricted to one representative gene per cluster. Finally, a multivariate analysis is performed for each defined predictor subset to retrieve minimal subsets and to simplify the network. In experiments with in silico generated datasets, GeNICE achieved substantial computational time reduction when compared to an existing solution without the clustering step, while preserving the gene expression prediction accuracy even when the number of clusters is small (about fifty) relative to the number of genes (order of thousands). For a Plasmodium falciparum microarray dataset, the prediction accuracy achieved by GeNICE was roughly $97 \%$ on average. The inferred networks for the apicoplast and glycolytic target genes reflects the topological properties of "small-world"and "scale-free"complex network models in which a large part of the connections is established between genes of the same functional module (smallworld networks) and the degree distribution of the connections between genes tends to form a power law, in which most genes present few connections and few genes (hubs) present a large number of connections (scale-free networks), as expected.

Keywords: Gene Regulatory Networks Inference, Probabilistic Gene Networks, Complex Networks, Clustering, Feature Selection, Exhaustive Search, Intrinsically Multivariate Prediction 


\section{Sumário}

Lista de Ilustrações I

Lista de Tabelas $\quad$ V

$\begin{array}{ll}\text { Lista de Abreviaturas e Siglas } & \text { VI }\end{array}$

Lista de Símbolos

1 Introdução 1

1.1 Contexto e justificativa . . . . . . . . . . . . . 1

1.2 Objetivos e contribuições . . . . . . . . . . . . 3

1.3 Organização do texto ................... 5

2 Fundamentação teórica 6

2.1 Fundamentos de Sistemas Complexos . . . . . . . . . . . 6

2.2 Breve histórico sobre Teoria dos Grafos e Redes Complexas . . . . . 7

2.2.1 Fundamentos de Redes Complexas .......... . . 9

2.2.2 Redes Aleatórias de Erdös-Rényi . . . . . . . . . . 10

2.2.3 Redes Mundo Pequeno . . . . . . . . . . . . . . . . . . . 11

2.2.4 Redes Livres de Escala . . . . . . . . . . . . . . . . . . . 12

2.3 Fundamentos Biológicos . . . . . . . . . . . . . . . . 14

2.3.1 Ácidos Nucleicos e Nucleotídeos . . . . . . . . . . . 14

2.3.2 Ácido Desoxirribonucleico - DNA . . . . . . . . . . . . 14

2.3.3 Ácido Ribonucleico - RNA . . . . . . . . . . . . . . . 16 
2.3.4 Transferência de Informação Genética . . . . . . . . . . . . . 16

2.3.5 Dados de Expressão Gênica . . . . . . . . . . . . . . 19

2.4 Redes de Regulação Gênica . . . . . . . . . . . . . . . . . . . 21

2.4.1 Considerações preliminares sobre modelagem e inferência . . 21

2.4 .2 Redes Booleanas . . . . . . . . . . . . . . . 24

2.4.3 Redes Booleanas Probabilísticas . . . . . . . . . . 25

2.4.4 Redes Gênicas Probabilísticas . . . . . . . . . . . . 27

2.4.5 Inferência de Redes Gênicas Probabilísticas . . . . . . . . . 27

2.5 Seleção de Características . . . . . . . . . . . . . . . . . . . . 31

2.6 Agrupamento ......................... 37

3 Abordagem proposta para inferência de redes gênicas probabilísticas 41

3.1 Dados de Expressão Gênica . . . . . . . . . . . . . . . . . . . . 41

3.2 Normalização . . . . . . . . . . . . . . . . . . . . . . . . 42

3.3 Quantização . . . . . . . . . . . . . . . . 42

3.4 Agrupamento ......................... 43

3.5 Seleção de Caraterísticas . . . . . . . . . . . . . . . . . . 44

3.6 Análise Multivariada . . . . . . . . . . . . . . . . . . . 45

3.7 Construção da PGN . . . . . . . . . . . . . . . . . 4 46

3.8 Análise de Complexidade Computacional . . . . . . . . . . . . . 48

3.9 Software Implementado . . . . . . . . . . . . . . . . . . . . . . . 48

4 Configuração experimental $\mathbf{5 0}$

4.1 Dados Simulados . . . . . . . . . . . . . . . 50

4.1 .1 Parametrização . . . . . . . . . . . . . 50

4.1 .2 Forma de avaliação . . . . . . . . . . . . . . . 51

4.2 Microarrays de Plasmodium falciparum . . . . . . . . . . . . . 52

4.3 Hardware e software envolvidos nos experimentos . . . . . . . . . 54

5 Resultados experimentais e discussão

5.1 Dados de expressão simulados . . . . . . . . . . . . . . . 55

5.1.1 Comparação entre o GeNICE e Busca Exaustiva Pura . . . . . 55

5.1.2 Avaliação da precisão dos perfis de expressão dos genes . . . 57 
5.2 Microarrays de Plasmodium falciparum . . . . . . . . . . . 58

5.2.1 Avaliação da precisão de predição dos perfis de expressão dos genes .......................... 58

5.2.2 Avaliação topológica envolvendo dados reais . . . . . . . . . 59

$\begin{array}{llr}6 & \text { Conclusão } & 67\end{array}$

6.1 Trabalhos futuros . . . . . . . . . . . . . . . . 69

$\begin{array}{ll}\text { REFERENNCIAS } & 71\end{array}$ 


\section{Lista de Ilustrações}

1 À esquerda: a Ponte Königsberg antes de 1875 com a ilha Kneiphof (A) e a faixa de terra (D) entre duas vertentes do rio Pregel (C e B). À direita: sua representação em forma de grafo. Fonte: (BARABÁSI, 2014a, p. 10) adaptado. . . . . . . . . . . . . . . .

2 A forma exata da distribuição de graus de uma rede aleatória é a distribuição de Poisson. A linha vertical cinza mostra o grau médio $<k>=$ 5,61. Fonte: (BARABÁSI, 2014b) - adaptado. . . . . . . . . . .

3 Exemplo de uma rede livre de escala. (a) rede real de interação de proteínas de levedura; (b) Distribuição de graus dessa rede; (c) um gráfico $\log -\log$, no qual é plotado o $\log p_{k}$ em função de $\ln k$, onde $k$ é o grau. Fonte: (BARABÁSI, 2014b) - adaptado. . . . . . . . . . . .

4 À direita: o modelo de dupla hélice, os degraus horizontais representam o pares de bases do DNA, mostrando os pares de base AT e GC. À esquerda: a estrutura do RNA, sendo que a timina é substituída pela uracila. Fonte: (THOMPSON; THOMPSON, 1993) - adaptado. . . .

5 O fluxo de informações genéticas de acordo com o dogma central da biologia molecular. Replicação, transcrição e tradução ocorrem em todos os organismos; a transcrição reversa ocorre em células infectadas por determinados vírus de RNA. A transferência de informações de RNA para RNA durante a replicação dos vírus de RNA não é mostrada. Fonte: (SNUSTAD; SIMMONS, 2017) - adaptado. . . . . . . . . . .

6 A expressão gênica ocorre em duas etapas: transcrição e tradução, tanto em procariotos (a) quanto em eucariotos (b). Em eucariotos, muitas vezes os transcritos primários ou pré-mRNA têm de ser processados por excisão de íntrons e acréscimo de caps 5' de 7-metilguanosina e de cauda poli(A) 3' $\left[(A)_{n}\right]$. Além disso, os mRNA eucarióticos têm de ser transportados do núcleo para o citoplasma, onde são traduzidos. Fonte: (SNUSTAD; SIMMONS, 2017) - adaptado. . . . . . . . . . . 
7 Exemplos de matrizes de DNA Microarrays discretizadas $(N \times M)$ : (a) a linha representa os dados (ou perfil) de expressão do gene 5 em todos os experimentos (ou instantes de tempo); e a coluna em destaque na cor azul, a expressão no tempo $(t+2)$ de todos os genes; (b) Dados discretizados (quantizados) . . . . . . . . . . . . .

8 Visão esquemática de uma rede gênica simples. O gene A regula a sua própria expressão e a expressão do gene B. Deste modo, o gene pode exercer a sua influência reguladora direta (se ele codifica um FT) ou indiretamente (se ele controla a atividade de um outro FT, possivelmente através de uma cascata de sinalização). Ao reconstruir a GRN, muitas vezes tem-se como objetivo inferir um modelo de rede. Fonte: (HECKER et al., 2009) - adaptado. . . . . . . . . . . . . . . . . . . . .

9 Processo de análise de redes de regulação gênica. Os retângulos representam procedimentos que realizam um certo processamento, os triângulos representam fontes de informação e as setas indicam o fluxo da informação. Fonte: (DE-JONG, 2002) - adaptado. . . . . . . . . .

10 (a) Uma rede de três elementos binários (dígrafo); (b) Tabela de transição de estados possíveis da rede de 3 elementos do lado esquerdo, da matriz de $8 \times 3$ e abaixo do instante $(t)$; O estado subsequente no momento $(t+1)$, está à direita da tabela; (c) Um grafo mostrando a sequência de transições de estado que levam a um estado de comprimento 3. Fonte: (KAUFFMAN, 1969) - adaptado. . . . . . . . . . .

11 As principais etapas tipicamente executadas para inferir redes gênicas seguindo o modelo de Redes Gênicas Probabilísticas (PGN). A caixa em azul clara (a) representa a entrada (dados de expressão gênica), e a caixa amarela (f) representa a rede PGN inferida. . . . . . . . . . . .

12 Exemplo de um conjunto de dados de expressão gênica: (a) matriz original: para cada linha os valores de expressão do gene e cada coluna uma amostra temporal; (b) dados de expressão quantizados em dois níveis (binário) . . . . . . . . . . . . . . . . . . .

13 Três exemplos com diferentes números de subconjuntos para o gene alvo $Y$ : (a) o melhor subconjunto preditor $\left\{x_{1}, x_{2}, x_{3}\right\}$; (b) dois subconjuntos de preditores $\left\{\left\{x_{1}, x_{2}, x_{3}\right\},\left\{x_{4}\right\}\right\}$; (c) três subconjuntos de preditores $\left\{\left\{x_{1}, x_{2}, x_{3}\right\},\left\{x_{4}\right\},\left\{x_{5}, x_{6}\right\}\right\}$. As arestas representam os valores da função critério atribuídos aos subconjuntos preditores em relação ao gene alvo. . . . . . . . . . . . . . .

14 Ilustração do conceito de predição intrinsecamente multivariada para o caso de 3 preditores e 1 alvo: (a) Preditores tomados isoladamente não predizem o comportamento do alvo; (b) Preditores tomados aos pares também não realizam uma boa predição; (c) A tripla $\left[g_{1}, g_{2}, g_{3}\right]$ é um excelente preditor de $g_{4}$ (gene alvo). Fonte: (MARTINS-JR, 2008) adaptado. 
15 Histograma da entropia condicional $H(Y \mid x)$ : (a) o histograma da esquerda configura uma situação em que $\mathrm{x}$ é um bom preditor de (Y) porque a massa de probabilidades está bem mais concentrada em $Y=1$ (entropia condicional baixa); (b) a massa de probabilidades está melhor distribuída ao longo das classes, o que faz com que x não seja um bom preditor de Y (entropia condicional alta). Fonte: (MARTINS-JR, 2008) - adaptado. . . . . . . . . . . . . . . .

16 Exemplo de uma tabela de distribuição de probabilidades condicionais (Conditional Probability Distribution - CPD) para um dado subconjunto de genes candidatos a preditores $\left(\mathbf{Z}=\left\{X_{4}, X_{5}, X_{9}\right\} \subseteq \mathbf{X}\right)$ estimada com base nos dados quantizados: (a1) nas linhas os genes e nas colunas as amostras utilizadas para estimar a qualidade de predição de um subconjunto de genes (valores destacados em vermelho) em relação a um determinado alvo (valor destacado em verde), considerando todos os pares de instantes de tempo consecutivos (supondo uma Cadeia de Markov de primeira ordem). Como resultado: (a2) a tabela CPD de um gene alvo dados seus preditores $\left(P\left(Y \mid\left\{X_{4}, X_{5}, X_{9}\right\}\right)\right)$; (b) a partir da tabela $C P D$, é derivada uma função lógica Booleana $(L)$ que minimiza o erro Bayesiano de classificação do alvo no próximo instante de tempo (destacadas em cinza a maior probabilidade para cada linha, fazendo com que os valores de $Y$ mais prováveis componham a função $L$ ). A tabela CPD é avaliada por uma função critério para atribuir a qualidade desse subconjunto em relação ao alvo. . . . . . . .

17 Taxonomia de classificação de algoritmos de agrupamento. Fonte: (FAHAD et al., 2014) - adaptado. . . . . . . . . . . . . . .

18 Exemplo de execução do algoritmo k-means. Fonte: (FONTANA; NALDI, 2009) - adaptado. . . . . . . . . . . . . . .

19 As principais etapas envolvidas no framework GeNICE para inferir redes gênicas seguindo o modelo de Redes Gênicas Probabilísticas (PGN). A caixa em verde (a) representa a entrada de dados (dados de expressão gênica), e a caixa amarela (h) representa a rede PGN inferida como o resultado final. As etapas (d) e (f) de agrupamento e análise multivariada, respectivamente as caixas na cor azul, são as novas etapas introduzidas em relação ao que usualmente era feito anteriormente.

20 Agrupamentos de perfis de expressão gênica com o mesmo padrão (mesma forma do sinal) (AZUAJE; DOPAZO, 2005): (a) distância Euclidiana; (b) correlação absoluta de Pearson. . . . . . . . . . . .

21 Exemplo de uma lista de preditores por gene alvo como resultado do processo da análise multivariada aplicado após busca exaustiva por trios $(p=3) \ldots \ldots \ldots \ldots \ldots \ldots$ 
22 Ilustração da análise multivariada para o caso de 3 preditores e 1 alvo: (a) Preditores tomados isoladamente podem não predizem o comportamento do alvo; (b) Duplas de preditores podem realizar excelente predição; (c) A tripla $\left[g_{1}, g_{2}, g_{3}\right]$ é um bom preditor do gene alvo $g_{4}$. .

23 Construção da PGN: (a) preditores (circulo amarelo) $g_{14}, g_{32}, g_{04}$ do gene alvo (circulo azul) $g_{09}$, (b) preditores $g_{09}, g_{12}$ do gene $g_{06}$, (c) preditores $g_{14}, g_{98}, g_{74}$ do gene $g_{17}$ e (d) merge das redes para os alvos $g_{09}, g_{06}$ e $g_{17} \ldots \ldots \ldots \ldots \ldots \ldots \ldots$

24 GeNICE: a novel framework for Gene Networks Inference by Clustering, Exhaustive search andmultivariate analysis. . . . . . . . . . .

25 Avaliação do framework: (a) visão geral do processo de avaliação; (b) alguns detalhes sobre como obter o perfil de expressão predito de um gene $Y$ no tempo $t_{2}$ baseado no melhor subconjunto de preditores $\mathbf{Z}$ no tempo $t_{1}$. O mesmo raciocínio é aplicado a todos os tempos amostrais consecutivos, para todos os genes e seus respectivos preditores. . . . .

26 Precisão global do framework proposto para $k \in\{20,30,40,50,100\}$ e $N \in\{100,1000\}$, quando comparada à busca exaustiva pura para $N=$ 100 apenas (barras pretas legendadas como "Exaustiva"referem-se à busca exaustiva pura). O retângulo vermelho destaca a busca exaustiva e agrupamento para $N$ e $k=100 \ldots \ldots \ldots \ldots$

27 Distribuição (boxplot) de precisões dos perfis de expressão dos genes para cada tripla $(k, \mathcal{J}, c)$ e dados simulados in silico gerados com $N=5000$ genes. $k \in\{20,30,40,50\} ; \mathcal{J} \in\{$ Informação Mútua (IM), $\mathrm{CoD}\} ; c \in\{$ correlação absoluta de Pearson, distância Euclideana\}. A linha tracejada na cor preta representa a linha de tendência que melhor se ajusta às distribuições. . . . . . . . . . . . . . . .

28 Distribuição (boxplot) de precisões dos perfis de expressão dos genes para cada tripla $(k, \mathcal{J}, c)$ e dados reais de Plasmodium falciparum contendo 5080 genes $(N=5080) . k \in\{20,30,40,50\} ; \mathcal{J} \in\{$ Informação Mútua (IM), CoD $\} ; c \in\{$ correlação absoluta de Pearson, distância Eu-

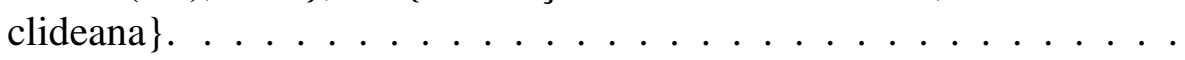

29 PGN inferida para as sementes glicolíticas (nós amarelos) e apicoplastos (nós verdes) para $k=50$, correlação absoluta de Pearson e CoD. Os nós brancos indicam genes preditores que não são sementes. Visualização gerada no Cytoscape (SHANNON et al., 2003). . . . . . . . .

30 PGN inferida para as sementes glicolíticas (nós amarelos) e apicoplastos (nós verdes), usando correlação absoluta de Pearson como critério de agrupamento, informação mútua como função critério para seleção de características, e 100 agrupamentos $(k=100)$. Os nós brancos indicam genes preditores que não são sementes. Visualização de rede gerada no Cytoscape (SHANNON et al., 2003). . . . . . . . . . . . 
31 PGN inferida para as sementes glicolíticas (nós amarelos) e apicoplastos (nós verdes), usando correlação absoluta de Pearson como critério de agrupamento e CoD como função critério para seleção de características, e 100 agrupamentos $(k=100)$. Os nós brancos indicam genes preditores que não são sementes. Visualização de rede gerada no Cytoscape (SHANNON et al., 2003). . . . . . . . . . . . . 64

32 Distribuições de graus na escala normal para as redes apresentadas nas Figuras 29 (painel a), 30 (painel c) e 31 (painel e). Nos painéis (b) (d) e (f) seus respectivos gráficos na escala log-log. . . . . . . . . . .

33 Sinais de expressão dos genes presentes em cada um dos $k=50$ agrupamentos baseados no conjunto de dados do Plasmodium falciparum: (a) distância Euclideana; (b) correlação absoluta de Pearson. Os sinais na cor rosa representam os respectivos sinais de expressão dos genes

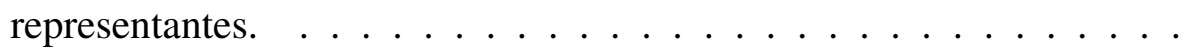




\section{Lista de Tabelas}

1 Código genético . . . . . . . . . . . . . . . 16

2 Exemplo de tabela contendo as probabilidades condicionais de um gene de uma PBN. . . . . . . . . . . . . . . . . . . . . .

3 Genes sementes da via glicolítica e do apicoplasto foram considerados no experimento envolvendo dados do Plasmodium falciparum. . . . . 54

4 Tempo de processamento (minutos) para a Informação Mútua (IM) e Coeficiente de Determinação $(\mathrm{CoD})$ como funções critério, considerando um gene alvo. . . . . . . . . . . . . . . . . . . . . .

5 Quantidades de nós e de arestas para as redes com o melhor subconjunto preditor para cada uma das 10 sementes glicolíticas e 27 sementes de apicoplastos e as correspondentes intersecções (número de preditores que predizem sementes de ambos os módulos). . . . . . . . .

$6 \quad$ Números de nós e de arestas para as redes com o melhor subconjunto de preditores para cada uma das 10 sementes glicolíticas e 27 sementes de apicoplasto e as correspondentes intersecções (número de preditores de sementes de ambos os módulos) para a correlação absoluta de Pearson como função critério, para as duas funções critério (CoD e Informação Mútua), e número de agrupamentos $k=100$. 


\title{
Lista de Abreviaturas e Siglas
}

\author{
cDNA DNA complementar (complementary DNA) \\ SAGE Análise Serial da Expressão Gênica (Serial Analysis of Gene Expression) \\ RNA Ácido Ribonucleico (RiboNucleic Acid) \\ mRNA RNA Mensageiro (Messenger RNA) \\ FT Fator de Transcrição \\ GRN Rede de Regulação Gênica (Gene Regulatory Network) \\ RB Redes Bayesianas (Bayesian Networks) \\ PBN Rede Booleana Probabilística (Probabilistic Boolean Network) \\ PGN Rede Gênica Probabilística (Probabilistic Genetic Network) \\ BN Rede Booleana (Boolean Network). \\ IMP Predição Intrinsecamente Multivariada \\ (Intrinsically Multivariate Prediction) \\ IS Pontuação da predição intrinsecamente multivariada \\ CoD Coeficiente de Determinação \\ IM Informação Mútua \\ SSE Soma dos quadrados dos erros do $k$-ésimo agrupamento \\ (Sum of Squares Error) \\ BIC Critério de Informação Bayesiana \\ (Bayesian Information Criterion) \\ AIC Critério de Informação Akaike \\ (Akaike Information Criterion) \\ DREAM Diálogo para Avaliações de Métodos de Engenharia Reversa \\ (Dialogue for Reverse Engineering Assessments and Methods) \\ IDC Ciclo de Desenvolvimento Intraeritrocítico \\ (Intraerythrocytic Developmental Cycle)
}




\title{
Lista de Símbolos
}

\author{
$C A_{i} \quad$ Coeficiente de Agrupamento do $i$-ésimo nó \\ $k_{i} \quad$ Grau de ligações do $i$-ésimo nó \\ $a_{j k} \quad$ Número de conexões entre nós vizinhos \\ $p(k) \quad$ Probabilidade da ocorrência de vértices com grau $k$ \\ 5' Carbono (pentose) ligado no fosfato \\ 3' Carbono (pentose) ligado na hidroxila \\ $\mathrm{G} \quad$ Conjunto de genes \\ $\psi \quad$ Função de Transição Booleana \\ $\Psi \quad$ Conjunto de Funções de Transições Booleanas \\ $l(i) \quad$ Número de funções de transição associadas ao gene $i$ \\ $c_{i}^{(i)} \quad$ Probabilidade associada a $l(i)$ \\ $v \quad$ Possíveis vetores de funções Booleana \\ $P(Y \mid \mathbf{Z}) \quad$ Probabilidade condicional de $Y$ dado que $\mathrm{Z}$ foi observado \\ $\mathbf{Z} \quad$ Conjunto de genes candidatos a preditores \\ $Y \quad$ Gene alvo \\ $\mathcal{J}$ (.) Função critério escolhida que avalia a dependência de $Y$ em relação $\mathbf{Z}$ \\ $\mathbf{Z}^{\prime} \quad$ Subconjunto de $\mathbf{Z}$ \\ $\varepsilon_{Y} \quad$ Erro ao prever $Y$ na ausência de outras observações \\ $\operatorname{IM}(\mathbf{Z}, \mathrm{Y}) \quad$ Informação mútua entre $Z$ e $Y$ \\ $H(Y) \quad$ Entropia de $Y$ \\ $H(Y \mid \mathbf{Z}) \quad$ Entropia condicional média de $Y$ dado que $\mathbf{Z}$ foi observado
}




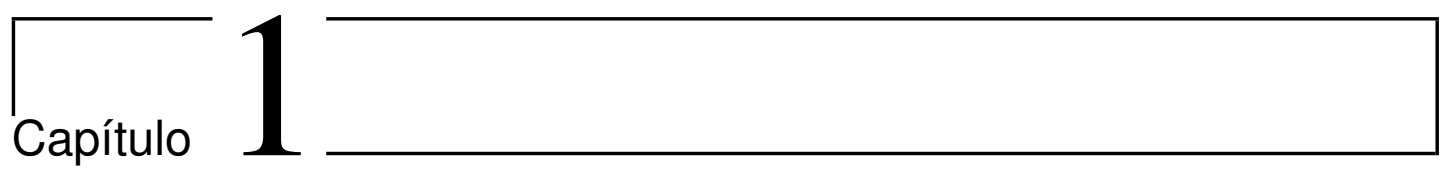

\section{Introdução}

Um organismo vivo é um sistema biológico complexo que pode ser interpretado como uma rede de moléculas conectadas por reações químicas e seus mecanismos reguladores. A biologia sistêmica é um campo científico emergente que visa a modelagem computacional e matemática de tais sistemas biológicos complexos. Um dos principais objetivos em biologia sistêmica é revelar como os genes e seus produtos interagem para a regulação dos processos celulares, através dos estudos das interações entre os componentes dos sistemas biológicos e como essas interações originam a função e o comportamento desse sistema. Para isso faz-se necessária a reconstrução das redes de regulação gênica (Gene Regulatory Network - GRN) (PINDAH et al., 2015). A modelagem, a inferência e a interpretação de GRNs a partir de dados de expressão gênica temporal vem atraindo uma atenção significativa, particularmente após o desenvolvimento de técnicas de medição de expressão gênica em larga escala, tais como microarranjos (microarrays) de cDNA (SHALON; SMITH; BROWN, 1996), SAGE (VELCULESCU et al., 1995) e, mais recentemente, RNA-seq (WANG; GERSTEIN; SNYDER, 2009).

\subsection{Contexto e justificativa}

O problema de inferência de GRNs envolve a descoberta de relações reguladoras complexas entre moléculas que podem descrever diversas funções biológicas e também a dinâmica de atividades moleculares. Uma vez que a rede é recuperada, estudos de intervenção podem ser conduzidos para controlar a dinâmica de sistemas biológicos visando prevenir ou tratar doenças (SHMULEVICH; DOUGHERTY, 2014). Genes e proteínas geralmente formam uma intrincada rede complexa onde muitas vezes o com- 
portamento de um determinado gene, medido por meio de seu nível de expressão (ou seja, a abundância de mRNA), depende de uma ação multivariada e coordenada de outros genes e seus subprodutos (MARTINS-JR et al., 2008). Assim, a inferência de GRNs baseada na análise de dados de expressão gênica requer métodos e algoritmos robustos, e novas abordagens estão constantemente sob avaliação. A importância da reconstrução de GRNs também pode ser vista através de muitas iniciativas, como o projeto DREAM (Dialogue for Reverse Engineering Assessments and Methods) (MARBACH et al., 2012).

Para a modelagem de interação gênica existem duas abordagens principais (SHMULEVICH; DOUGHERTY, 2014). Uma abordagem contínua, que visa a obtenção de um modelo quantitativo detalhado de redes bioquímicas (DE-JONG, 2002; HECKER et al., 2009). E a outra são os modelos discretos, que avaliam as interações gênicas de um ponto de vista qualitativo, visando identificar o comportamento dos sistemas de forma macro, abstraindo-se de detalhes biológicos, tais como as redes Booleanas e suas variantes estocásticas: Redes Booleanas Probabilísticas (PBN) (SHMULEVICH et al., 2002) e as Redes Gênicas Probabilísticas (PGN), que é um modelo PBN com algumas restrições (BARRERA et al., 2007).

A modelagem discreta tem sido aplicada com êxito na análise e simulação de várias redes biológicas, tais como as da Drosophila melanogaster (SÁNCHEZ; THIEFFRY, 2001; ALBERT; OTHMER, 2003), ciclos celulares da levedura (LI et al., 2004; ZHANG et al., 2006; DAVIDICH; BORNHOLDT, 2008), Arabidopsis thaliana (ESPINOSA-SOTO; PADILLA-LONGORIA; ALVAREZ-BUYLLA, 2004), de mamíferos (FAURE et al., 2006) e do Plasmodium falciparum (BARRERA et al., 2007).

A definição dos parâmetros para inferir redes de regulação gênica por meio de modelos computacionais e estatísticos ainda é uma área que encontra-se em desenvolvimento. Este problema é ainda mais desafiador devido ao número limitado de amostras, a enorme dimensionalidade de genes, e a presença de variações indesejadas (denominadas como ruídos ou pertubações sistemáticas) inerente ao processo e que acabam sendo incorporadas durante a obtenção dos dados de expressão gênica (HECKER et al., 2009; SHMULEVICH; DOUGHERTY, 2014).

Atualmente, existe uma extensa literatura que aborda este problema de inferência de GRNs (MARKOWETZ; SPANG, 2007; BANSAL et al., 2007; HECKER et al., 2009; DE-SMET; MARCHAL, 2010; MARBACH et al., 2012). Alguns métodos que lidam com este problema englobam seleção de características ${ }^{1}$ como os baseados

\footnotetext{
${ }^{1}$ Neste trabalho, a menos que observado de outra forma, o termo características refere-se a Atributos, do inglês: Features, aplicado no contexto computacional.
} 
em entropia, ou por máxima relevância e mínima redundância (MEYER et al., 2007; HIRA; GILLIES, 2015), perturbação de sinal (IDEKER; THORSSON; KARP, 2000; CARASTAN-SANTOS et al., 2017), entre outros.

Os modelos discretos, como as PGNs são adequados, pois o número de amostras geralmente é da ordem de dezenas e o número de genes é da ordem de milhares, como é o caso nos dados de expressão gênica. A principal inconveniência destes modelos é a perda de informação como decorrência do processo de quantificação neste dados. No entanto, esse processo torna os modelos mais simples de implementar e analisar, e muitos métodos discretos têm sido propostos para modelar GRNs, por exemplo, (LAHDESMAKI; SHMULEVICH, 2003; LIANG; FUHRMANE; SOMOGYI, 1998; NAM; SEO; KIM, 2006).

Mesmo que os genes sejam limitados a dois possíveis valores de expressão em um modelo PBN, inferir uma rede ainda é uma tarefa complexa devido a maldição da dimensionalidade (BELLMAN; DREYFUS, 2015). Entretanto, o modelo de PGN simplifica a inferência de uma rede por seleção local de características em busca dos melhores preditores de genes que predizem o comportamento de um determinado gene de estudo (BARRERA et al., 2007). Como a busca exaustiva é o único algoritmo de seleção de características que garante otimalidade, implementações computacionais de alto desempenho são necessários para definir grupos de preditores com apenas três ou quatro dimensões (para dimensões maiores, a busca exaustiva se torna inviável mesmo para implementações desse tipo) (BORELLI et al., 2013; CARASTAN-SANTOS et al., 2017). Uma alternativa para reduzir a complexidade computacional da busca exaustiva é aplicar alguma técnica de redução de dimensionalidade para restringir o espaço de busca dos subconjuntos de preditores candidatos para um dado gene alvo. No entanto, isso não é trivial, já que genes individualmente podem ser bons quando combinados para predizer o comportamento de outro gene (alvo). Do mesmo modo, as melhores genes individuais podem não ser tão bons em predizer o alvo quando combinadas entre si (PUDIL; NOVOVICOVÁ; KITTLER, 1994; MARTINS-JR et al., 2008).

\subsection{Objetivos e contribuições}

O principal objetivo desta tese foi o desenvolvimento de um novo arcabouço para inferência de GRNs modeladas como PGNs que aplica agrupamento de forma a reduzir o espaço de busca de genes candidatos para seleção dos melhores candidatos a preditores de um determinado gene alvo (JACOMINI et al., 2016; JACOMINI et al., 
2017). Nesse sentido, tal arcabouço efetivamente alivia a maldição da dimensionalidade inerente do problema de inferência de GRNs e, consequentemente, seu custo computacional. Tal arcabouço foi denominado GeNICE - Gene Networks Inference by Clustering, Exhaustive search and multivariate analysis (JACOMINI et al., 2017).

O GeNICE executa uma seleção de características local para cada gene alvo para obter os melhores subconjuntos de candidatos a preditores. Porém, apenas os genes representantes do agrupamento aplicado na etapa anterior a de seleção de características se tornam candidatos a preditores, justamente o que faz com que a dimensionalidade diminua consideravelmente (equivalente ao número de grupos gerados pelo agrupamento). Além disso, uma análise de predição intrinsecamente multivariada é conduzida para eliminar características redundantes de cada subconjunto preditor (MARTINS-JR et al., 2008), consequentemente, simplificando a rede de forma a obter uma rede gênica mínima.

Resultados experimentais adotando os dados gerados pelo SysGenSIM (PINNA et al., 2011), usados no desafio DREAM 5 (MARBACH et al., 2012), mostram que os perfis de expressão (dinâmica) produzidos pela lógica de erro mínimo de classificação dos subconjuntos preditores selecionados em relação aos genes alvos são geralmente muito próximos dos perfis de expressão originais desses alvos (cerca de $90 \%$ de identidade).

Além disso, experimentos usando dados de microarrays temporais de Plasmodium falciparum (um agente da malária) obtiveram precisões ainda mais altas (97\% em média). Com relação a este mesmo conjunto de dados de malária, foi realizada uma análise topológica, mostrando componentes conectados para as funções de glicólise e apicoplasto com apenas um subconjunto preditor para cada gene semente desses dois módulos funcionais. A estrutura topológica recuperada em torno das sementes consideradas exibiu propriedades de redes mundo pequeno (small-world) e redes livre de escala (scale-free), que são comumente observadas em redes biológicas (STROGATZ, 2001; BARABÁSI; OLTVAI, 2004).

De fato, o método mostrou grande eficiência computacional para inferência de redes e, ao mesmo tempo, tais redes produziram perfis de expressão e topologias tão boas ou até melhores do que aquelas geradas pelas redes inferidas pelo mesmo processo sem envolvimento de agrupamento e análise de predição intrinsecamente multivariada para remoção de características redundantes como etapas inicial e final, respectivamente. 


\subsection{Organização do texto}

Esta tese apresenta outros cinco capítulos organizados da seguinte forma:

Capítulo 2: Fornece uma fundamentação de biologia sistêmica relevante para uma melhor compreensão e motivação do problema tratado nesta tese. São apresentados os principais conceitos biológicos envolvidos nos processos de expressão gênica e regulação de genes, em particular os mecanismos de regulação transcricional e pós-transcricional, bem como as características típicas dos dados de expressão gênica adotados para inferência de GRNs. Além disso, apresenta conceitos relativos a técnicas de agrupamento, de seleção de características, predição intrinsecamente multivariada, e teoria de redes complexas, bem como os principais modelos de GRNs (com ênfase nas BNs, PBNs e PGNs), descrevendo ainda algumas abordagens tipicamente aplicadas para lidar com o problema da inferência de GRNs.

Capítulo 3: Descrição do arcabouço proposto para inferência de redes gênicas com detalhes relacionados à metodologia e o funcionamento desta proposta, a fim de demonstrar um processo de aprendizagem (engenharia reversa) para reconstruir a estrutura das redes de regulação gênicas baseado em agrupamento.

Capítulo 4: Detalhes da montagem do experimentos, além das discussões e critérios de avaliação adotados para avaliar o desempenho das redes inferidas.

Capítulo 5: Apresenta e discute os resultados experimentais obtidos das redes inferidas pelo arcabouço proposto tanto para dados sintéticos de expressão gênica como para dados reais de Plasmodium falciparum (agente causador da malária).

Capítulo 6: Conclusão da tese, incluindo um delineamento e orientações para pesquisas futuras (Seção 6.1). 


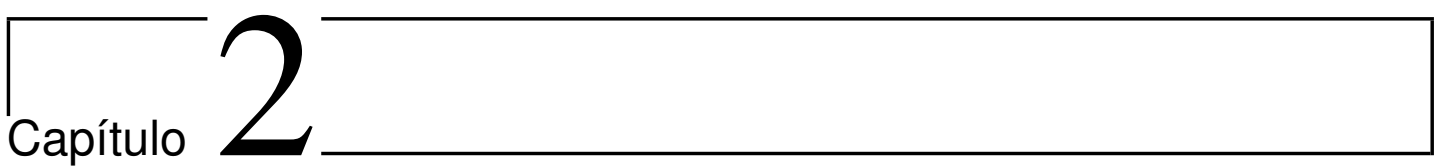

\section{Fundamentação teórica}

Este capítulo tem como objetivo uma revisão dos fundamentos mencionados nesta tese; como esses conceitos se relacionam e as consequências dessas relações. Consideramos tais fundamentos necessários para a compreensão deste trabalho. Estes conteúdos não foram desenvolvidos nesta pesquisa, no entanto, cada um deles foi utilizado ou mencionado de alguma forma.

\subsection{Fundamentos de Sistemas Complexos}

Quando as propriedades de um sistema não são consequências naturais de seus elementos constituintes vistos de forma isolada, sendo capazes de interagir entre si e com o meio ambiente, dizemos então que este é um sistema complexo. Pode ser composto por várias partes que interagem e têm a habilidade de gerar novas qualidades no comportamento do grupo (rede) através de sua auto-organização. Como esses sistemas são formados por partes discretas que se conectam, é necessário adotar um tipo de representação para estudá-los, e a modelagem por redes (ou grafos) passa a ser realizada de forma natural (BAR-YAM, 1997). Tais sistemas possuem diversas propriedades, destacando-se:

- Emergência: Ao invés de serem planejados ou controlados, os agentes do sistema interagem de maneira aparentemente aleatória. De todos esses padrões de interação, emerge o comportamento dos agentes dentro do sistema e o comportamento do sistema em si. Por exemplo, um formigueiro possui um labirinto de passagens de interconexões, grandes cavernas, túneis de ventilação e muito mais. E no entanto não houve nenhum grande plano para a construção de sua arquitetura. 
- Conectividade: As formas em que os agentes em uma rede de relacionamentos interagem é fundamental para a sobrevivência do sistema, pois é a partir das conexões que os padrões são formados e as mensagens divulgadas. As relações entre os agentes são geralmente mais importantes do que os próprios agentes.

- Auto-organização: Não existe uma hierarquia de comando e controle em um sistema complexo adaptativo, nenhum planejamento ou gestão, mas há uma constante reorganização para encontrar o melhor ajuste para o ambiente. $\mathrm{O}$ sistema é auto-organizado através do processo de emergência e retroalimentação $(\text { feedback })^{1}$.

- Universalidade: Sistemas pertencentes à mesma classe possuem propriedades semelhantes.

Como exemplo de sistemas complexos temos: as conexões entre aeroportos, definidas por rotas aéreas; as malhas rodoviárias, formadas por rodovias que interligam cidades; as redes sociais, formadas por pessoas que estão ligadas por laços familiares, amizades e/ou políticos; a internet composta de servidores conectados por roteadores e ligados por fibras óticas; os cientistas que estão conectados de acordo com seus trabalhos produzidos em coautoria; e o genoma, a partir do qual são gerados fenótipos, os quais nos tornam seres únicos (HOLDEN, 2005).

\subsection{Breve histórico sobre Teoria dos Grafos e Redes Complexas}

Barabási (2014a) descreve que em 1736 Leonhard Euler propusera uma rigorosa demonstração matemática da solução de um quebra-cabeças jamais resolvido, esse apresentado na Figura 1: "Pode-se cruzar as sete pontes de Königsberg sem jamais passar pela mesma ponte duas vezes ?". Ele não só resolveu o problema como acabou desbravando um ramo da matemática chamado de teoria dos grafos, o qual estuda as propriedades das relações entre pares de elementos em uma estrutura de rede.

Para tanto Euler utilizou vértices para representar cada um das quatro faixas de terra separadas pelo rio, distinguindo-as com as letras A, B, C e D. Em seguida, definiu que as pontes em seu modelo seriam chamadas de arestas e conectou aqueles trechos de terras interligados por pontes. Euler então, obteve um grafo cujo vértices eram as faixas de terra e as arestas as pontes. Em sua demonstração, vértices que possuem

\footnotetext{
${ }^{1}$ Uma resposta ou reação do sistema à mensagem enviada.
} 


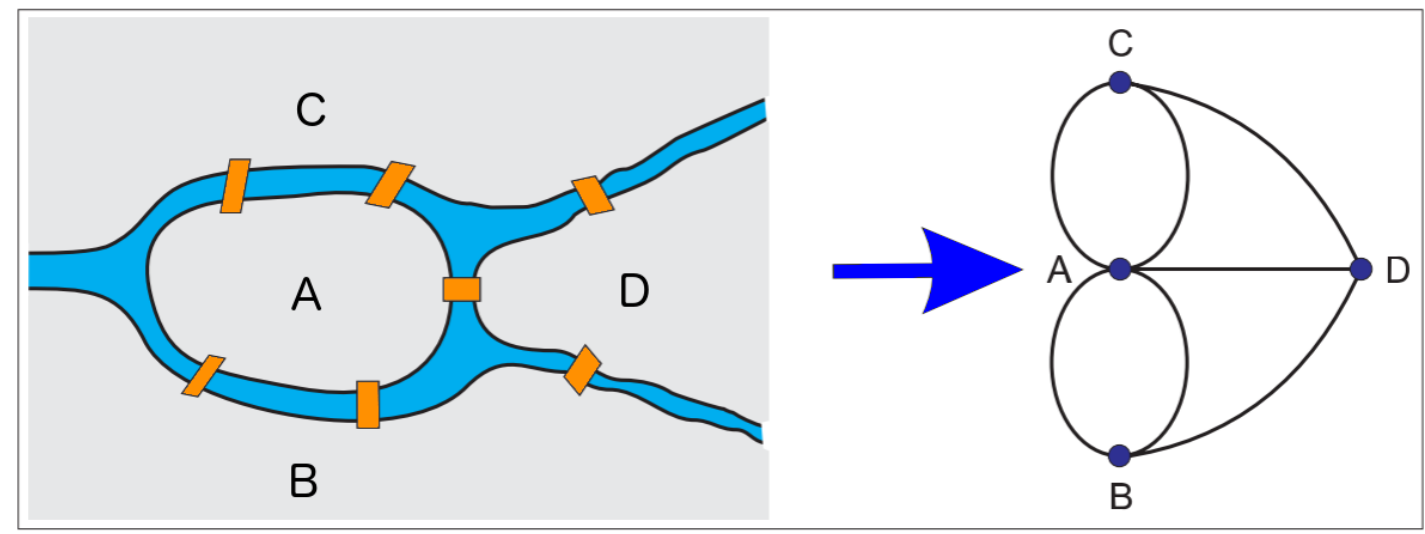

Figura 1. À esquerda: a Ponte Königsberg antes de 1875 com a ilha Kneiphof (A) e a faixa de terra (D) entre duas vertentes do rio Pregel (C e B). À direita: sua representação em forma de grafo. Fonte: (BARABÁSI, 2014a, p. 10) adaptado.

números ímpares de arestas devem ser o ponto de partida ou de chegada do percurso. Um passeio que atravessa todas as pontes só poderia ter um único ponto de partida e um único ponto de chegada. Esse caminho só pode existir em um grafo que tenha zero ou dois vértices com um número ímpar de arestas. Como o grafo de Königsberg possuía quatro vértices com número ímpar de arestas, não era possível encontrar o caminho desejado. Posteriormente, em 1875, foi construída uma ponte ligando os vértices B e $\mathrm{C}$, tornando somente os vértices $\mathrm{A}$ e D com número ímpar de arestas.

A teoria dos grafos desenvolveu-se bastante após Euler, com contribuições feitas por Cauhy, Hamilton, Cayley, entre outros. Em Krackhardt and Carley (1998) foi introduzida a ideia de uma meta-rede, com o modelo de PCANS, os autores sugerem que "todas as organizações são estruturadas ao longo destes três domínios, pessoas, tarefas e recursos". Seu estudo introduz o conceito de que as redes ocorrem em vários domínios e que os mesmos são inter-relacionados. Este campo tem crescido em outro ramo da Ciência das Redes, chamado Análise de Redes Dinâmicas (BARABÁSI; OLTVAI, 2004; BARABÁSI, 2014a; BOCCALETTI et al., 2006).

A teoria probabilística na ciência das redes foi desenvolvida por Erdös and Rényi (1970). A partir daí, pesquisadores vêm se dedicando ao estudo das redes e seus impactos na sociedade. Por exemplo, considerando os artigos científicos, teses e dissertações orientados pelos autores, por seus discípulos, e pelos discípulos de seus discípulos, forma-se a rede de Influência de Paul, e as distâncias entre quaisquer autores ou coautores relativas ao conector principal puderam ser medidas, dando origem ao denominado número (distância) de Erdös. Essa medida se aplica a qualquer tipo de rede, podendo ser utilizada como um modelo de crescimento das redes independentemente de sua natureza. Essa constatação científica permitiu o enorme avanço do estudo das 
redes, e o modelo encontra aplicações como a Internet, permitindo a otimização de fluxo de dados, localização de roteadores, entre outras.

Trabalhos recentes oriundos da ciência das redes visam descrever matematicamente topologias diferentes de redes. Watts and Strogatz (1998) criou um modelo de redes chamado mundo pequeno (small-world), enquanto Barabási and Albert (1999) desenvolveram o modelo de redes livres de escala (scale-free), denominado Barabási-Albert (BA). Tais redes contêm poucos vértices com um número de conexões (grau) bem acima da média $(h u b s)^{2}$, e crescem através da inclusão de novos vértices no decorrer do tempo, e esses novos vértices se ligam aos vértices já existentes na rede com probabilidade proporcional ao grau. Com esse modelo é possível gerar redes com distribuição de grau do tipo lei de potência, propriedade amplamente observada em vários sistemas naturais e artificiais, incluindo a internet, redes de citação e redes sociais. Tanto os modelos de redes mundo pequeno quando as redes livres de escala são observadas nas redes estudadas neste trabalho (redes gênicas) (WATTS, 1999; ALBERT; BARABÁSI, 2002; NOORT; SNEL; HUYNEN, 2004; HEIN; SCHWIND; KÖNIG, 2006; CLAUSET; SHALIZI; NEWMAN, 2009).

\subsubsection{Fundamentos de Redes Complexas}

De acordo com Costa et al. (2007) uma rede complexa estende o formalismo da teoria dos grafos por acrescentar medidas e métodos fundamentados em propriedades reais de um sistema complexo (Seção 2.1). Esta extensão se concentra principalmente na interpretação de que o objetivo das redes é a representação de sistemas reais, por meio da análise de dados experimentais, considerando que as redes são dinâmicas, podendo modificar sua estrutura ao longo do tempo (auto-organização). Elas apresentam topologias e propriedades distintas e bem definidas, as quais podem ser usadas para representar uma rede gênica, bem como caracterizá-la em termos de medidas de redes complexas.

As aplicações que utilizam a teoria de redes complexas em modelagem de sistemas naturais e artificiais podem ser encontradas em diversos trabalhos. Através da abordagem de biologia sistêmica (systems biology). Em Barabási, Gulbahce and Loscalzo (2011) verifica-se que muitos componentes estão conectados através de relações complicadas, mas que são organizados por princípios simples. Usando a teoria de redes, representando sistemas como redes complexas, onde os vértices representam fatores biológicos (biomoléculas, doenças, fenótipos, etc.) e as ligações representam suas relações (interações físicas, via metabólica compartilhada, gene compartilhado, traço

\footnotetext{
${ }^{2}$ Segue a lei de Pareto 80/20: Muitos vértices com grau pequeno, e poucos com grau muito grande.
} 
compartilhado, etc.), foram observados os princípios da medicina de redes (network medicine) (BARABÁSI; GULBAHCE; LOSCALZO, 2011). Em resumo, tais princípios enunciam que as redes são classificadas como livres de escala e mundo pequeno, além de formarem módulos (comunidades) funcionais (LOSCALZO; BARABÁSI, 2011).

Em um modelo de redes gênicas, eliminar um vértice (gene) que participa de um processo regulatório de algum fenômeno biológico pode afetar o sistema biológico de diferentes formas e em diversas escalas, ou mesmo não afetá-lo (o efeito de uma alteração na rede pode não ser proporcional à alteração em si). Por isso, validar um modelo que represente uma estrutura real das relações de um sistema da regulação gênica ainda é um processo complexo.

Caracterizar e inferir essas redes, principalmente as de regulação gênica, ainda é um ponto que necessita de mais investigações. Alguns autores utilizam uma abordagem matemática, outros tentam identificar as relações entre os componentes da rede usando uma abordagem estatística, e outros tentam aplicar métricas e classificá-las usando seleção de características (STROGATZ, 2001; ALBERT; BARABÁSI, 2002; NEWMAN, 2003; AMARAL; OTTINO, 2004; BOCCALETTI et al., 2006; COSTA et al., 2007; SAEYS; INZA; LARRAÑAGA, 2007; BARRERA et al., 2007; MARTINSJR et al., 2008; HECKER et al., 2009; SNIJDERS, 2011; LOPES; JR; COSTA, 2011; MENDOZA, 2014; LOPES et al., 2014).

\subsubsection{Redes Aleatórias de Erdös-Rényi}

A Ciência das Redes visa construir modelos que reproduzem as propriedades de redes reais. A maioria das redes reais a primeira vista parecem ter sido geradas de forma puramente aleatória, conforme o modelo da geração de redes aleatórias proposto por Erdös and Rényi (1959). Esse modelo inicia com $N$ vértices desconectados e assume uma probabilidade $p$ para a existência de uma aresta como parâmetro. Assim, executa-se um experimento de Bernoulli para cada par de vértices, sorteando um valor aleatório com distribuição uniforme entre 0 e 1 . Caso esse valor seja maior ou igual a $p$ para um dado par de vértices, adiciona-se uma aresta entre eles. Caso contrário, esse par permanece desconectado.

A distribuição dos graus dos nós de uma rede aleatória do tipo Erdös-Rényi tende a seguir uma Poisson conforme Figura 2. Nesse sentido, a maioria dos nós tendem a possuir um grau parecido (próximo da média). Entretanto, esse tipo de rede aleatória não reflete adequadamente muitas redes reais como a internet, redes sociais e redes bi- 
ológicas. Nessas redes, os graus dos nós podem variar muito mais, além de propensão muito maior em formar comunidades (módulos). A seguir serão brevemente discutidos dois modelos que refletem melhor a topologia dessas redes: mundo pequeno e livre de escala.

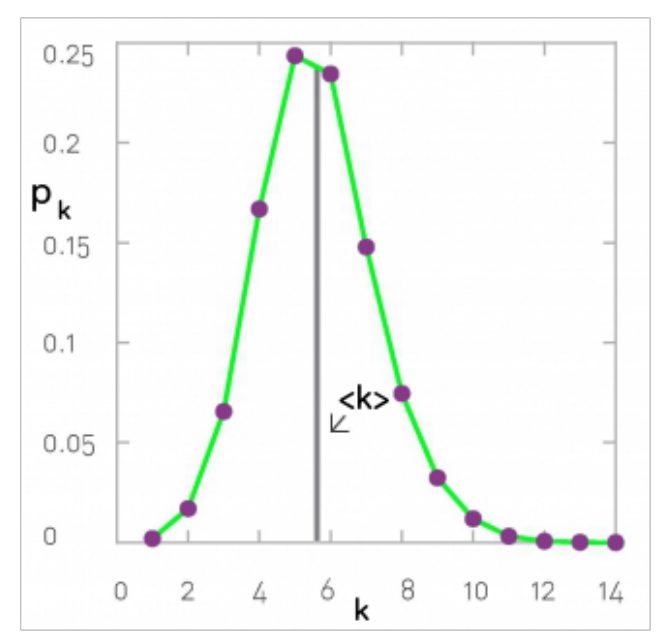

Figura 2. A forma exata da distribuição de graus de uma rede aleatória é a distribuição de Poisson. A linha vertical cinza mostra o grau médio $<k>=5$, 61. Fonte: (BARABÁSI, 2014b) adaptado.

\subsubsection{Redes Mundo Pequeno}

O modelo de rede do tipo mundo pequeno (small-world), proposto por Watts and Strogatz (1998), é um tipo de grafo em que grande parte dos vértices encontram-se a uma pequena distância uma das outras e, além disso, os vértices tendem a se agrupar resultando em uma proporção alta de triângulos (muito mais alta do que a esperada em um modelo aleatório do tipo Erdös-Rényi). Este modelo representa uma alternativa ao modelo aleatório, assumindo como hipótese que as redes biológicas, tecnológicas e sociais podem apresentar uma topologia que não é totalmente aleatória (NOORT; SNEL; HUYNEN, 2004).

As redes mundo pequeno apresentam agrupamentos locais e um diâmetro (maior caminho mínimo, ou geodésico, entre dois vértices) pequeno. O agrupamento local em torno de um nó pode ser medido pelo coeficiente de agrupamento $\left(C A_{i}\right)$ dado pela Equação:

$$
C A_{i}=\frac{\left|\left\{a_{j k}\right\}\right|}{k_{i}\left(k_{i}-1\right)}: v_{j}, v_{k} \in N_{u}, a_{j k} \in A
$$

em que $k_{i}$ é o grau de ligações do $i$-ésimo nó, $a_{j k}$ é o número máximo de conexões 
da vizinhança $(N)$ para um grafo direcionado (Grafo $=(V, A), V=$ vértices (nós) e $A=$ arestas) (WATTS; STROGATZ, 1998). Em outras palavras, quanto mais triângulos existirem em torno de um nó, maior é o seu agrupamento. Assim, o agrupamento da rede pode ser medido pela média dos agrupamentos dos nós. Existem outras definições de agrupamento, porém todas elas consistem em medir a proporção de triângulos na rede.

O modelo apresenta as principais características apresentadas no estudo de Travers and Milgram (1967), já que tende a apresentar núcleos locais de amizade (forte agrupamento com alta proporção de triângulos) interligados por algumas poucas conexões (conexões de "longo alcance"), o que faz com que as pessoas estejam a poucos graus de separação umas das outras. De fato, a distância média entre os vértices de uma rede muito grande não ultrapassa um pequeno número de vértices. Para isso ocorrer, basta que algumas ligações aleatórias entre os grupos sejam estabelecidas. Em larga escala, bastam poucas ligações (conexões de "longo alcance") entre os grupos para fazer com que a rede se torne um "mundo pequeno". É a partir desses fundamentos que se consegue difundir vírus e informações, como boatos, em larga escala rapidamente.

Redes do tipo mundo pequeno são encontradas em muitas situações do mundo real, tais como: cadeias alimentares, redes de energia elétrica, redes metabólicas, redes de neurônios, redes de eleitores, grafos de chamadas telefônicas e redes de amizade.

\subsubsection{Redes Livres de Escala}

As redes livres de escala são redes complexas cujo grau de distribuição segue uma lei de potência, em que a maioria dos vértices (nós) tem poucas ligações, contrastando com a existência de alguns vértices que apresentam um elevado número de ligações. Barabási (2009) demonstrou que essas redes não são formadas de modo puramente aleatório, existindo uma ordem na dinâmica de estruturação das redes, ou seja, quanto mais ligações um nó apresenta, maior a chance desse nó formar novas conexões no futuro. Tal característica é denominada conexão preferencial: um novo nó tende a ligar-se a um nó existente com mais ligações, resultando no fenômeno "rico fica mais rico".

A probabilidade de um nó se conectar a outro é diretamente proporcional ao número de conexões que o nó escolhido possui. Isto implica que essas redes não são constituídas por vértices com probabilidades iguais de terem o mesmo número de ligações, havendo sim, um conjunto pequeno de vértices altamente conectados e uma maioria de vértices com poucas ligações. Deste modo as redes livres de escala são do- 
minadas por um número relativamente pequeno de vértices, designados de conectores (hubs). Além da conexão preferencial de um vértice a vértices com mais conexões, a rede está continuamente em expansão (crescimento). Em cada novo passo dinamicamente é adicionado um nó que se conecta aos vértices já existentes na rede via conexão preferencial, como se alguns vértices atraíssem mais do que outros de acordo com os seus graus. Esse modelo que combina a conexão preferencial e o crescimento foi a primeira tentativa bem-sucedida de Barabási (2009) em explicar a existência de hubs.

As redes livres de escala são mais resistentes a falhas acidentais, porém mais vulneráveis a ataques inteligentes (ataques direcionados aos $h u b s$ ). Nestas redes a probabilidade de um nó ter $k$ ligações decai quando $k$ aumenta, seguindo a lei de potência (Figura 3b) Equação 3.

$$
P(k) \sim k^{-\gamma}
$$

em que $k>0$ e $\gamma>0$. O parâmetro $\gamma$ é um expoente livre de escala e determina a probabilidade $p(k)$ da ocorrência de vértices com grau $k$ na rede.

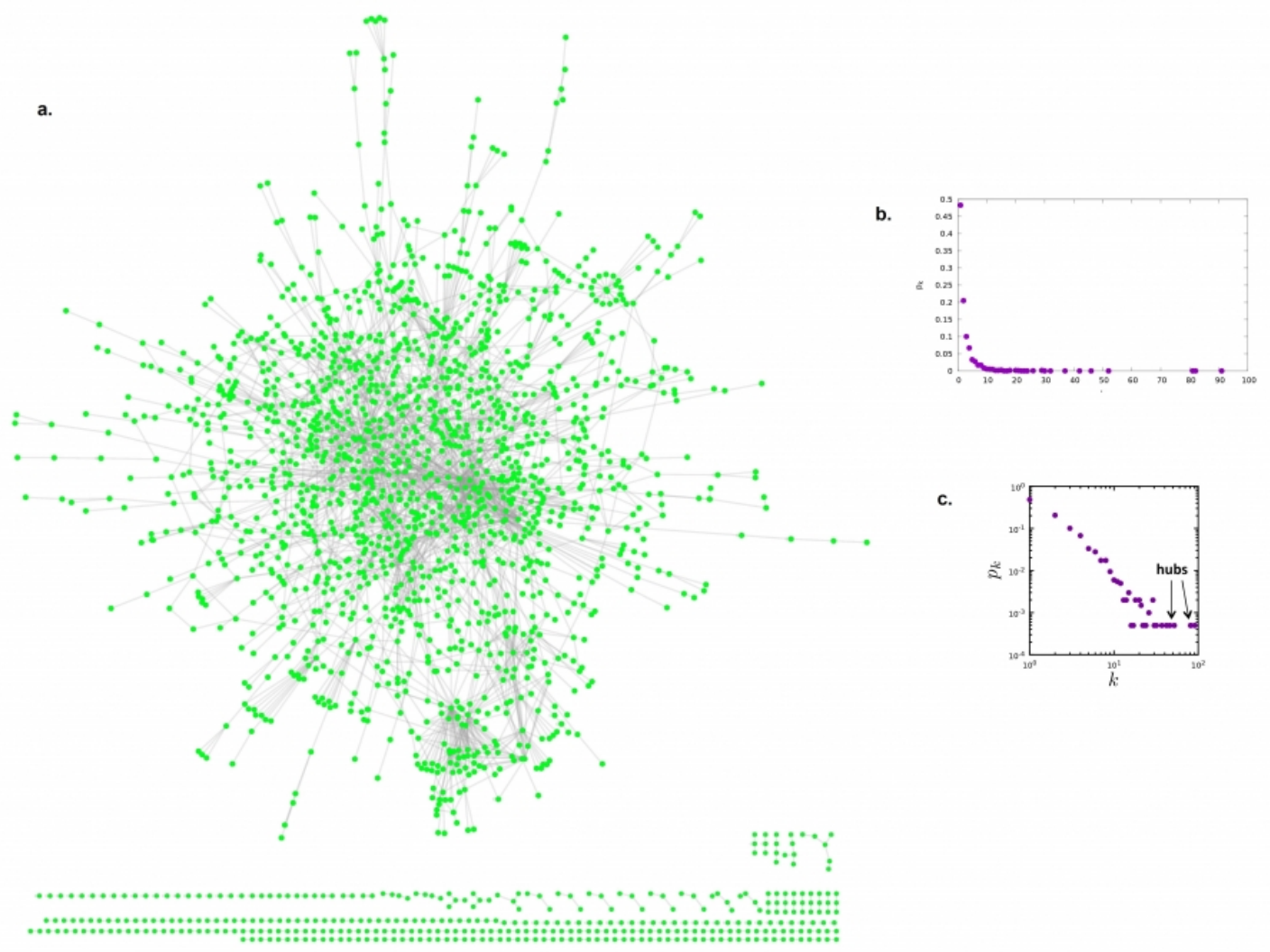

Figura 3. Exemplo de uma rede livre de escala. (a) rede real de interação de proteínas de levedura; (b) Distribuição de graus dessa rede; (c) um gráfico $\log$ - $\log$, no qual é plotado o $\log p_{k}$ em função de $\ln k$, onde $k$ é o grau. Fonte: (BARABÁSI, 2014b) - adaptado. 
As redes livre de escala são bastante comuns e podem ser identificadas nos mais variados contextos tais como: internet, redes biológicas, redes sociais e redes metabólicas. Por exemplo, a Figura 3 apresenta a topologia de uma rede de interação entre proteínas de levedura, a qual segue o modelo livre de escala.

\subsection{Fundamentos Biológicos}

Um gene é a unidade física e funcional básica da hereditariedade. Os genes são subsequências de DNA que funcionam como instruções para gerar as proteínas. A seguir são apresentados alguns fundamentos da estrutura do DNA para um entendimento dos métodos aplicados nesse trabalho.

\subsection{1 Ácidos Nucleicos e Nucleotídeos}

Ácidos nucleicos são polímeros ${ }^{3}$ de nucleotídeos que, por sua vez são moléculas formadas por uma base nitrogenada heterocíclica, uma pentose (açúcar com cinco carbonos) e um fosfato. Segundo o tipo de açúcar formador, tem-se o ácido ribonucleico (RNA) ou ácido desoxirribonucleico (DNA). Os nucleotídeos podem ser hidrolisados em uma pentose e uma base heterocíclica. A pentose é a ribose para os nucleotídeos de RNA ou a desoxirribose para os chamados desoxirribonucleicos, e tem como diferença o carbono 2 do açúcar não hidroxilado (THOMPSON; THOMPSON, 1993). As bases heterocíclicas podem ser derivadas de dois compostos: Purina e Pirimidina, tem-se as bases púricas (adenina e guanina) e as bases pirimídicas (citosina, uracila e timina).

Dos vários tipos de moléculas presentes na célula, os de nosso interesse são as proteínas, por terem diversas funções biológicas. Existem alguns aminoácidos que podem participar da formação das proteínas que são incorporadas no processo de síntese, RNA mensageiro. Na Figura 4 são mostradas as quatro bases do DNA, e as estruturas do DNA e RNA (NUSSBAUM; MCINNES, 2008).

\subsection{2 Ácido Desoxirribonucleico - DNA}

O DNA é um polímero formado por monômeros dos nucleotídeos, ou seja, é uma molécula formado por bases Púricas e Pirimídicas, sendo responsável por toda a informação genética contida nos organismos vivos e pela transmissão às células filhas.

\footnotetext{
${ }^{3}$ Polímero - Tipo de molécula formada quando duas ou mais moléculas chamadas monômeros se combinam umas com as outras.
} 


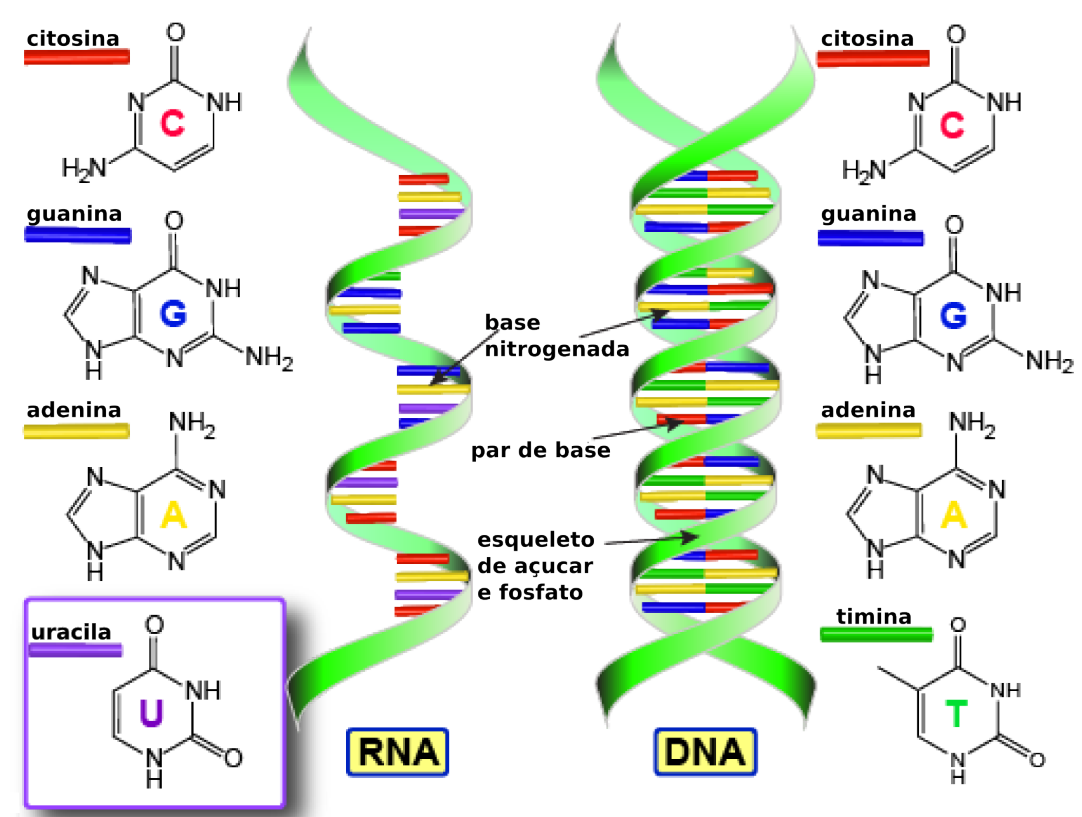

Figura 4. À direita: o modelo de dupla hélice, os degraus horizontais representam o pares de bases do DNA, mostrando os pares de base AT e GC. À esquerda: a estrutura do RNA, sendo que a timina é substituída pela uracila. Fonte: (THOMPSON; THOMPSON, 1993) - adaptado.

Toda informação genética carregada pelo DNA reside na sequência de bases onde há o pareamento de uma fita com outra, formando uma dupla fita (dupla hélice) (Figura 4). Essa interação é estável apenas no sentido antiparalelo (uma fita 5' $\rightarrow$ 3' e a outra no sentido 3' $\rightarrow 5^{\prime}$ ), sendo feito por meio de ligações de hidrogênio entre uma base púrica e uma pirimídica. O pareamento se dá entre uma Adenina (A) e uma Timina (T) (duas pontes de hidrogênio) ou entre uma Guanina $(\mathrm{G})$ e uma Citosina $(\mathrm{C})$ (três pontes de hidrogênio).

A sequência dessas bases codifica instruções. Alguns fragmentos do seu DNA são centros de controle para "ativar"e "desativar"genes, alguns não tem função e outros têm funções que ainda não são entendidas. Outras partes do seu DNA são genes que carregam instruções para sintetizar proteínas que ajudam a construir organismos. A análise da sequência de nucleotídeos do DNA vem constituindo uma importante etapa para a compreensão da vida e da transmissão dos caracteres hereditários e vem sendo de extrema valia na predição e cura de inúmeras doenças existentes (terapia gênica e outros métodos ligados à biologia molecular) (NUSSBAUM; MCINNES, 2008). 


\subsection{3 Ácido Ribonucleico - RNA}

É um polímero formado por monômeros ${ }^{4} \mathrm{e}$ a grande flexibilidade dos RNAs são de executar atividades fundamentais na célula e interpretar o código contido na linguagem de nucleotídios e codificá-la para a linguagem de aminoácidos. Sua síntese ocorre a partir da molécula de DNA que serve de molde e se dá no sentido 5' $\rightarrow$ 3' dessa molécula.

A estrutura química do RNA é semelhante a do DNA, exceto que cada nucleotídeo do RNA possui uma ribose em lugar de uma desoxirribose, tem como diferença o carbono 2 do açúcar não hidroxilado e possui a uracila (U) em vez da timina. Outra diferença é que na maioria dos organismo o RNA existe como uma molécula de filamento único, enquanto o DNA existe como uma dupla hélice (CARVALHO; RECCOPIMENTEL, 2007). Todas as moléculas de proteínas (início da síntese proteica) começam com AUG, o códon de iniciação (metionina), e as moléculas UGA, UAA e UAG (opala, ocre e âmbar), são códons de terminação. A Tabela 1 apresenta o código genético, de forma que cada aminoácido pode ser codificado por um ou mais códons (triplas de bases). Por exemplo, a metionina é determinada pelos códons AUA e AUG (A na $1^{a}$ posição, $U$ na $2^{a}$ posição e $A$ ou $G$ na $3^{\text {a }}$ posição). As caixas azuis representam os códons que iniciam ou terminam a codificação.

Tabela 1. Código genético

\begin{tabular}{|c|c|c|c|c|c|c|c|c|c|c|c|c|c|c|c|c|c|}
\hline \multicolumn{2}{|c|}{ Posição } & \multicolumn{4}{|c|}{ uracila } & \multicolumn{4}{|c|}{ citosina } & \multicolumn{4}{|c|}{ adenina } & \multicolumn{4}{|c|}{ guanina } \\
\hline $1^{a}$ & & \multicolumn{4}{|c|}{$\mathbf{U}$} & \multicolumn{4}{|c|}{ C } & \multicolumn{4}{|c|}{ A } & \multicolumn{4}{|c|}{$\mathbf{G}$} \\
\hline \multirow{4}{*}{$2^{a}$} & $\mathbf{U}$ & feni & Inina & \multicolumn{2}{|c|}{ leucina } & \multicolumn{4}{|c|}{ leucina } & isol & ina & me & ina & \multicolumn{4}{|c|}{ valina } \\
\hline & C & \multicolumn{4}{|c|}{ serina } & \multicolumn{4}{|c|}{ prolina } & \multicolumn{4}{|c|}{ teonida } & \multicolumn{4}{|c|}{ alanina } \\
\hline & A & \multicolumn{2}{|c|}{ tirosina } & ocre & âmbar & \multicolumn{2}{|c|}{ histidina } & \multicolumn{2}{|c|}{ glutamina } & \multicolumn{2}{|c|}{ asparagina } & \multicolumn{2}{|c|}{ lisina } & $\begin{array}{r}\text { á } \\
\text { asp }\end{array}$ & $\begin{array}{l}0 \\
\text { ico }\end{array}$ & \multicolumn{2}{|c|}{$\begin{array}{c}\text { ácido } \\
\text { glutâmico }\end{array}$} \\
\hline & G & \multicolumn{2}{|c|}{ cisteína } & opala & triptofano & \multicolumn{4}{|c|}{ arginina } & \multicolumn{2}{|c|}{ serina } & \multicolumn{2}{|c|}{ arginina } & \multicolumn{4}{|c|}{ glicina } \\
\hline $3^{a}$ & & U & C & A & G & U & C & A & G & U & C & A & G & $\mathbf{U}$ & c & A & G \\
\hline
\end{tabular}

Fonte: (AHUJA, 2014) - adaptado.

\subsubsection{Transferência de Informação Genética}

Nesta seção será descrito (1) como as informações genéticas dos seres vivos são escritas em um alfabeto de apenas quatro letras, as quatro pares de bases do DNA, e (2) como tais informações genéticas são expressas em um organismo e o papel fundamental que o RNA tem nesse processo de expressão gênica. De acordo com o dogma central da biologia molecular, as informações genéticas geralmente fluem (1) de DNA

\footnotetext{
${ }^{4}$ Monômero - Composto por moléculas simples.
} 
para DNA durante sua transmissão de uma geração para outra e (2) do DNA para a proteína durante a expressão fenotípica em um organismo (Figura 5) (SNUSTAD; SIMMONS, 2017). Durante a replicação de RNA, as informações também são transmitidas de RNA para RNA. A transferência de informações genéticas do DNA para as proteínas ocorre em duas etapas: (1) transcrição, a transferência das informações genéticas do DNA para o RNA e (2) tradução, a transferência de informações do RNA para as proteínas. Além disso, as informações genéticas fluem do RNA para o DNA durante a conversão dos genomas de RNA em suas formas de DNA. Portanto, às vezes, a transferência de informações genéticas do DNA para o RNA é reversível, enquanto a transferência de informações do RNA para as proteínas é sempre irreversível.

\section{0 dogma central}

Fluxo de informações genéticas:

1. Perpetuação das informações genéticas de uma geração para outra

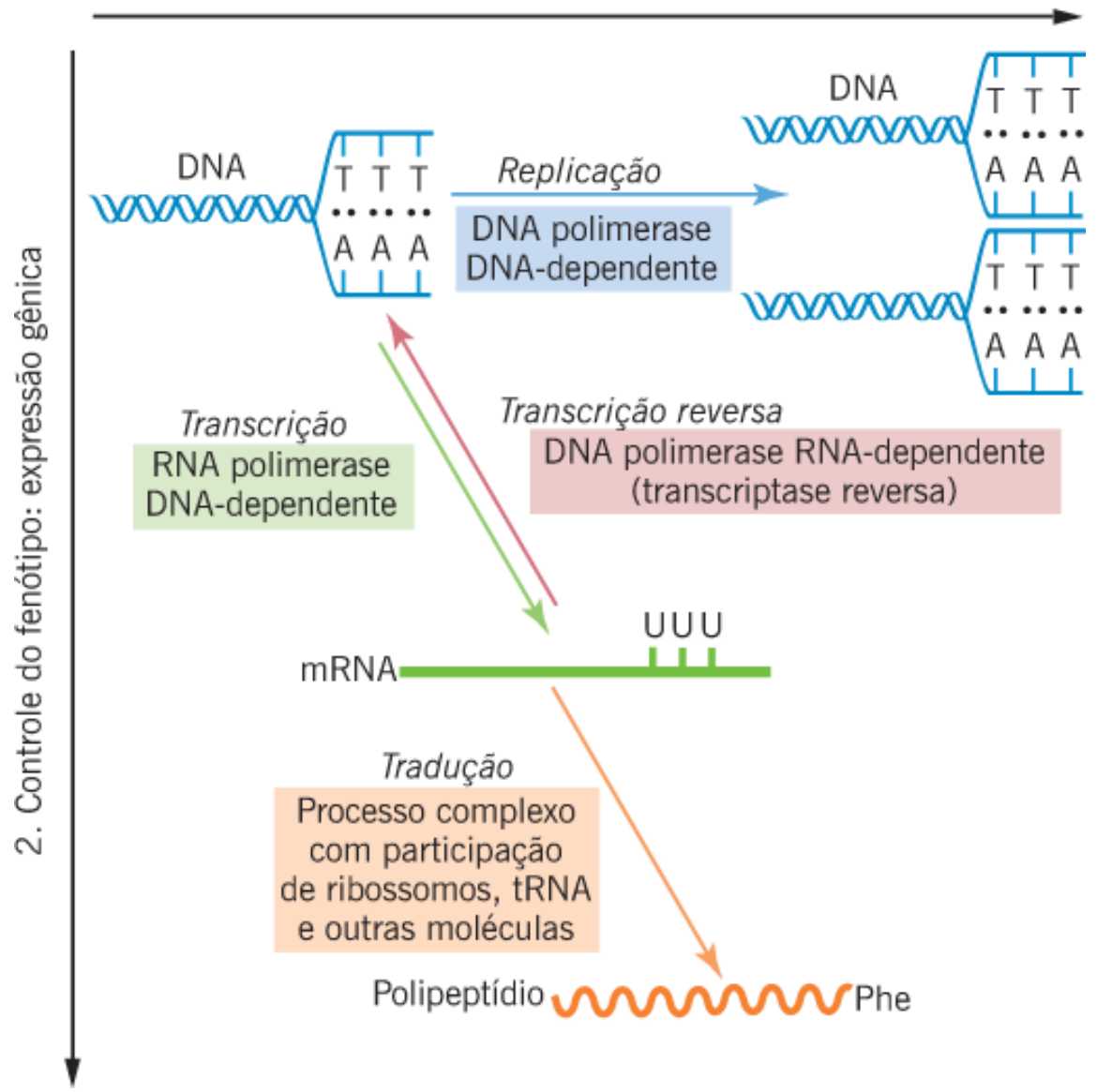

Figura 5. O fluxo de informações genéticas de acordo com o dogma central da biologia molecular. Replicação, transcrição e tradução ocorrem em todos os organismos; a transcrição reversa ocorre em células infectadas por determinados vírus de RNA. A transferência de informações de RNA para RNA durante a replicação dos vírus de RNA não é mostrada.

Fonte: (SNUSTAD; SIMMONS, 2017) - adaptado. 


\section{Processo de expressão gênica: transcrição e tradução}

A transcrição e a tradução são as duas etapas cruciais da expressão da informação genética. De acordo como (HEALTH, 2014), é através dos processos de transcrição e tradução, que a informação dos genes é usada para produzir proteínas, (Figura 6).

Durante a transcrição, um filamento de DNA de um gene é usado como modelo para sintetizar um filamento complementar de RNA, denominado transcrito gênico. Por exemplo, na Figura 5, o filamento de DNA que contém a sequência AAA de nucleotídeos é usada como modelo para produzir a sequência complementar UUU no transcrito de RNA.

Durante a tradução, a sequência de nucleotídeos no transcrito de RNA é convertida na sequência de aminoácidos no produto gênico polipeptídico. Essa conversão é traduzida conforme a tabela do código genético (Tabela 1) (SNUSTAD; SIMMONS, 2017).

A tradução ocorre em aparelhos macromoleculares complexos chamados ribossomos, constituídos de três a cinco moléculas de RNA e de 50 à 90 proteínas diferentes. Além disso, o processo de tradução também requer a participação de muitas outras macromoléculas. As moléculas de RNA traduzidas nos ribossomos são denominadas RNA mensageiros (mRNA). Em procariotos, o produto da transcrição, o transcrito primário, geralmente equivale à molécula de mRNA (Figura 6a). Em eucariotos, muitas vezes é preciso processar os transcritos primários por excisão de sequências específicas e modificação de ambas as terminações antes que possam ser traduzidos (Figura 6b) (SNUSTAD; SIMMONS, 2017).

O fenótipo de um organismo é produzido pelos efeitos combinados da ação de todos os seus genes dentro dos limites impostos pelo ambiente. As relações entre as informações de DNA e RNA são circulares: o DNA dirige a síntese e a sequencia de RNA; o RNA dirige a síntese e sequencia de polipeptídeos ${ }^{5}$; e as proteínas específicas estão envolvidas na síntese e metabolismo de DNA e RNA (NUSSBAUM; MCINNES, 2008).

\footnotetext{
${ }^{5}$ Polipeptídeo ou peptídeo corresponde a um polímero linear de mais de vinte aminoácidos estabelecendo entre si ligações peptídicas.
} 


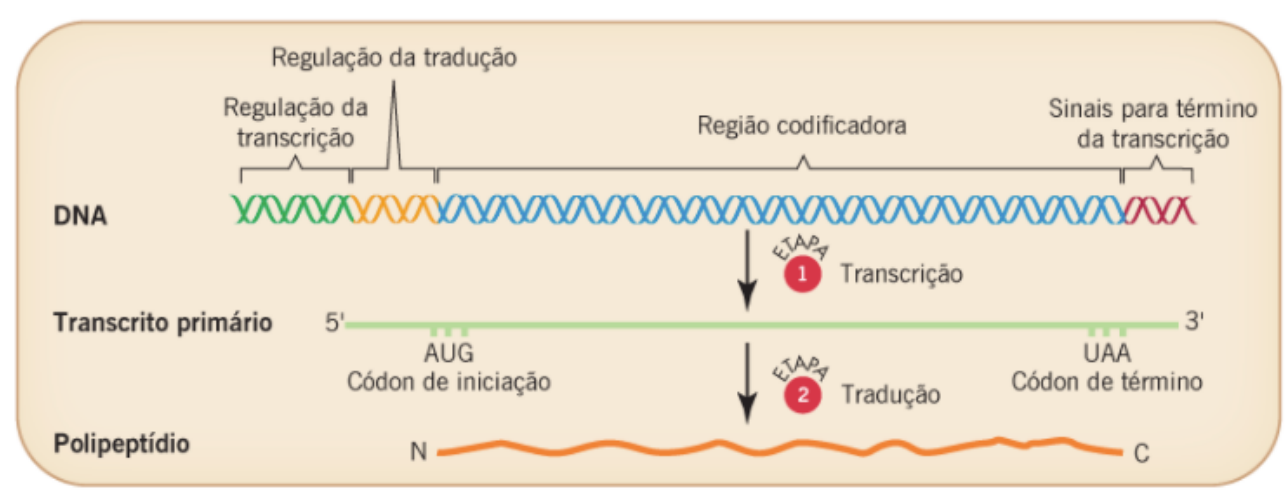

(a)

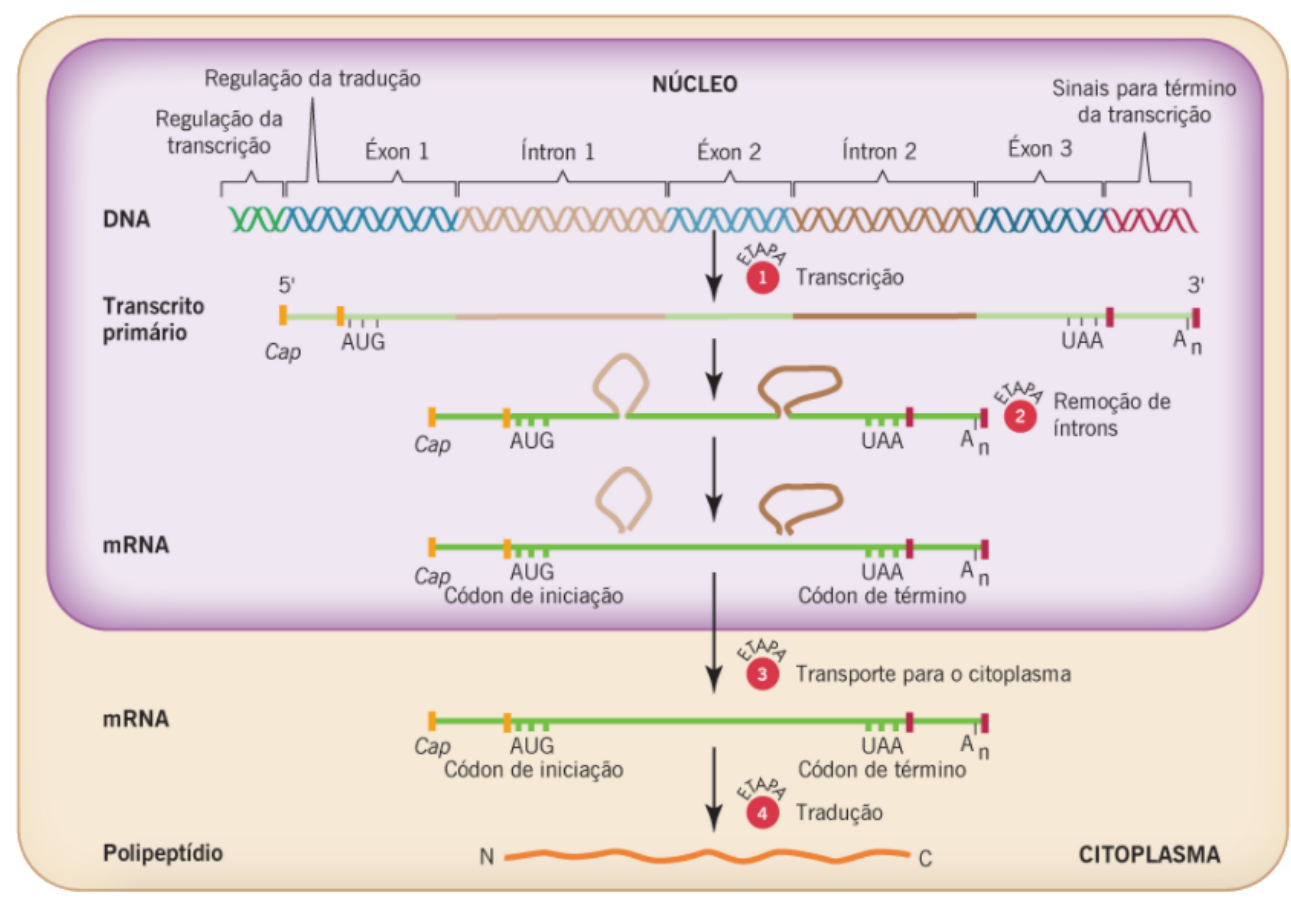

(b)

Figura 6. A expressão gênica ocorre em duas etapas: transcrição e tradução, tanto em procariotos (a) quanto em eucariotos (b). Em eucariotos, muitas vezes os transcritos primários ou pré-mRNA têm de ser processados por excisão de íntrons e acréscimo de caps 5' de 7metilguanosina e de cauda poli(A) 3' $\left[(A)_{n}\right]$. Além disso, os mRNA eucarióticos têm de ser transportados do núcleo para o citoplasma, onde são traduzidos. Fonte: (SNUSTAD; SIMMONS, 2017) - adaptado.

\subsubsection{Dados de Expressão Gênica}

Existem diversos métodos para medir níveis de RNA em larga escala. Entre eles podemos destacar os métodos de DNA Microarrays ${ }^{6}$ e RNA-seq ${ }^{7}$ que são capazes

\footnotetext{
${ }^{6}$ Também conhecido como DNA chip, DNA Microarrays são utilizados para analisar de forma simultânea a expressão gênica de um grande número de genes.

${ }^{7}$ Também conhecido como Whole Transcriptome Shotgun Sequencing. RNA-seq (RNA sequencing) possui como vantagem perante DNA Microarrays o fato de ter uma cobertura mais abrangente sobre o
} 
de monitorar e extrair informação de milhares de genes simultaneamente. Genes são fragmentos de DNA responsáveis por codificar funções celulares, entre os quais os mais estudados são as proteínas (VIGNES et al., 2011). A regulação gênica é formada por uma sequência de processos, como por exemplo a transcrição e a tradução, que controlam os níveis de expressão dos genes e tem na maioria das vezes uma proteína como produto (BRAZHNIK; FUENTE; MENDES, 2002).

Para inferir a função dos genes ou medir o quanto são expressos, as tecnologias monitoram a quantidade de RNAs mensageiros produzidos durante a fase de transcrição (transcritos). Essas medidas podem informar sobre a expressão diferencial dos genes entre diferentes experimentos ou através do tempo. Esse tipo de análise pode ser realizada para identificar genes em condições de interesse, como por exemplo testes de células doentes e submetidas a um tratamento. Também pode-se obter amostras ao longo do tempo para se realizar uma análise da evolução temporal de uma cultura de células. Enquanto a sequência de DNA nos diz o que a célula pode fazer, o perfil de expressão gênica é uma amostra do estado dos genes em determinadas condições.

Os dados de expressão gênica são normalmente dispostos em uma matriz $N \times$ $M$ na qual os $N$ genes são dispostos nas linhas e as $M$ amostras experimentais são dispostas nas colunas. A célula $(i, j)$ dessa matriz representa o valor da expressão do gene $i$ na amostra $j$ (Figura 7a). Embora os valores de expressão sejam contínuos, algumas análises requerem que eles sejam discretizados (quantizados) de algum modo (Figura 7b).

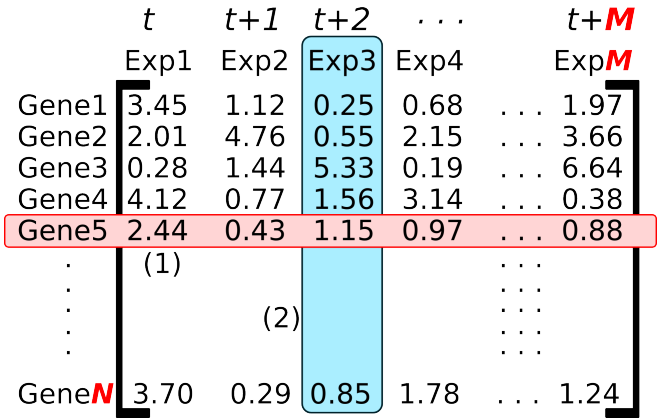

(a)

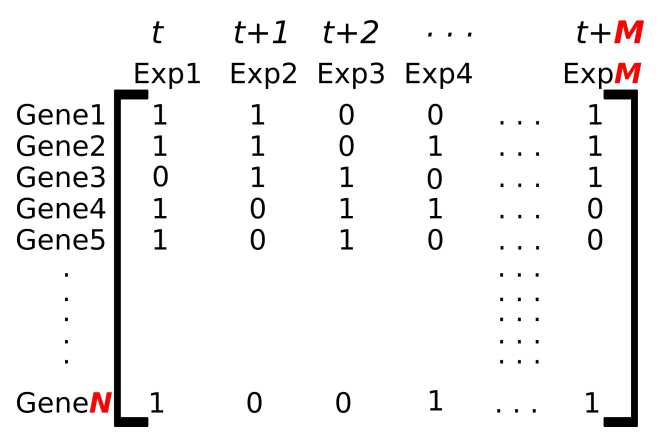

(b)

Figura 7. Exemplos de matrizes de DNA Microarrays discretizadas $(N \times M)$ : (a) a linha representa os dados (ou perfil) de expressão do gene 5 em todos os experimentos (ou instantes de tempo); e a coluna em destaque na cor azul, a expressão no tempo $(t+2)$ de todos os genes; (b) Dados discretizados (quantizados).

genoma e tem sido amplamente adotado pela comunidade científica nos últimos anos (CHU; COREY, 2012). 


\subsection{Redes de Regulação Gênica}

\subsubsection{Considerações preliminares sobre modelagem e inferência}

Genes e proteínas agem em conjunto, formando uma intrincada rede regulatória denominada rede gênica, onde um conjunto de genes pode interagir entre si, e o produto dessa interação pode influenciar outros genes. A análise da expressão dos genes pode fornecer pistas sobre os mecanismos de regulação e interação entre os genes. $O$ processo de inferência de redes de regulação gênica pode ser baseados em dados de expressão contínuos, conforme exemplificado na Figura 7a, ou discretizados (quantizados), conforme exemplificado na Figura 7b. Esses dados são considerados características que representam estados de experimentos ou de instantes de tempo distintos.

Redes de regulação gênica (GRN) são modelos capazes de representar as relações de regulação entre os genes, representando como a mudança de atividade em um ou mais genes pode afetar a atividade de outros (BRAZHNIK; FUENTE; MENDES, 2002). A maioria dos modelos de GRNs representam uma rede gênica por meio de um grafo no qual os vértices representam os genes, proteínas e/ou metabolitos ${ }^{8}$ e as arestas as possíveis interações moleculares, tais como a proteína-DNA ou proteína-proteína. A atividade funcional e os produtos dos genes são influenciadas não só por fatores de transcrição (FT) e cofatores que podem influenciar a transcrição, mas também pela degradação das proteínas e dos transcritos, bem como a modificação pós-tradução das proteínas, conforme ilustrado na Figura 8 (HECKER et al., 2009).

A inferência (reconstrução) de redes gênicas a partir de dados experimentais também é chamado de engenharia reversa. A engenharia reversa de GRNs é uma tarefa desafiadora tanto do ponto de vista computacional como do ponto de vista estatístico, já que o problema em si é de natureza fortemente combinatória (encontrar a combinação certa de reguladores em um conjunto de dados de alta dimensão, da ordem dos milhares) e as amostras disponíveis são normalmente limitadas e imprecisas.

O fluxograma típico de um processo de inferência de um sistema regulatório pode ser visto na Figura 9. Esse processo é baseado em experimentos (amostras) de expressão gênica de um determinado organismo de interesse. Esses dados são submetidos a comparações com predições geradas por modelos matemáticos construídos a partir de algum conhecimento biológico sobre o mecanismo regulatório. Esses modelos vêm sendo evoluídos constantemente, para corrigirem e serem aperfeiçoados para uma melhor predição da realidade representada pelos dados experimentais. A Figura 9 ilustra um fluxograma desse processo (DE-JONG, 2002).

\footnotetext{
${ }^{8}$ Produto do metabolismo de uma determinada molécula ou substância.
} 

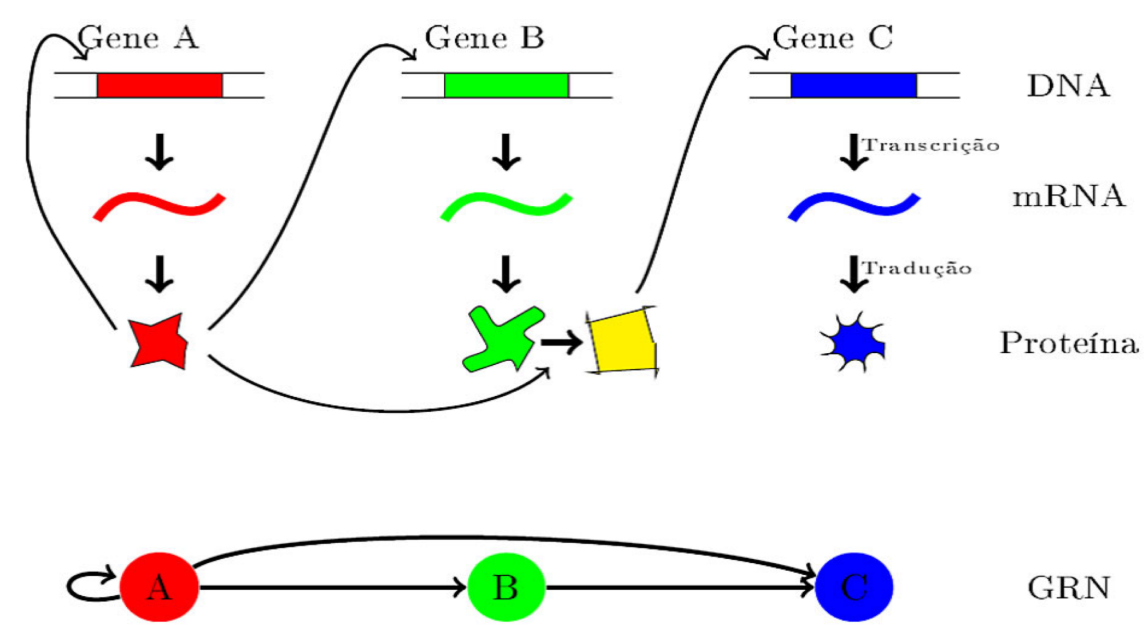

Figura 8. Visão esquemática de uma rede gênica simples. O gene A regula a sua própria expressão e a expressão do gene B. Deste modo, o gene pode exercer a sua influência reguladora direta (se ele codifica um FT) ou indiretamente (se ele controla a atividade de um outro FT, possivelmente através de uma cascata de sinalização). Ao reconstruir a GRN, muitas vezes tem-se como objetivo inferir um modelo de rede. Fonte: (HECKER et al., 2009) - adaptado.

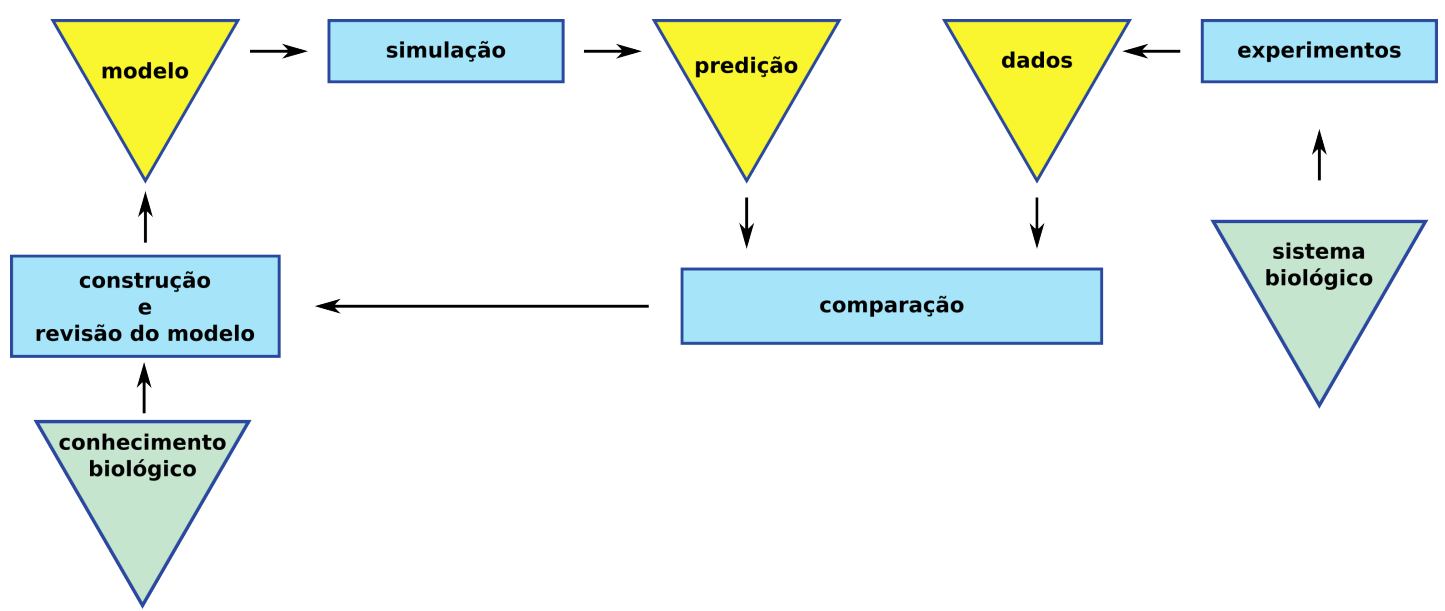

Figura 9. Processo de análise de redes de regulação gênica. Os retângulos representam procedimentos que realizam um certo processamento, os triângulos representam fontes de informação e as setas indicam o fluxo da informação. Fonte: (DE-JONG, 2002) - adaptado.

Existem duas abordagens principais para modelar redes gênicas (SHMULEVICH; DOUGHERTY, 2014): contínuas e discretas. As abordagens contínuas consideram principalmente equações diferenciais para obter um modelo detalhado quantitativo de redes bioquímicas enquanto modelos discretos medem as interações gênicas do ponto de vista qualitativo. Os principais modelos discretos incluem os que se baseiam em grafos como redes Bayesianas (RB) (FRIEDMAN et al., 2000), redes Booleanas (KAUFFMAN, 1969), e suas versões estocásticas redes Booleanas probabilísticas (PBN) (SHMULEVICH et al., 2002) e redes gênicas probabilísticas (PGN), um modelo simplificado de PBN (BARRERA et al., 2007). Os modelos contínuos fornecem uma compreensão detalhada do sistema, mas exigem informação prévia sobre parâme- 
tros cinéticos e um volume maior de amostras experimentais (HECKER et al., 2009). Por outro lado, os modelos discretos são mais úteis para capturar o comportamento global da dinâmica do sistema, exigindo menos dados e sendo mais fácil de implementar e analisar (IVANOV; DOUGHERTY, 2006; HECKER et al., 2009), entre outros.

No contexto específico de modelos discretos, BNs e PBNs podem generalizar e capturar o comportamento global de sistemas biológicos (KAUFFMAN, 1969; SHMULEVICH et al., 2002). A principal desvantagem destes modelos é a perda de informação como consequência da quantização dos dados que se fazem necessários. No entanto, a quantização torna os modelos BN e PBN mais simples de implementar e analisar (STYCZYNSKI; STEPHANOPOULOS, 2005; IVANOV; DOUGHERTY, 2006), e muitos métodos foram propostos para inferir GRNs modeladas como BN ou PBN (AKUTSU et al., 1999; LAHDESMAKI; SHMULEVICH, 2003; LIANG; FUHRMANE; SOMOGYI, 1998; NAM; SEO; KIM, 2006).

Embora os genes nas BNs e PBNs tenham apenas dois possíveis valores de expressão, a inferência dessas redes ainda é considerada um problema em aberto, tendo em vista que a maldição da dimensionalidade ainda desempenha um papel importante. Desta forma, a PGN fornece uma simplificação do processo de inferência de PBNs que permite a aplicação de seleção de características local para cada gene alvo de modo a procurar pelos melhores subconjuntos de genes que predizem o comportamento de um determinado gene alvo (BARRERA et al., 2007; LOPES; MARTINS-JR; CESAR-JR, 2008a).

Uma vez que a busca exaustiva é o único algoritmo de seleção de características que garante otimalidade (COVER; VAN-CAMPENHOUT, 1977), técnicas de computação de alto desempenho são necessárias quando se utiliza este algoritmo para procurar por subconjuntos preditores de dimensão três ou quatro (para dimensões superiores, esta técnica ainda é impraticável) (BORELLI et al., 2013; CARASTAN-SANTOS et al., 2017). Sendo assim, o foco desta pesquisa será dado em inferência de redes gênicas modeladas por PGNs.

A literatura que lida com o problema de inferência GRNs é vasta. Alguns exemplos de métodos que lidam com este problema incluem as baseadas em seleção de características por informação mútua (LIANG; FUHRMANE; SOMOGYI, 1998; BARRERA et al., 2007; LOPES; MARTINS-JR; CESAR-JR, 2008b; LOPES et al., 2014), redes de relevância (MARGOLIN et al., 2006; FAITH et al., 2007), seleção de características por relevância máxima / redundância mínima (MEYER et al., 2007), perturbação de sinal (IDEKER; THORSSON; KARP, 2000; CARASTAN-SANTOS et al., 2017), entre outros. 
Embora haja muitos métodos de inferência de GRNs na literatura (MARKOWETZ; SPANG, 2007; HECKER et al., 2009; DE-SMET; MARCHAL, 2010; MARBACH et al., 2012; RISTEVSKI, 2013), a inferência de GRNs é considerada um problema mal posto, uma vez que, para um determinado conjunto de dados de perfis de expressão gênica, existem muitas redes (senão infinitas) capazes de explicar este mesmo conjunto de dados. Este problema é ainda mais dificultado devido a um número tipicamente limitado de amostras, uma enorme dimensionalidade (número de variáveis, ex., genes), além da presença de ruído, conforme já mencionado anteriormente (HECKER et al., 2009; SHMULEVICH; DOUGHERTY, 2014).

\subsubsection{Redes Booleanas}

A representação das redes de regulação gênica por meio de grafos facilita a visualização das interações (arestas) entre os genes (vértices), mas por si só não permite especificar um mecanismo da dinâmica ou o tipo de relação entre os genes. Uma forma simples desta representação é atribuir valores binários para os estados dos genes: 0 para os genes inativos e 1 para genes ativos. Desta forma, a dinâmica dos genes ao longo do tempo é determinada pela topologia da rede (ligações entre os genes) e pela aplicação de funções Booleanas (regras lógicas).

De acordo com D’haeseleer, Liang and Somogyi (2000) uma rede Booleana é definida por um conjunto de genes $\mathrm{G}=\left\{g_{1}, g_{2}, \ldots g_{n}\right\} \in\{0,1\}^{n}$, e um conjunto de funções de transição Booleanas $\Psi=\left\{\psi_{1}, \psi_{2}, \ldots, \psi_{n}\right\}, \psi_{i}:\{0,1\}^{n} \rightarrow\{0,1\}, \forall i \in\{1,2, \ldots, n\}$, uma função de transição para cada gene. Cada gene $g_{i}$ em uma BN representa um estado de ativação do gene na forma binária, e seu valor no instante $t+1$ é determinado pelos valores dos seus $k$ genes preditores $\left\{g_{i}^{1}, g_{i}^{2}, \ldots g_{i}^{k}\right\}$ no instante de tempo $t$ através da aplicação de sua $\psi$ que toma como entrada os valores dos seus genes preditores $\left\{g_{i}^{1}, g_{i}^{2}, \ldots g_{i}^{k}\right\}$ no instante $t$ e devolve o valor o gene $g_{i}$ (alvo) no instante $t+1$.

Desta forma, as funções de transição Booleanas ( $\Psi$ ) são usadas para atualização dos valores dos genes, considerando iterações discretas e síncronas ao longo do tempo. Isso simplifica o processamento e a estimação estatística, mantendo a estrutura da dinâmica da rede (LOPES, 2011). A Figura 10a apresenta uma rede Booleana, sendo possível observar que $g_{2}$ ativa $g_{1}$, e $g_{1}$ inibe $g_{2}$. O gene $g_{3}$ é ativado se o gene $g_{1}$ ou ( OR ) o gene $g_{2}$ estiver ativo. Na Figura 10 b, é apresentada uma tabela de transição de estados possíveis da rede com 3 genes. Cada estado é representado por uma sequência de bits. Na Figura 10c é ilustrado um diagrama de transição de estados da rede Booleana considerada. 


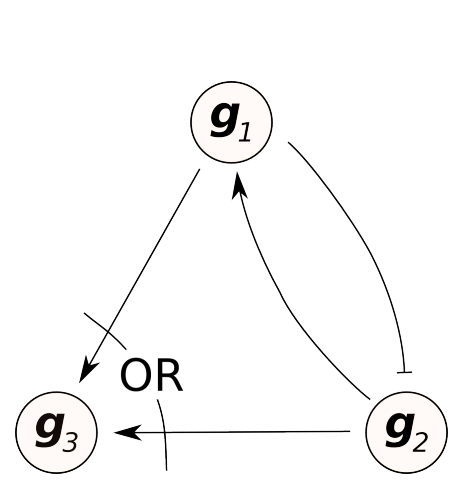

(a)

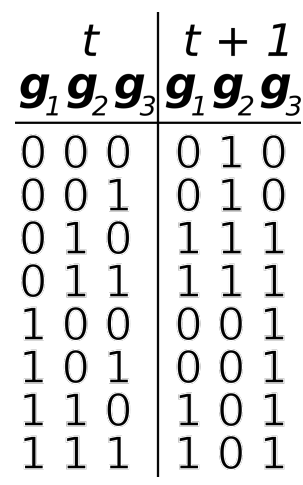

(b)

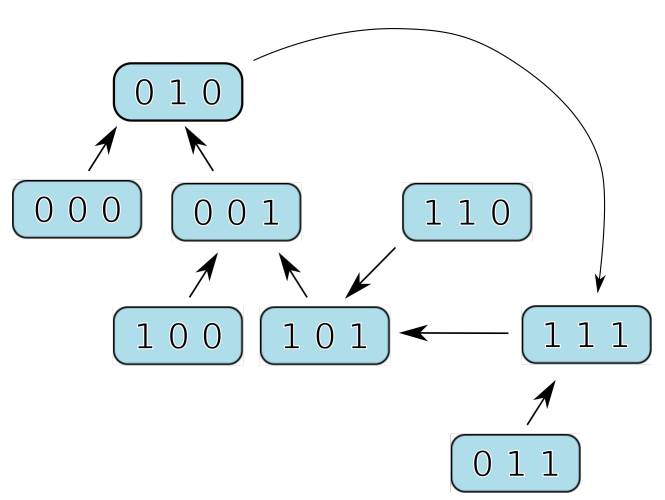

(c)

Figura 10. (a) Uma rede de três elementos binários (dígrafo); (b) Tabela de transição de estados possíveis da rede de 3 elementos do lado esquerdo, da matriz de $8 \times 3$ e abaixo do instante $(t)$; O estado subsequente no momento $(t+1)$, está à direita da tabela; (c) Um grafo mostrando a sequência de transições de estado que levam a um estado de comprimento 3. Fonte: (KAUFFMAN, 1969) - adaptado.

Uma vantagem em adotar o modelo booleano está justamente na sua forma simples de representar os dados (binário), e o número finito $\left(2^{n}\right)$ de estados que o sistema pode assumir. Modelar um sistema biológico adotando um modelo booleano determinístico, traz algumas vantagens e algumas propriedades de interesse que pode explicar o comportamento e as relações entre os diversos elementos desse sistema, dado que as redes biológicas são quasi-determinísticas (KAUFFMAN, 1991; KAUFFMAN, 1993; GREEN, 1993; BOSSOMAIER; GREEN, 2000), isso motiva o uso do modelo de Redes Booleanas Probabilísticas, conforme descrito a seguir.

\subsubsection{Redes Booleanas Probabilísticas}

O modelo de redes Booleanas probabilísticas (PBN) foi introduzido por Shmulevich et al. (2002). Essas redes compartilham propriedades interessantes das redes Booleanas, com a diferença de serem capazes de lidar com a incerteza, tanto em relação aos dados como em relação a seleção de modelos.

Existem várias razões para utilizar PBNs. Esse modelo assume a existência de estocasticidade no comportamento do sistema e são capazes de modelar a dinâmica de uma rede gênica de acordo com um conjunto de funções de transição de probabilidades.

Um modelo Booleano incorpora apenas descrições parciais de um sistema real. Em muitas situações, não se sabe exatamente qual será o valor de expressão de um gene no próximo instante de tempo. Neste sentido, a expressão de um gene pode depender de mais de uma função de transição, sendo que a função a ser aplicada em 
um dado momento pode depender de um contexto (DOUGHERTY et al., 2009). Uma PBN envolve um conjunto de funções booleanas para cada variável, sendo que a cada instante de tempo, uma dessas funções é escolhida com uma certa probabilidade para melhor descrever o funcionamento de um determinado gene de interesse, ao contrário do caso determinístico, que cada gene fica restrito a uma única função.

As PBNs são uma família particular de cadeias de Markov dada pela função de transição estocástica para descrever o funcionamento de uma GRN (BERLOW; PAL, 2011). Desta forma, ela pode ser generalizada por $\vec{x}_{i}(k+1)=f_{i}(\vec{x})(k)$, em que $f_{i}$ é uma função em $f_{i}:\{0,1\}^{n} \rightarrow\{0,1\}$.

A estocasticidade é introduzida no modelo atribuindo para cada gene $i$ um conjunto de $l(i)$ tuplas, cada qual composta por uma função $f_{i}^{(i)}:\{0,1\}^{n} \rightarrow\{0,1\} \mid j \in$ $\{1, \cdots, l(i)\}$ e sua probabilidade associada $c_{i}^{(i)}$, em que $\sum_{i=1}^{l(i)} c_{i}^{(i)}=1$.

A cada mudança de estado é realizado um sorteio de uma função $f_{i}{ }^{(i)}$ para definir se o gene $i$ está expresso ou não no instante de tempo seguinte $(t+1)$. Desta forma se torna claro que se $l(i)=1$ para todo $i=1, \cdots, n$, a PBN se reduz a uma rede Booleana determinística. Assim, uma PBN é equivalente a sortear uma dentre $v$ possíveis vetores de funções Booleanas $\Psi=\left\{\psi_{1}, \psi_{2}, \ldots, \psi_{n}\right\}, \psi_{i}:\{0,1\}^{n} \rightarrow\{0,1\}, \forall i \in\{1,2, \ldots, n\}$, sendo $v$ definida por:

$$
v=\prod_{i=1}^{n} l(i)
$$

sendo que cada rede Booleana $(\mathrm{BN})$ tem a seguinte probabilidade de ser selecionada:

$$
P(B N)=\prod_{i=1}^{n} c_{i}^{(i)} \mid f_{B N}^{(i)}=f_{j}{ }^{(i)}
$$

A Tabela 2 ilustra um exemplo de uma PBN com dois genes preditores $x_{1}$ e $x_{2}$ prevendo um gene alvo $x_{4}$. Por exemplo, a probabilidade do gene $x_{4}$ estar ativo (1), dado que $x_{1}$ está inativo (0) e $x_{2}$ está ativo (1) é $P\left(x_{4}=1 \mid x_{1}=0, x_{2}=1\right)=0,90$.

Tabela 2. Exemplo de tabela contendo as probabilidades condicionais de um gene de uma PBN.

\begin{tabular}{|c|c|c|c|}
\hline $\boldsymbol{x}_{\mathbf{1}}$ & $\boldsymbol{x}_{\mathbf{2}}$ & $\boldsymbol{P}\left(\boldsymbol{x}_{\mathbf{4}}=\mathbf{0} \mid \boldsymbol{x}_{\mathbf{1}}, \boldsymbol{x}_{\mathbf{2}}\right)$ & $\boldsymbol{P}\left(\boldsymbol{x}_{\mathbf{4}}=\mathbf{1} \mid \boldsymbol{x}_{\mathbf{1}}, \boldsymbol{x}_{\mathbf{2}}\right)$ \\
\hline 0 & 0 & 0,97 & 0,03 \\
\hline 0 & 1 & 0,10 & 0,90 \\
\hline 1 & 0 & 0,20 & 0,80 \\
\hline 1 & 1 & 0,30 & 0,70 \\
\hline
\end{tabular}




\subsubsection{Redes Gênicas Probabilísticas}

O modelo de Redes Gênicas Probabilísticas (Probabilistic Gene Networks - PGN) é um tipo restrito de PBN que assume algumas hipóteses simplificadoras para lidar com os problemas inerentes à inferência de redes gênicas conforme discutido anteriormente (BARRERA et al., 2007).

Assim como as PBNs, as PGNs assumem que as amostras de expressão gênica temporais seguem uma Cadeia de Markov de primeira ordem. As 4 hipóteses (ou axiomas) das PGNs são inspiradas em fenômenos biológicos ou simplificações obrigatórias devido à usual falta de amostras para uma estimação adequada dos parâmetros do modelo. O axioma ( $i$ ) é uma restrição para simplificar o problema e o comportamento de cada gene alvo em um determinado instante de tempo, dependendo somente do comportamento do seu subconjunto de genes preditores no instante de tempo anterior. O axioma (ii) impõe que todos os estados são alcançáveis e a função de transição do modelo PGN é homogênea (não muda ao longo do tempo), quase determinística (de qualquer estado, o sistema tem um estado preferencial para visitar). O axioma (iii) diz que a matriz de transição de probabilidades condicionais entre os estados é condicionalmente independente (isto é, o valor de expressão de um dado gene é dependente apenas de seus preditores, seguindo a hipótese de Markov). Além disso, diferentemente das PBNs, as PGNs possuem a flexibilidade de assumir que os genes tenham dois ou mais valores discretos possíveis. O número de níveis de quantização pode ser determinado de acordo com a quantidade de amostras disponíveis para uma boa estimativa dos parâmetros do modelo, e o axioma (iv) diz que o sistema tem uma dinâmica estrutural que esta sujeita a pequenos ruídos (BARRERA et al., 2007).

\subsubsection{Inferência de Redes Gênicas Probabilísticas}

A independência condicional assumida pelo modelo PGN é uma hipótese simplificadora importante que permite que um processo de seleção de características seja aplicado para cada gene alvo de maneira independente, na busca pelo melhor subconjunto preditor. Nesse sentido, um fluxo típico de inferência de uma PGN pode ser visto na Figura 11.

(a) Dados de entrada: os dados de entrada para a inferência de PGNs consistem em um conjunto de dados de perfis de expressão gênica cujas amostras representam uma série temporal. Esses dados são estruturados em uma matriz $N \times M$, com $N$ genes e $M$ instantes de tempo consecutivos. Um exemplo da estrutura desses dados pode ser 


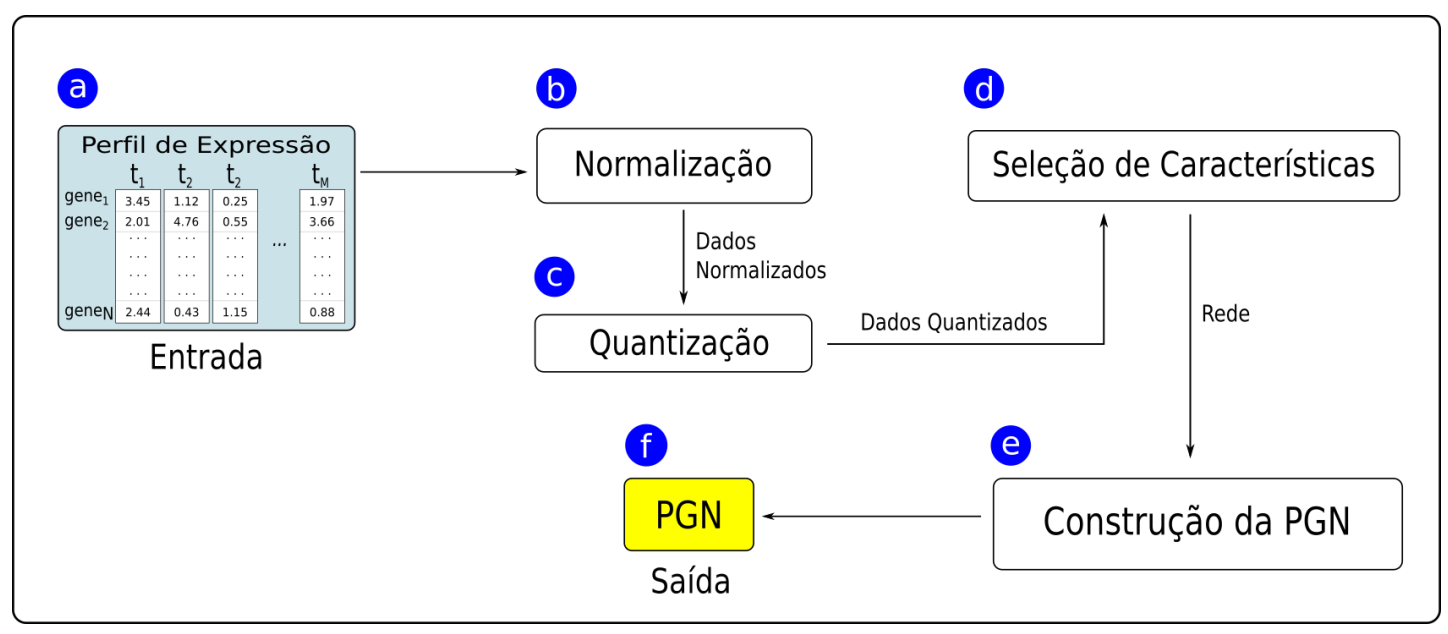

Figura 11. As principais etapas tipicamente executadas para inferir redes gênicas seguindo o modelo de Redes Gênicas Probabilísticas (PGN). A caixa em azul clara (a) representa a entrada (dados de expressão gênica), e a caixa amarela (f) representa a rede PGN inferida.

observado na Figura 12a. Usualmente os valores de expressão são reais (contínuos).

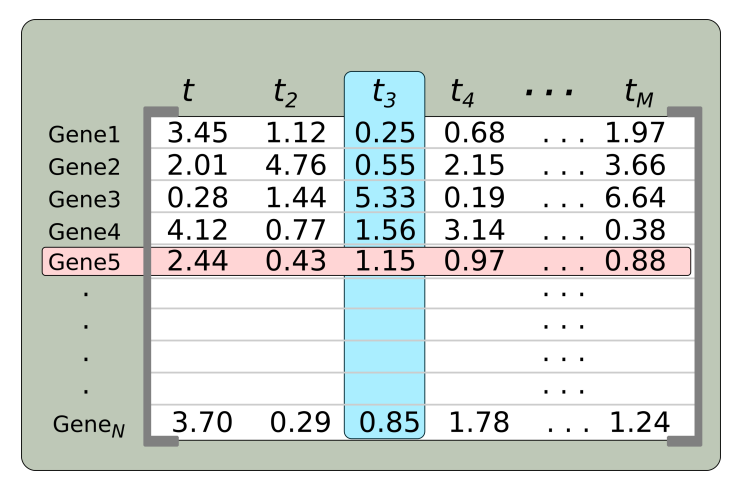

(a)

\begin{tabular}{|c|c|c|c|c|c|c|}
\hline & $t$ & $t_{2}$ & $t_{3}$ & $t_{4}$ & $\cdots$ & $t_{M}$ \\
\hline Gene1 & 1 & 1 & 0 & 0 & $\ldots$ & 1 \\
\hline Gene2 & 1 & 1 & 0 & 1 & $\ldots$ & 1 \\
\hline Gene3 & 0 & 1 & 1 & 0 & $\ldots$ & 1 \\
\hline Gene4 & 1 & 0 & 1 & 1 & $\ldots$ & 0 \\
\hline Gene5 & 1 & 0 & 1 & 0 & $\ldots$ & 0 \\
\hline · & & & & & $\ldots$ & \\
\hline . & & & & & $\cdots$ & \\
\hline . & & & & & $\ldots$ & \\
\hline . & & & & & $\ldots$ & \\
\hline Gene $_{N}$ & 1 & 0 & 0 & 1 & $\ldots$ & 1 \\
\hline
\end{tabular}

(b)

Figura 12. Exemplo de um conjunto de dados de expressão gênica: (a) matriz original: para cada linha os valores de expressão do gene e cada coluna uma amostra temporal; (b) dados de expressão quantizados em dois níveis (binário). 
(b) Normalização: os dados de expressão geralmente são oriundos de diferentes experimentos realizados, onde cada instante de tempo (amostra) pode estar sujeita a variações e ruídos intrínsecos. Então uma operação de normalização se faz necessária para que os dados sejam comparáveis, (Figura 11b).

Um procedimento usual de normalização dos dados de expressão é a transformação normal ou Z-score que transforma os dados de tal forma que cada valor de expressão gênica possua média zero (0) e desvio padrão um (1) (AZUAJE; DOPAZO, 2005; BARRERA et al., 2007; LOPES; MARTINS-JR; CESAR-JR, 2008a). Assim, o valor de expressão $v e_{i}$ de um dado gene $i$ torna-se:

$$
v e_{i}^{\prime}=\frac{v e_{i}-\mu_{i}}{\sigma_{i}}
$$

em que $\mu_{i}$ e $\sigma_{i}$ são respectivamente: média e desvio padrão dos dados de expressão do gene $i$.

Essa transformação tem como objetivo ajustar os dados de tal forma que os valores de expressão de um dado gene abaixo de sua própria média tornam-se negativos (subexpressos), enquanto valores de expressão acima de sua própria média tornam-se positivos (superexpressos) (CHEADLE et al., 2003; BARRERA et al., 2007; LOPES; MARTINS-JR; CESAR-JR, 2008a). Esta característica é importante para preservar a forma do sinal (perfil) de expressão do gene.

Quantização: Devido ao fato do modelo PGN ser discreto, o conjunto de dados de expressão gênica deve ser quantizado de tal maneira que apresentem um conjunto finito de valores possíveis (Figura 11c). Normalmente aplica-se a quantização aos dados previamente normalizados. Por exemplo, ao utilizar a transformação Z-Score conforme definida na Equação 2.5, para transformar os valores contínuos em valores binários (binarização) basta fazer com que os valores negativos (subexpressos ou expressos abaixo da média) se tornem zero (0) e os valores positivos se tornem um (1). A Figura $12 \mathrm{~b}$ exemplifica a binarização dos dados normalizados. Entretanto, é possível quantizar em mais de dois níveis adotando limiares que particionam os valores em 3 ou mais intervalos (e.g. Barrera et al. (2007) adotou quantização em 3 níveis aplicando dois limiares, um para os valores negativos e outro para os valores positivos resultantes da transformação normal via Z-Score). A partição também pode ser realizada por meio de percentis. 
Seleção de características: trata-se de uma processo de busca pelo subconjunto de características (genes preditores) que melhor representam (ou predizem o comportamento) de um objeto de interesse (gene alvo) (Figura 11d). Um método de seleção de características é composto por um algoritmo de busca e por uma função critério responsável por avaliar um dado subconjunto de características em relação a sua representação do objeto de interesse. A Seção 2.5 se dedica a discutir melhor esse processo, pois é a etapa crítica do processo de inferência de PGNs, tanto do ponto de vista computacional como do ponto de vista estatístico.

Construção da PGN: Esta etapa permite definir o número de subconjuntos preditores selecionados na etapa anterior para cada alvo que compõe a PGN, além de derivar famílias de PGNs com números diferentes de subconjuntos por alvo (Figura 11e).

A Figura 13 exemplifica este processo para o alvo $Y$ que inclui: (a) seu melhor subconjunto preditor $\left\{x_{1}, x_{2}, x_{3}\right\}$; (b) seus dois melhores subconjuntos de preditores $\left\{\left\{x_{1}, x_{2}, x_{3}\right\},\left\{x_{4}\right\}\right\}$; e (c) os três melhores subconjuntos de preditores $\left\{\left\{x_{1}, x_{2}, x_{3}\right\},\left\{x_{4}\right\}\right.$, $\left\{x_{5}, x_{6}\right\}$.

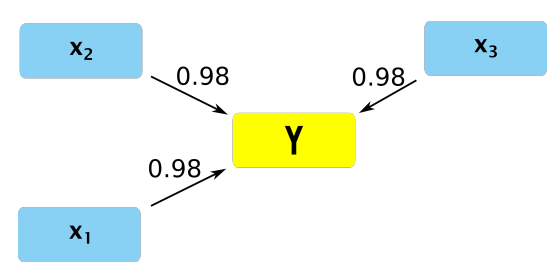

(a)

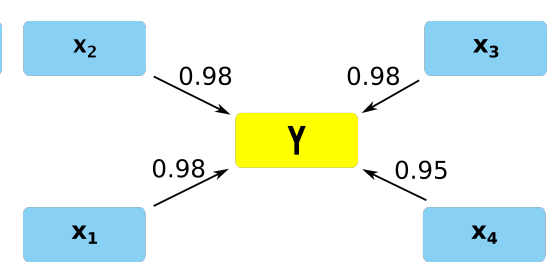

(b)

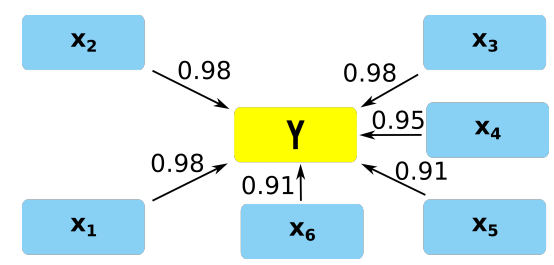

(c)

Figura 13. Três exemplos com diferentes números de subconjuntos para o gene alvo $Y$ : (a) o melhor subconjunto preditor $\left\{x_{1}, x_{2}, x_{3}\right\}$; (b) dois subconjuntos de preditores $\left\{\left\{x_{1}, x_{2}, x_{3}\right\},\left\{x_{4}\right\}\right\}$; (c) três subconjuntos de preditores $\left\{\left\{x_{1}, x_{2}, x_{3}\right\},\left\{x_{4}\right\},\left\{x_{5}, x_{6}\right\}\right\}$. As arestas representam os valores da função critério atribuídos aos subconjuntos preditores em relação ao gene alvo.

Uma vez definidos os subconjuntos de preditores finais para cada alvo, as lógicas de dependência que regem o perfil de expressão do alvo são derivadas com base nesses subconjuntos (Figura 16b). Estas lógicas são obtidas através das distribuições de probabilidades condicionais $P(Y \mid \mathbf{Z})$ (onde $Y$ é o alvo e $\mathbf{Z}$ é um subconjunto de candidatos a preditores para $Y$ ). O processo de obtenção dessas tabelas de distribuições de probabilidades condicionais, bem como a derivação da regra lógica de predição do gene alvo 
a partir dessas distribuições, serão descritos na Seção 2.5, já que isso é parte inerente do processo de seleção de características. Ao final da etapa de construção de PGN, tem-se então o resultado final (Figura 11f): a PGN com a topologia da rede com os genes preditores conectados aos respectivos genes alvos e as respectivas regras lógicas que regem as expressões dos genes alvos com base nos seus preditores.

\subsection{Seleção de Características}

É importante destacar que a seleção de características é uma das etapas cruciais para a inferência de GRNs modeladas por redes gênicas probabilísticas (PGN), conforme já mencionado na Seção 2.4.5. Essa etapa tem como objetivo buscar interações entre genes que sejam potencialmente interessantes sob o ponto de vista biológico, a partir das observação de suas expressões, delimitando o número de potenciais interações.

Em experimentos de bioinformática, normalmente há um alto custo financeiro, humano e de tempo associado a análise e validação biológica em bancada (wet-lab). A ideia então é fornecer a um especialista a visualização de um conjunto reduzido de potenciais interligações entre genes, facilitando a geração e corroboração de hipóteses sobre um determinado fenômeno de interesse (LOPES, 2011).

Nesse contexto, métodos de seleção de características são aplicados basicamente para identificar subconjuntos de genes que melhor predizem o estado de um gene alvo de acordo com alguma função critério que atribui um valor de qualidade para os subconjuntos de preditores candidatos de acordo com os seus perfis de expressão em relação ao perfil de expressão do alvo (BARRERA et al., 2007; BORELLI et al., 2013; LOPES et al., 2014).

Um método de seleção de características é composto por duas partes principais: uma estratégia de busca para selecionar subconjuntos candidatos a preditores e uma função critério que avalia esses candidatos com base na qualidade de predição do comportamento de um objeto de interesse.

Existem muitos algoritmos de seleção de características propostos na literatura, a maioria deles computacionalmente eficientes, porém sub-ótimos (LOPES, 2011). De fato, em geral o único algoritmo que garante a otimalidade é a busca exaustiva (COVER; VAN-CAMPENHOUT, 1977), embora seu custo computacional seja proibitivo na maioria dos casos, e em especial em problemas com alta dimensionalidade, como é o caso da inferência de GRNs. O fato da busca exaustiva ser o único a garantir a solução ótima deve-se ao efeito nesting que ocorre com os algoritmos sub-ótimos. Tais 
algoritmos buscam por uma solução sub-ótima adicionando ou removendo características uma por vez, porém às vezes uma característica que faz parte da solução atual, mas que não faz parte da solução ótima, pode nunca mais ser removida do conjunto solução. Além disso, pode ser que uma característica nunca seja adicionada ao conjunto solução atual, mesmo que ela faça parte da solução ótima (PUDIL; NOVOVICOVÁ; KITTLER, 1994).

O efeito nesting pode ser explicado pelo fato de que duas características em conjunto podem realizar uma predição ou classificação adequada da classe (ou valor) do objeto alvo, apesar das suas predições ou classificações individuais sobre o objeto alvo serem ruins. Por outro lado, duas características muito boas individualmente podem dar origem a um par de características que não é tão boa para predizer ou classificar o objeto alvo. Isso tende a ocorrer especialmente se essas características são altamente correlacionadas, ou seja, redundantes (PENG; LONG; DING, 2005). De fato, nada impede que esse par seja pior em predizer o comportamento do objeto alvo do que um par cujas características individuais sejam ruins. Este fenômeno é chamado de sinergia, regulação combinatória, ou predição intrinsecamente multivariada (IMP) (ANASTASSIOU, 2007; MARBACH et al., 2010; MARTINS-JR et al., 2008; MARTINS-JR et al., 2013). Tal fenômeno é ilustrado na Figura 14.

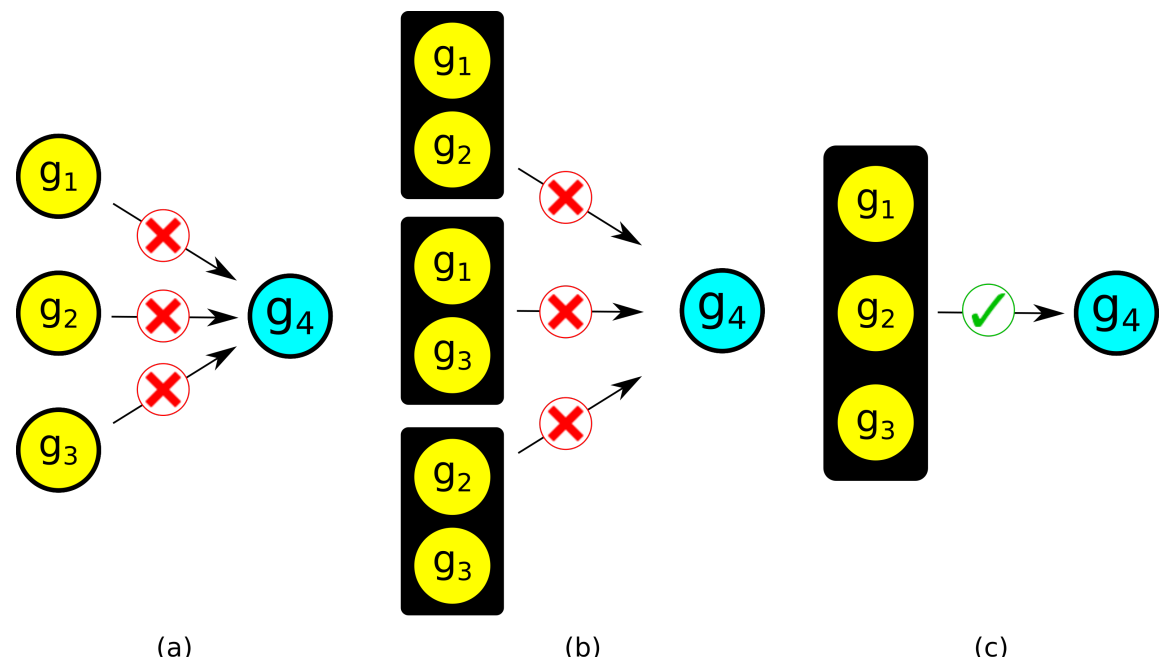

(a)

(b)

(c)

Figura 14. Ilustração do conceito de predição intrinsecamente multivariada para o caso de 3 preditores e 1 alvo: (a) Preditores tomados isoladamente não predizem o comportamento do alvo; (b) Preditores tomados aos pares também não realizam uma boa predição; (c) A tripla $\left[g_{1}, g_{2}, g_{3}\right]$ é um excelente preditor de $g_{4}$ (gene alvo). Fonte: (MARTINS-JR, 2008) - adaptado.

Formalmente, um subconjunto de características $\mathbf{Z}$ é considerado IMP dado um gene alvo $Y$ se o comportamento de $Y$ é fortemente predito pelo comportamento de $\mathbf{Z}$ e, ao mesmo tempo, fracamente predito por qualquer subconjunto próprio $\mathbf{Z}^{\prime} \subset \mathbf{Z}$. Nesse sentido, a força de predição intrinsecamente multivariada IMP Score (IS)), é 
definida como (MARTINS-JR et al., 2008):

$$
I S(\mathbf{Z}, Y)=\mathcal{J}(\mathbf{Z}, Y)-\max _{\mathbf{Z}^{\prime} \subset \mathbf{Z}} \mathcal{J}\left(\mathbf{Z}^{\prime}, Y\right)
$$

onde $\mathcal{J}($.) é a função critério escolhida para avaliar a dependência de uma variável alvo $Y$ em relação a um conjunto de características $\mathbf{Z}$ (valores mais altos implicam maior dependência). Se $I S(\mathbf{Z}, Y)=0$, então certamente há pelo menos uma variável redundante em $\mathbf{Z}$, implicando que $\mathbf{Z}$ deve ser reduzido ( $\mathbf{Z}$ definitivamente não é IMP em relação ao alvo).

Também é possível definir um limiar positivo para decidir se um conjunto de características é IMP ou não em relação ao alvo. No caso do par $(\mathbf{Z}, Y)$ não ser IMP, $\mathbf{Z}$ pode ser reduzido a um de seus próprios subconjuntos $\left(\mathbf{Z}^{\prime} \subset Z\right)$ que apresente o maior valor $\mathcal{J}($.$) . Este processo é recursivo: a redução é aplicada até que a pontuação IMP$ do par atual $\left(\mathbf{Z}^{\prime}, Y\right)$ seja maior que um dado limiar ou $\mathbf{Z}^{\prime}=\emptyset$.

Em relação às funções critério usualmente envolvidas na seleção de características para inferência de PGNs, pode-se mencionar três frequentemente utilizadas:

- Coeficiente de Correlação de Pearson: dois genes recebem uma aresta entre si caso a correlação entre seus perfis de expressão seja maior que um limiar (LANGFELDER; HORVATH, 2008; COSTA et al., 2011). Métodos baseados em correlação consideram apenas relacionamentos 1 para 1 , sendo adequados para identificar corregulação ou coexpressão, módulos funcionais ou agrupamentos entre os genes. Porém, é ignorado o fato de que a expressão de um determinado gene pode ser regulada por um grupo de genes de forma multivariada. Também não provê qualquer noção de causalidade.

- Coeficiente de Determinação (CoD): $\mathrm{CoD}$, utiliza uma estimação do erro Bayesiano dos preditores ao classificar o perfil de expressão do alvo, onde é possível estimar relações multivariadas entre um grupo de preditores e um gene alvo ( $N$ para 1) (DOUGHERTY; KIM; CHEN, 2000; DOUGHERTY et al., 2009). Trata-se de um critério popularmente usado em inferência de redes gênicas (MARTINS-JR et al., 2008; LOPES; MARTINS-JR; CESAR-JR, 2008a; DOUGHERTY et al., 2009; LOPES et al., 2014). O CoD de um alvo $Y$ dado um conjunto de candidatos a preditores $(\mathbf{Z})$ é dado por:

$$
\operatorname{CoD}_{Y}(\mathbf{Z})=\frac{\varepsilon_{Y}-\varepsilon_{Y}(\mathbf{Z})}{\varepsilon_{Y}}
$$

onde $\varepsilon_{Y}=1-\max _{y \in Y} P(y)$ é o erro ao prever $Y$ na ausência de outras observações 
e $\varepsilon_{Y}(\mathbf{Z})=1-\sum_{\mathbf{z} \in \mathbf{Z}} \max _{y \in Y} P(\mathbf{z}, y)$ é o erro ao prever $Y$ baseado na observação de $\mathbf{Z}$. $C o D=0$ significa que o subespaço de características é irrelevante para a predição de $Y$, enquanto $C o D=1$ significa que o subespaço de características em questão prediz (classifica) perfeitamente os valores de $Y$.

- Informação Mútua (IM): IM é baseada na entropia de Shannon, também é frequentemente aplicada em métodos de inferência de GRNs (LIANG; FUHRMANE; SOMOGYI, 1998; BARRERA et al., 2007; LOPES; MARTINS-JR; CESAR-JR, 2008a; BORELLI et al., 2013; LOPES et al., 2014; MONTOYACUBAS et al., 2015). Assim como o CoD, IM também é capaz de capturar relações multivariadas (relacionamentos $N$ para 1) (ZHANG; HORVATH, 2005; BARMAN; KWON, 2017). A informação é definida pela diferença entre a entropia a priori de $Y$ e a entropia condicional de $Y$ dado $\mathbf{Z}$, conforme abaixo,

$$
I M(\mathbf{Z}, Y)=H(Y)-H(Y \mid \mathbf{Z})
$$

sendo $H(Y)$ definido por:

$$
H(Y)=-\sum_{y \in Y} P(y) \log P(y)
$$

e $H(Y \mid \mathbf{Z})$ é a entropia condicional média de $Y$ dados os valores de $\mathbf{Z}$ definida por:

$$
H(Y \mid \mathbf{Z})=-\sum_{\mathbf{z} \in \mathbf{Z}} P(\mathbf{z}) \sum_{y \in Y} P(y \mid \mathbf{z}) \log P(y \mid \mathbf{z})
$$

sendo ainda $P(\mathbf{z})$ a probabilidade de $\mathbf{Z}=\mathbf{z}$ e $P(y \mid \mathbf{z})$ a probabilidade de $Y=y$ dado $\mathbf{Z}=\mathbf{z}$. Vale ressaltar que quanto menor o valor de $H(Y \mid \mathbf{Z})$, maior será o ganho de informação sobre o gene alvo $Y$, através do conjunto de características $\mathbf{Z}$.

A entropia mede o grau de desordem de uma variável, sendo que quanto maior a entropia dos valores de um gene, menor sua previsibilidade, conforme ilustrado na Figura 15.

É importante notar que o CoD e IM precisam avaliar a força de predição de um subconjunto de preditores candidatos em relação ao valor de expressão do alvo com base em uma tabela de distribuição de probabilidades condicionais $P(Y \mid \mathbf{Z})$. Como o modelo PGN assume uma cadeia de Markov de primeira ordem, essa tabela é construída com base em todos os pares de instantes de tempo consecutivos (tempo 1 em relação ao 


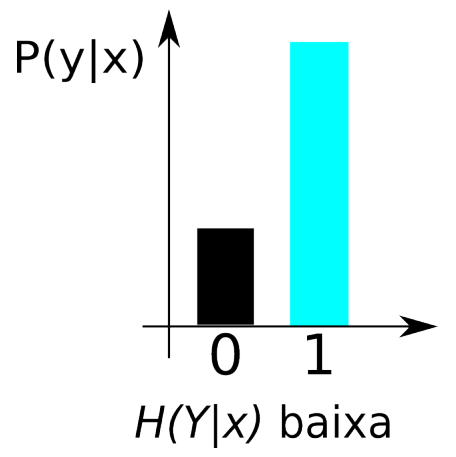

(a)

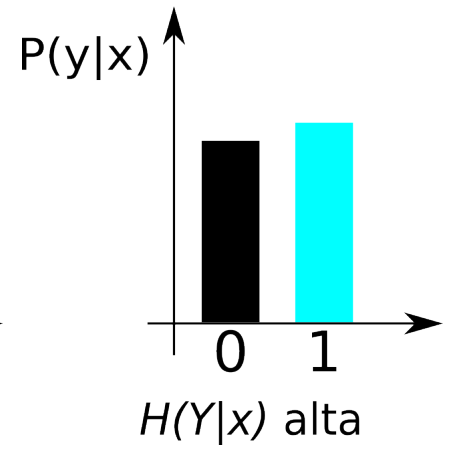

(b)

Figura 15. Histograma da entropia condicional $H(Y \mid x)$ : (a) o histograma da esquerda configura uma situação em que $\mathrm{x}$ é um bom preditor de $(\mathrm{Y})$ porque a massa de probabilidades está bem mais concentrada em $Y=1$ (entropia condicional baixa); (b) a massa de probabilidades está melhor distribuída ao longo das classes, o que faz com que $\mathrm{x}$ não seja um bom preditor de $\mathrm{Y}$ (entropia condicional alta). Fonte: (MARTINS-JR, 2008) - adaptado.

tempo 2, tempo 2 em relação ao tempo 3, e assim por diante até o tempo $M-1 \mathrm{em}$ relação ao tempo $M)$. Dessa forma, estima-se a tabela $(P(Y \mid \mathbf{Z})$ para um dado $\mathbf{Z} \subseteq \mathbf{X})$ a partir das amostras temporais de expressão gênica. A Figura 16a ilustra a obtenção dessa tabela. Depois esta tabela é avaliada por uma das funções critério que atribui uma medida qualitativa do poder de predição (ou classificação) para o subconjunto candidato a preditores $\mathbf{Z}$ em relação a um determinado alvo $Y$. Esse processo, aplicado a diversos subconjuntos candidatos a preditores conforme o algoritmo de busca escolhido resulta em uma lista de subconjuntos de preditores ordenados de acordo com a função critério adotada para o alvo $Y$.

Caso um subconjunto $\mathbf{Z}$ seja elegido para preditor de um gene alvo $Y$, a regra lógica de dependência que rege o perfil de expressão do alvo é derivada diretamente da tabela de distribuição de probabilidades condicionais $P(Y \mid \mathbf{Z})$ (vide Figura 16b) da seguinte forma: para todo $\mathbf{z} \in \mathbf{Z}$, a saída $Y$ é definida por $\left.\operatorname{argmax}_{y \in Y} P(Y=y \mid \mathbf{Z}=\mathbf{z})\right\}$, ou seja, as saídas lógicas são aquelas que minimizam o erro de classificação Bayesiano de $Y$ com base nos valores de $\mathbf{Z}$.

Como mencionado anteriormente, o ponto mais crítico do processo de inferência de GRNs baseado no modelo PGN é o algoritmo de busca da seleção de características. Embora a busca exaustiva seja a única a garantir solução ótima, não é possível realizar a busca por todo espaço de soluções, embora seja possível aplicá-la para subconjuntos de grau fixo $k$ bem pequeno, conforme foi feito por Barrera et al. (2007) para dados de expressão do Plasmodium falciparum, um parasita causador da malária, buscando por todos os subconjuntos de grau 1 ou 2. Nesse caso, é computacionalmente inviável obter subconjuntos de grau maior. Embora espera-se que a maioria dos genes não sejam 


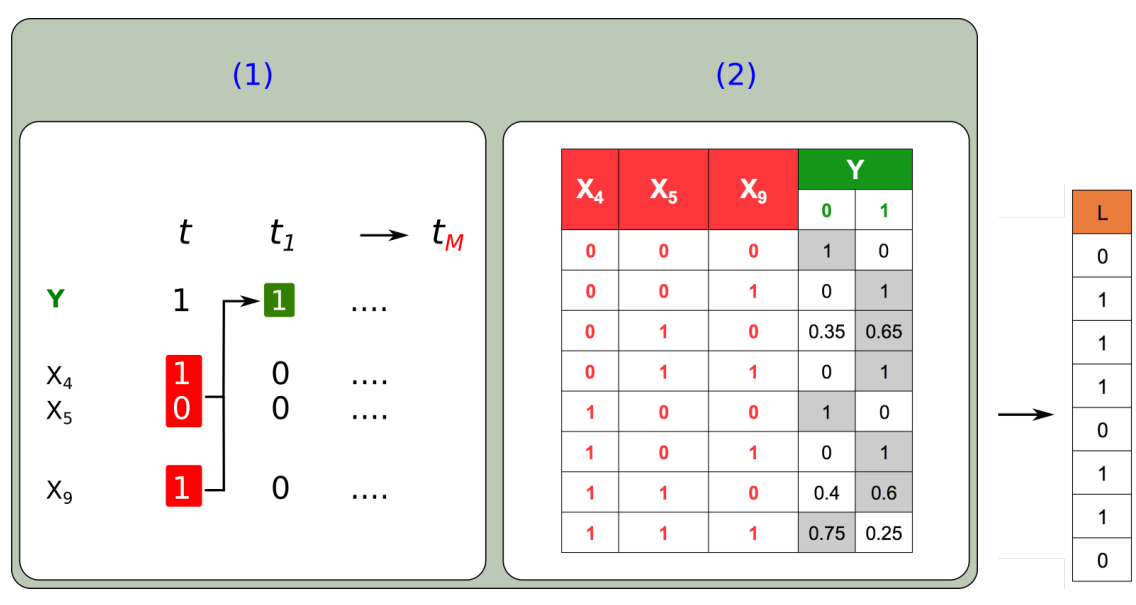

(a)

(b)

Figura 16. Exemplo de uma tabela de distribuição de probabilidades condicionais (Conditional Probability Distribution - CPD) para um dado subconjunto de genes candidatos a preditores $\left(\mathbf{Z}=\left\{X_{4}, X_{5}, X_{9}\right\} \subseteq \mathbf{X}\right)$ estimada com base nos dados quantizados: (a1) nas linhas os genes e nas colunas as amostras utilizadas para estimar a qualidade de predição de um subconjunto de genes (valores destacados em vermelho) em relação a um determinado alvo (valor destacado em verde), considerando todos os pares de instantes de tempo consecutivos (supondo uma Cadeia de Markov de primeira ordem). Como resultado: (a2) a tabela CPD de um gene alvo dados seus preditores $\left(P\left(Y \mid\left\{X_{4}, X_{5}, X_{9}\right\}\right)\right)$; (b) a partir da tabela $C P D$, é derivada uma função lógica Booleana $(L)$ que minimiza o erro Bayesiano de classificação do alvo no próximo instante de tempo (destacadas em cinza a maior probabilidade para cada linha, fazendo com que os valores de $Y$ mais prováveis componham a função $L$ ). A tabela CPD é avaliada por uma função critério para atribuir a qualidade desse subconjunto em relação ao alvo.

regulados por muitos preditores, existem genes que podem possuir um conjunto maior de reguladores, especialmente hubs. Para tentar obtê-los, pode-se aplicar algoritmos subótimos como já proposto por Lopes, Martins-Jr and Cesar-Jr (2008a) e Lopes et al. (2014), este último especificamente projetado para detectar hubs. Mesmo assim, pelo problema crônico de falta de amostras, aliado à maldição da dimensionalidade (JAIN; DUIN; MAO, 2000), há a tendência de se obter muitos conjuntos empatados em primeiro lugar, de acordo com a função critério. Isso também tende a resultar em genes redundantes nos subconjuntos preditores resultantes que agregam muito pouca ou nenhuma informação em relação ao perfil de expressão do gene alvo.

Para amenizar os problemas supracitados, o arcabouço proposto a ser apresentado no Capítulo 3 introduz uma etapa anterior à seleção de características que consiste em agrupar genes com perfis semelhantes de acordo com algum critério. Isso ocasiona dois efeitos positivos:

1. Reduzir drasticamente a dimensionalidade ao aplicar a seleção de características, já que os candidatos a preditores ficam restritos apenas aos genes representantes dos grupos resultantes. Isso permite uma aplicação eficiente de busca exaustiva 
por subconjuntos de preditores de grau maior $(3,4$ ou 5$)$;

2. Reduzir bastante a possibilidade de haver genes redundantes em um mesmo conjunto preditor;

Sendo assim, a próxima seção (Seção 2.6) discute conceitos a respeito do agrupamento e métodos popularmente adotados para tal.

\subsection{Agrupamento}

Investigações relacionadas à modelagem e identificação de redes de genes vem sendo abordadas na literatura, porém analisar uma grande quantidade de dados biológicos, tentando identificar genes relevantes para um modelo de predição com mecanismos responsáveis por fenômenos biológicos como um todo ainda é uma tarefa difícil. A interpretação dos dados agrupados (clusters) que combinem perfis similares visando a redução da dimensionalidade pode ser bem apropriada para uma etapa futura de inferência por seleção de características que busque identificar atributos que auxiliem a revelar a estrutura das redes gênicas (DOUGHERTY, 2005).

Alguns trabalhos partem do pressuposto que os grupos de objetos sejam conhecidos, buscando características nesse dados que evidenciem a separação desses objetos nos grupos correspondentes. Tais trabalhos são de classificação supervisionada. Porém, frequentemente os grupos não são conhecidos, incluindo a quantidade de grupos existentes nos dados. Nesse caso, agrupam-se os objetos de acordo com a similaridade deles baseada em suas características. Esse tipo de classificação é conhecido como classificação não-supervisionada, também conhecido como agrupamento (clustering) (RUSSELL; NORVIG, 2016), e será o foco da presente seção.

Dados de expressão gênica podem ser agrupados com base nos genes (perfis de expressão gênica ao longo das amostras), amostras (perfis das amostras compostos pelas expressões dos genes) ou ambos ao mesmo tempo (bi-clusterização, co-clusterização ou clusterização em dois modos) (GOVAERT; NADIF, 2013). Cada tipo de agrupamento possui aplicações específicas e apresenta desafios particulares. Algumas das abordagens mais populares são: Self-Organizing Map (SOM), k-means, Hierarchical, Fuzzy $C$-Means, entre outros, sendo que os resultados produzidos por eles podem diferir bastante em alguns casos (HU; YOO, 2004; DEFAY et al., 2012). Algoritmos de agrupamento são geralmente classificados como particionais, hierárquicos ou híbridos. A Figura 17 ilustra uma taxonomia de classificação das principais abordagens de agrupamento. 


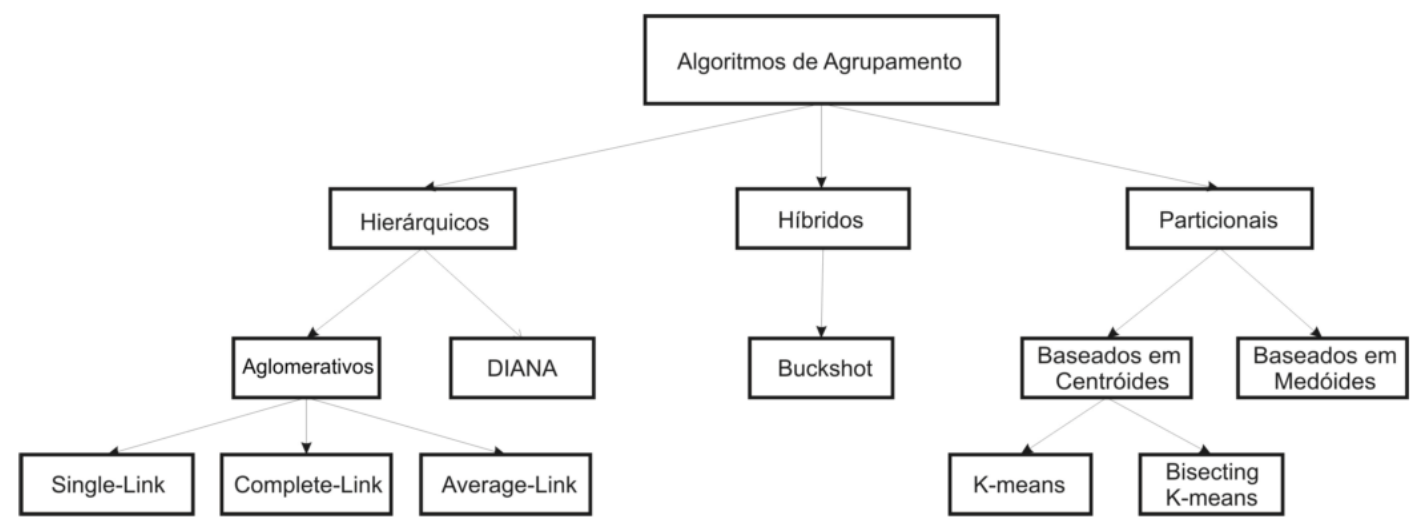

Figura 17. Taxonomia de classificação de algoritmos de agrupamento. Fonte: (FAHAD et al., 2014) - adaptado.

O algoritmo k-means é um dos algoritmos de agrupamento mais popularmente adotados em aplicações científicas e industriais (BERKHIN, 2006). A Figura 18 exemplifica a execução deste algoritmo (MACQUEEN et al., 1967; LLOYD, 1982). Ele utiliza o conceito de centróides como protótipos para representar o centro de um grupo, calculado pela média de todos os objetos do grupo, e particiona $n$ observações em $k$ grupos com base em uma amostra. Cada observação pertencente ao grupo tem seu valor mais próximo da média do seu grupo do que das médias dos outros grupos. Geralmente inicia-se os $k$ valores das centróides aleatoriamente em duas etapas:

1. Uma etapa de alocação, onde todas as amostras são alocadas em um grupo contendo o centróide que produz a menor soma dos quadrados das distâncias dentro desse grupo.

2. Uma etapa de representação, onde uma nova centróide é definida para cada grupo, isto é, novas médias são calculadas para serem centróides das amostras nos novos agrupamentos (PINDAH et al., 2015).

Posteriormente o algoritmo repete esses passos até que os agrupamentos se estabilizem, ou seja, que as alterações nos grupos cessem ou que um determinado número de iterações seja alcançado.

A partir de um conjunto de dados finitos $X=x_{i}, i=1, \cdots, n$ com $n$ objetos a serem agrupados em $k$ grupos, $C=c_{k}, k=1, \cdots, K$ o algoritmo $k$-means controla as mudanças dos vetores $x_{i}$ entre os grupos $c_{k}$ através de uma função objetivo de agrupamento baseada em centróide (FILIPPONE et al., 2008). A centróide pode variar, dependendo da função objetivo de agrupamento, podendo ser uma medida de dissimilaridade ou distância (usualmente a distância Euclideana), e como resultado espera-se 


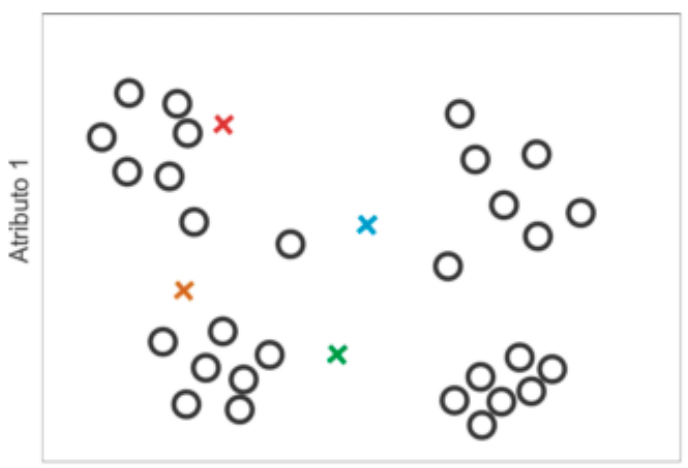

Atributo 2

(a) Passo 1 - Sorteio dos valores iniciais dos centróides

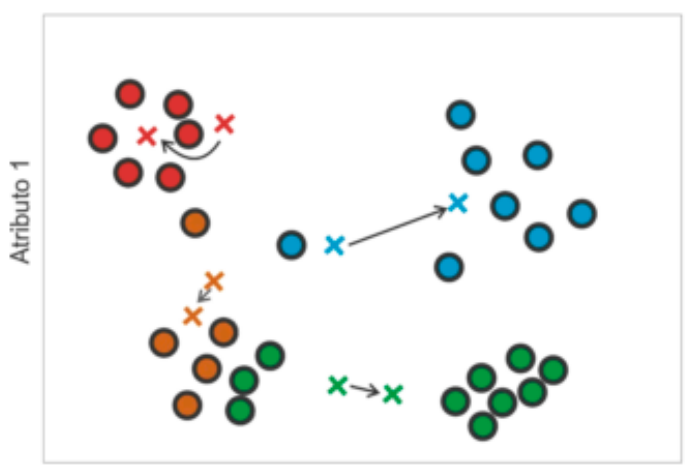

Atributo 2

(c) Passo 3 - Recalcula os valores dos protótipos como sendo a média dos objetos atuais pertencentes aos grupos.

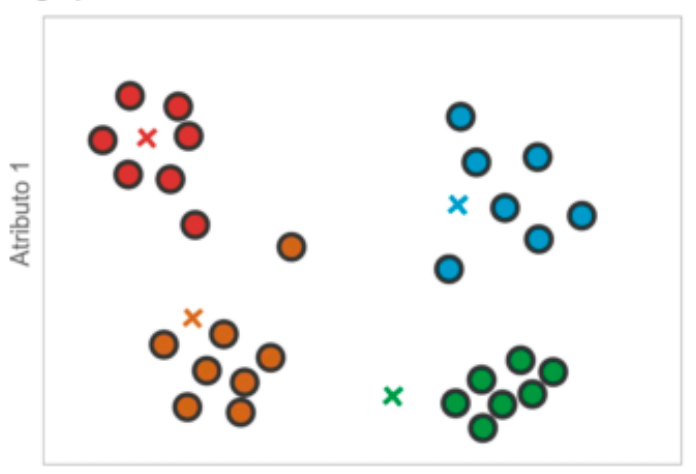

Atributo 2

(e) Repetição do passo 2 - Atribuição dos objetos aos grupo cujo protótipo possua maior similaridade.

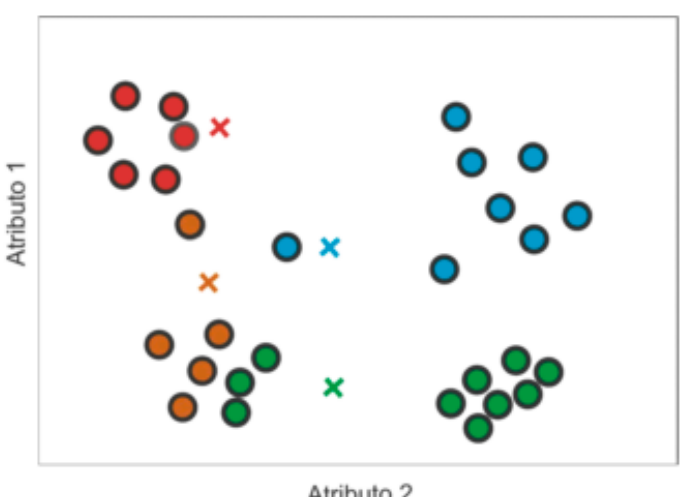

Atributo 2

(b) Passo 2 - Atribuição dos objetos aos grupos cujo protótipo possua maior similaridade.

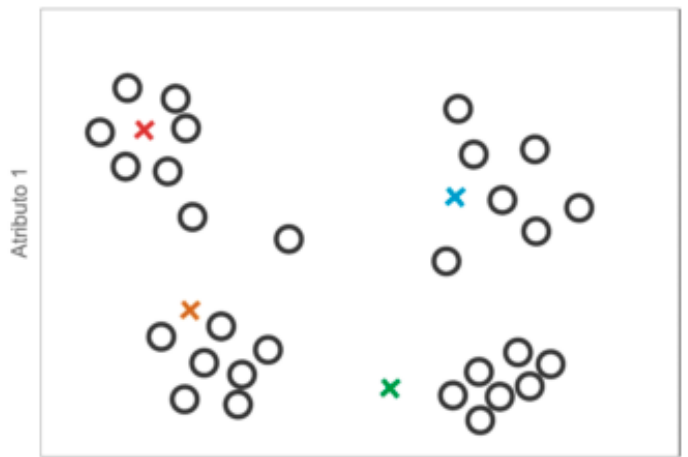

Atributo 2

(d) Preparação para repetição dos passos 2 e 3 Desvincula-se os objetos dos grupos.

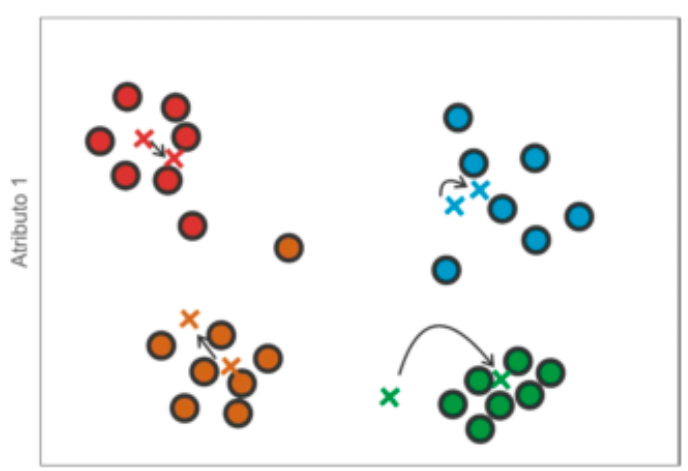

Atributo 2

(f) Repetição do passo 3 - Recalcula os valores dos protótipos como sendo a média dos objetos atuais pertencentes ao grupo.

Figura 18. Exemplo de execução do algoritmo k-means. Fonte: (FONTANA; NALDI, 2009) adaptado.

um agrupamento de forma esférica. Por padrão, esse algoritmo busca minimizar a soma dos quadrados dos erros (SSE) do $k$-ésimo grupo como medida de qualidade para cada agrupamento, também conhecida como medida de coesão. definida pela 
Equação 2.11:

$$
S S E=\sum_{k=1}^{K} \sum_{x \in c_{k}}(x-\bar{x})^{2}
$$

em que $c_{k}$ é o $k$-ésimo grupo e $\bar{x}$ a média do $c_{k}$.

Outras métricas têm sido aplicadas para avaliar o quanto os agrupamentos estão coesos, como Critério de Informação Bayesiana (BIC) ou Critério de Informação Akaike (AIC), entre outras (BERKHIN, 2006).

O algoritmo $k$-means foi elegido pelo arcabouço desenvolvido para inferência de PGNs (vide Capítulo 3) não apenas por ser popular, mas também por ser um algoritmo particional, ou seja, um método que devolve uma partição (grupos de objetos sem interseção entre si). Isso porque o arcabouço proposto só funciona a partir de uma partição dos genes de modo que nenhum gene pertença a mais de um grupo. De qualquer modo, por ser um arcabouço, admite-se a aplicação de qualquer método particional, não se restringindo apenas ao algoritmo $k$-means. 
Capítulo 2

\section{Abordagem proposta para inferência de redes gênicas probabilísticas}

Este capítulo detalha um novo framework para inferência de redes gênicas baseado em agrupamento, busca exaustiva e análise multivariada, denominado GeNICE: a novel framework for Gene Networks Inference by Clustering, Exhaustive search and multivariate analysis (JACOMINI et al., 2016; JACOMINI et al., 2017).

O GeNICE segue o modelo PGN proposto por (BARRERA et al., 2007) e evolui o fluxograma de inferência de PGNs típico apresentado na Seção 2.4.5, introduzindo o agrupamento como uma etapa anterior à etapa de seleção de características, e uma etapa posterior de análise multivariada para eliminar possíveis genes preditores redundantes em relação a predição dos genes alvos. A Figura 19 apresenta uma visão geral do fluxo de trabalho do framework, cujos módulos são detalhados a seguir.

\subsection{Dados de Expressão Gênica}

O GeNICE toma como entrada (Figura 19a) um conjunto de dados (série temporal) de perfis de expressão gênica em uma matriz $N \times M$, com $N$ genes e $M$ instantes de tempo consecutivos, conforme já mencionado na Seção 2.4 .5 e exemplificado na Figura 12a. 


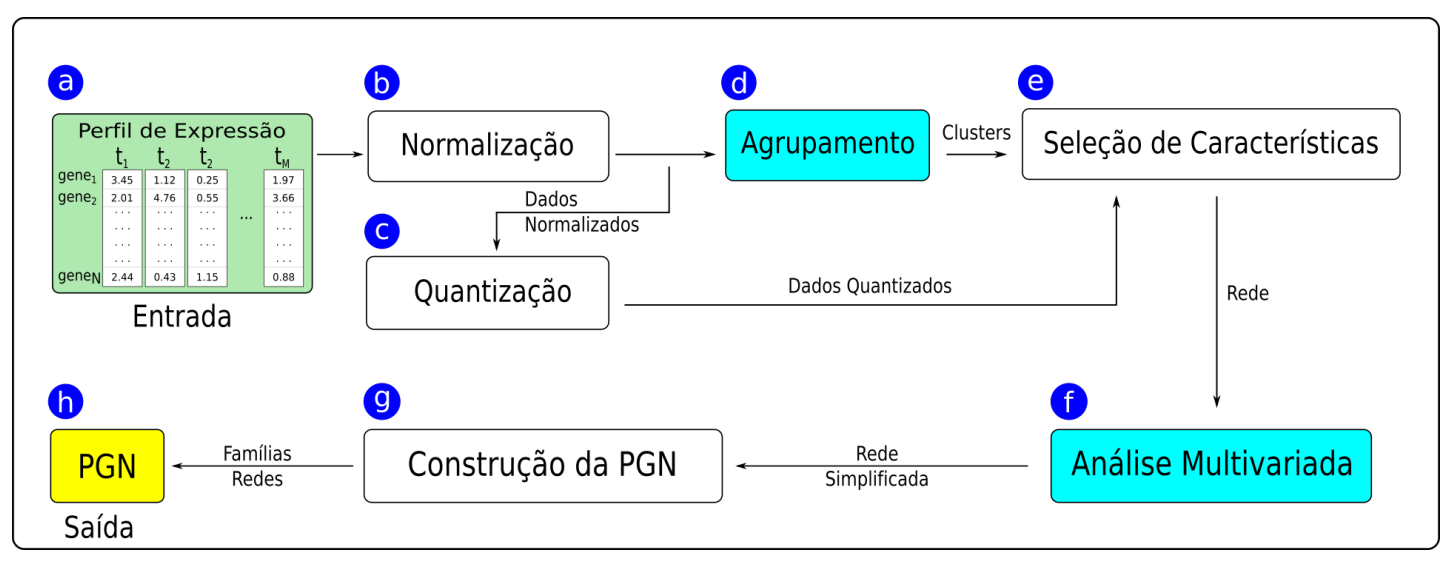

Figura 19. As principais etapas envolvidas no framework GeNICE para inferir redes gênicas seguindo o modelo de Redes Gênicas Probabilísticas (PGN). A caixa em verde (a) representa a entrada de dados (dados de expressão gênica), e a caixa amarela (h) representa a rede PGN inferida como o resultado final. As etapas (d) e (f) de agrupamento e análise multivariada, respectivamente as caixas na cor azul, são as novas etapas introduzidas em relação ao que usualmente era feito anteriormente.

\subsection{Normalização}

Para normalizar os perfis de expressão dos genes de forma que eles sejam comparáveis (Figura 19b), adotou-se o Z-Score conforme previamente definido na Seção 2.4.5, Equação 2.5.

\subsection{Quantização}

Uma vez que o GeNICE segue o modelo PGN, o conjunto de dados de expressão gênica deve ser quantizado de tal maneira que o dado de expressão gênica apresente um conjunto finito de valores possíveis (Figura 19c). Para isso os valores negativos resultantes do processo de normalização via Z-Score se tornam 0 , enquanto os valores positivos se tornam 1 (valores binários). Um exemplo do resultado desta etapa foi apresentado na Seção 2.4.5, Figura 12b.

Outros valores também podem ser adotados, desde que tenham amostras suficientes para uma boa estimativa dos parâmetros do modelo. Um exemplo é a quantização ternária que pode ser mapeada da seguinte forma: Quantiza-se os dados baseado na transformação normal, fazendo com que a média de cada sinal tenha valor zero. Dessa forma, valores subexpressos (-1) serão aqueles que estivessem abaixo da média dos valores negativos e os superexpressos $(+1)$ serão aqueles acima da média dos valores positivos. Os valores próximos à média (acima da média dos negativos e ao mesmo tempo abaixo da média dos positivos) serão considerados como valores normais (0). 


\subsection{Agrupamento}

O GeNICE foca em clusterização por genes. A etapa de agrupamento (Figura 19d) que precede a seleção de características é uma das principais novidades da nossa proposta. Esta etapa é importante para reduzir a dimensionalidade de possíveis genes preditores para cada gene alvo de interesse (ordem de milhares) para uma grandeza da ordem do número de clusters resultantes $k$ (idealmente na ordem de dezenas). Com isso, pode haver um grande impacto no processo de seleção de características (ver Seção 3.5), uma vez que o número de clusters (grupos) ( $k$ ) torna-se a dimensionalidade resultante do processo de inferência pela seleção de características e pode assim reduzir drasticamente o número de combinações calculadas dependendo do algoritmo de seleção de características aplicado.

Após a normalização, os dados temporais são agrupados por genes com os valores de expressão similares. Qualquer técnica de agrupamento que devolva uma partição (lista de genes disjuntas, uma para cada grupo), incluindo o gene representante de cada grupo, pode ser aplicada.

O GeNICE aplica uma variante do algoritmo $k$-means nos dados de entrada, inicializando o valor do $k$ inicial predefinido de forma que a soma das dissimilaridades em cada grupo seja mínima, eliminando assim a estocasticidade do algoritmo $k$-means. Esse procedimento segue a primeira etapa do algoritmo proposto por Kaufman and Rousseeuw (1987). Com essa inicialização o agrupamento fica menos sensível e robusto em relação a ruídos e outliers. Posteriormente, para guiar e avaliar a qualidade dos agrupamentos, duas medidas são aplicadas: distância Euclideana e correlação absoluta de Pearson. A medida escolhida é muito importante porque define diferentes tipos de semelhança entre os perfis de expressão gênica em um mesmo grupo. Por exemplo, as Figuras 20a e 20b representam os sinais de expressão gênica pertencentes ao mesmo grupo de acordo com a distância Euclidiana e a correlação absoluta de Pearson, respectivamente. Em particular, a correlação absoluta de Pearson tende a agrupar genes cujos perfis de expressão apresentam formas semelhantes e fases iguais e opostas em um agrupamento. Este critério é mais desejável do que a correlação de Pearson ou a distância Euclidiana com o propósito específico de derivar os melhores preditores para um determinado gene alvo, uma vez que os preditores candidatos fortemente correlacionados (positivamente ou negativamente) tendem a ser redundantes entre si. Assim, genes com fortes correlações negativas que compõem o mesmo grupo não podem participar do mesmo subconjunto de preditores para um dado alvo, uma vez que é admitido apenas um gene representante para cada agrupamento (e apenas este gene pode ser um candidato a preditor no arcabouço proposto). 


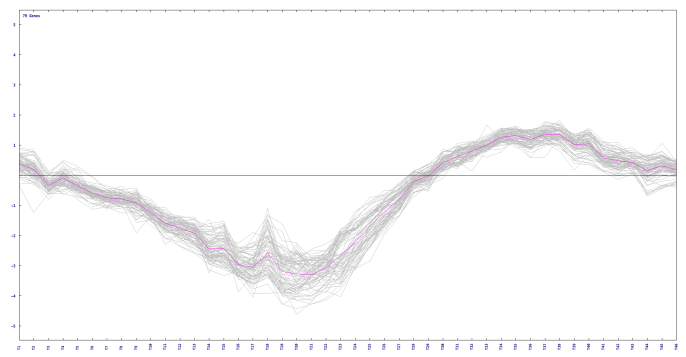

(a)

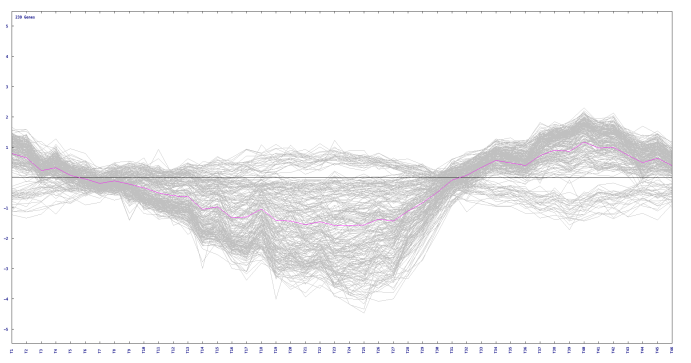

(b)

Figura 20. Agrupamentos de perfis de expressão gênica com o mesmo padrão (mesma forma do sinal) (AZUAJE; DOPAZO, 2005): (a) distância Euclidiana; (b) correlação absoluta de Pearson.

Uma vez definidos os grupos, somente um gene representante deve ser selecionado para cada grupo. Ao utilizar a distância Euclideana como critério de agrupamento, o gene representante de um grupo é aquele cujo perfil de expressão possui a menor distância Euclidiana para o centróide (média do grupo). Por sua vez, ao aplicar a correlação absoluta de Pearson como critério, elege-se o representante como o gene que tiver a maior média de correlação absoluta de Pearson de seu perfil de expressão com os perfis dos demais genes do grupo. Ao final da etapa de agrupamento, apenas os genes representantes $\mathbf{C}=\left\{C_{1}, C_{2}, \ldots, C_{k}\right\} \subseteq \mathbf{X}$ (um por grupo) compõem o conjunto de preditores candidatos a serem considerados na etapa de seleção de características, onde $\mathbf{X}$ é o conjunto de genes (com cardinalidade $N$ ), $\mathbf{C}$ é o conjunto de preditores candidatos (com cardinalidade $k$ ), e $C_{i}$ é o gene representante do agrupamento $i$.

\subsection{Seleção de Caraterísticas}

Como o GeNICE adota o modelo PGN para representar as redes gênicas, aplica-se um algoritmo de seleção de características para cada gene alvo visando descobrir o melhor subconjunto preditor para o gene alvo segundo uma determinada função critério. Os genes candidatos a preditores, nesse caso, são apenas os genes representantes $\mathbf{C}=\left\{C_{1}, C_{2}, \ldots, C_{k}\right\} \subseteq \mathbf{X}$ (um gene por grupo definido na etapa de agrupamento), sendo que os demais genes são ignorados como potenciais candidatos a preditores. Ao considerar apenas os $k$ representantes de grupos como candidatos a preditores, torna-se factível aplicar uma busca exaustiva considerando subconjuntos com uma dada dimensão fixa $p$ de forma a garantir que o melhor subconjunto seja obtido. Nesse sentido, é importante observar que se o número de agrupamentos definido for pequeno o suficiente, então é viável realizar uma busca exaustiva em subconjuntos de preditores em trios ou mesmo com dimensões maiores ( $p=4$ ou mesmo $p=5$ ). 
Para avaliar os subconjuntos, foram adotadas duas funções critério popularmente usadas em métodos de inferência de redes gênicas com base em seleção de características (MARTINS-JR et al., 2008; LOPES et al., 2014): (i) Coeficiente de Determinação $(\mathrm{CoD})$, baseado no erro de inferência Bayesiana (DOUGHERTY; KIM; CHEN, 2000) (vide Equação 2.7; e (ii) Informação Mútua (MI), baseado na entropia de Shannon (BARRERA et al., 2007; LOPES; MARTINS-JR; CESAR-JR, 2008a) (vide Equação 2.8)). Ambas as funções critério, bem como o processo de construção da tabela de distribuição de probabilidades condicionais da qual elas dependem, foram devidamente apresentadas na Seção 2.5.

No entanto, não basta selecionar os melhores subconjuntos de preditores com tamanho fixo $p$ para cada gene alvo, uma vez que genes redundantes podem estar presentes nesses subconjuntos. Então se faz necessário realizar uma análise multivariada desses preditores a fim de reduzir o número de preditores por alvo, simplificando assim a rede inferida. A seção seguinte (Seção 3.6) discute o processo de análise multivariada, a qual é uma novidade em relação ao processo de inferência de PGNs tradicional. Tal etapa serve justamente para descartar subconjuntos de genes similares em termos de expressão, aliviando assim o processo de busca exaustiva pura.

\subsection{Análise Multivariada}

A etapa de análise multivariada é necessária para eliminar genes redundantes dos subconjuntos de preditores $\mathbf{Z} \subseteq \mathbf{C}$ de um dado alvo $Y$. GeNICE aplica esta análise de predição intrinsecamente multivariada nos subconjuntos devolvidos pelo algoritmo de busca exaustiva para simplificar a PGN. Nos experimentos descritos no Capítulo 4 um subconjunto $\mathbf{Z}$ selecionado para predizer $Y$ é reduzido somente se $I S(\mathbf{Z}, Y)=0$ (vide Equação 2.6). Essa redução é realizada recursivamente até que $I S(\mathbf{Z}, Y) \neq 0$ ou $\mathbf{Z}=\emptyset$. A Figura 21 ilustra um exemplo de uma lista contendo subconjuntos preditores finais para cada um dos seus respectivos alvos, após a aplicação da busca exaustiva $\operatorname{com} p=3$ e a remoção dos genes redundantes.

A Figura 22b, ilustra este processo, onde é possível observar que a dupla de preditores $\left[g_{2}, g_{3}\right]$ podem predizer um alvo tão bem quanto a tripla $\left[g_{1}, g_{2}, g_{3}\right]$, sugerindo estatisticamente que o gene $g_{1}$ é redundante. 


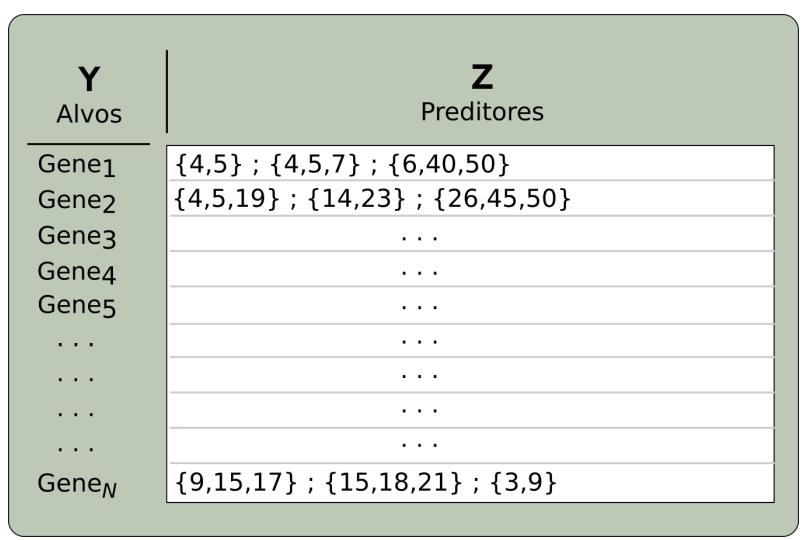

Figura 21. Exemplo de uma lista de preditores por gene alvo como resultado do processo da análise multivariada aplicado após busca exaustiva por trios $(p=3)$.

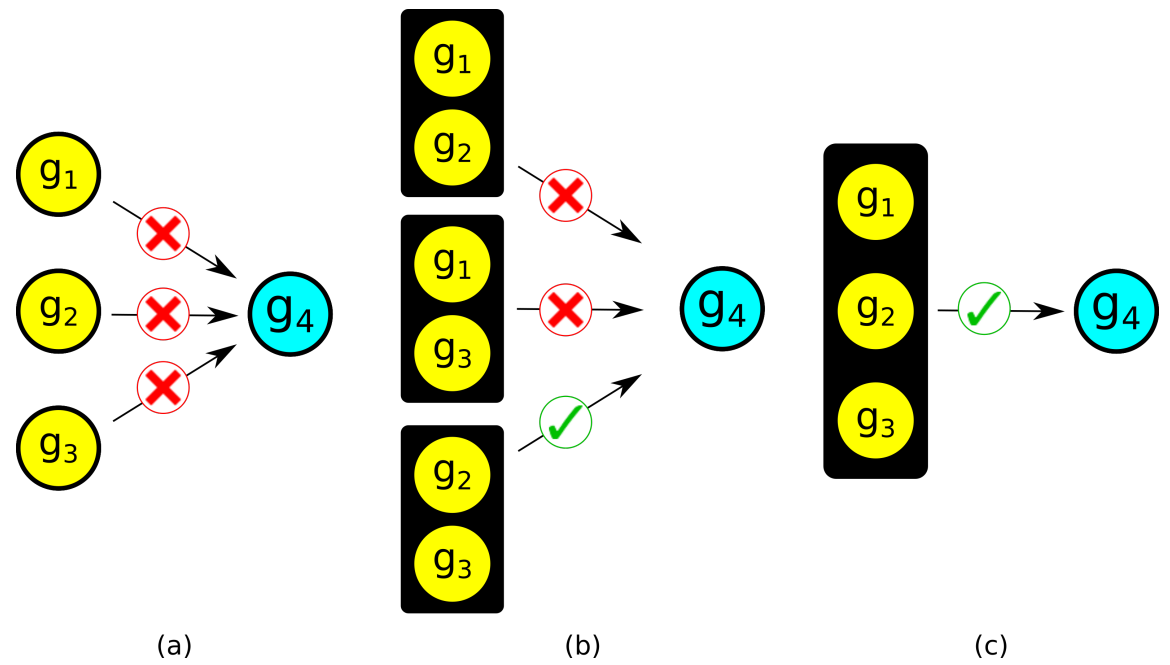

Figura 22. Ilustração da análise multivariada para o caso de 3 preditores e 1 alvo: (a) Preditores tomados isoladamente podem não predizem o comportamento do alvo; (b) Duplas de preditores podem realizar excelente predição; (c) A tripla $\left[g_{1}, g_{2}, g_{3}\right]$ é um bom preditor do gene alvo $g_{4}$.

\subsection{Construção da PGN}

Esta etapa permite definir o número de subconjuntos preditores para cada alvo que compõe a PGN, além de derivar famílias de PGNs com números diferentes de subconjuntos por alvo (Figura 19g). Funciona exatamente como já exposto na Seção 2.4.5, com a diferença que aqui os subconjuntos preditores dos alvos são obtidos da etapa de análise multivariada (e não na etapa de seleção de características como feito na abordagem original).

Nesse sentido, vale ressaltar que diferentes subconjuntos podem ter números distintos de preditores, (ex. Figuras 23a e b), uma vez que o passo anterior (análise multivariada) elimina características redundantes para obter subconjuntos com o menor número possível de preditores. 
A Figura 23 ilustra o processo de montagem final de uma PGN. As Figuras 23a, b e c, demonstram uma PGN inferida para cada gene de estudo. Os genes preditores estão representados na cor amarela e os genes de estudo (alvos) na cor azul.

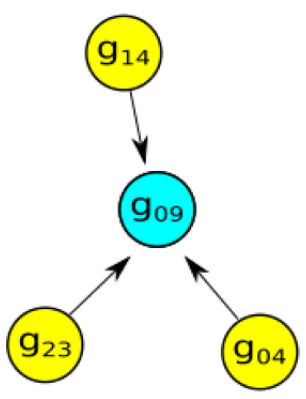

(a)

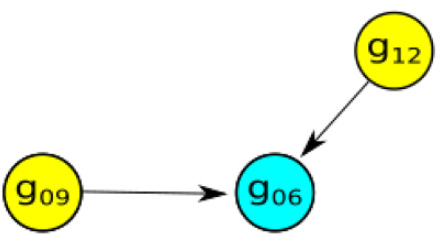

(b)

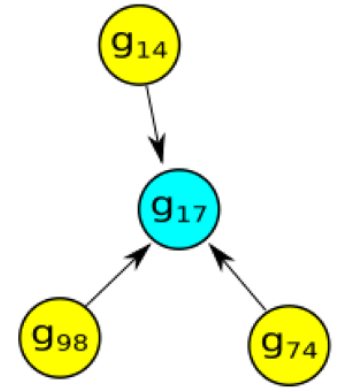

(c)

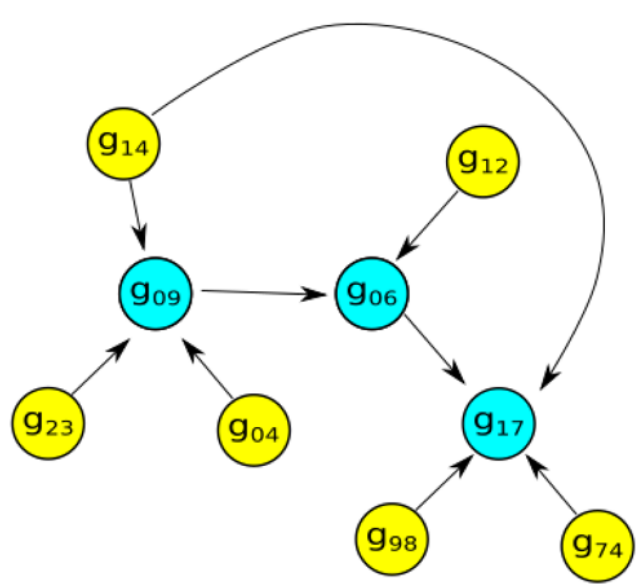

(d)

Figura 23. Construção da PGN: (a) preditores (circulo amarelo) $g_{14}, g_{32}, g_{04}$ do gene alvo (circulo azul) $g_{09}$, (b) preditores $g_{09}, g_{12}$ do gene $g_{06}$, (c) preditores $g_{14}, g_{98}, g_{74}$ do gene $g_{17} \mathrm{e}$ (d) merge das redes para os alvos $g_{09}, g_{06}$ e $g_{17}$.

Assim, a PGN final (Figura 19h) é dada pelos subconjuntos de genes representantes para cada gene alvo e suas respectivas lógicas de predição das expressões dos genes alvos. A ilustração (Figuras 23) é um exemplo desta etapa. É possível observar que o gene $g_{14}$ aparece como preditor dos alvos $g_{09}, g_{17}$, Figuras 23 a e c, e o gene $g_{09}$ mesmo sendo um gene alvo, Figura 23a, também aparece como preditor do $g_{06}$, Figura 23b. A montagem da PGN final deste exemplo, é o resultado da fusão das subredes a, b e c inferidas de forma individual para cada gene estudado como alvo, $g_{06}, g_{09}$ e $g_{17}$, e os genes $g_{09}, g_{14}$ aparecem como preditores em comum, formando uma ponte entre elas, ou seja, interconectando as subredes, Figura 23d. 


\subsection{Análise de Complexidade Computacional}

Uma das principais contribuições foi a redução da complexidade computacional do framework, no processo de busca exaustiva, na etapa de seleção de características (Figura 19d). A análise de complexidade é focada nesta etapa. As demais etapas têm um tempo de processamento insignificante em comparação a ela, uma vez que são processados em segundos mesmo para conjuntos de dados muito grandes.

Assim, a complexidade é medida de acordo com o número de vezes que a função critério é calculada durante essa etapa (então assumimos que o cálculo de função critério apresenta um tempo $O(1)$, o que é verdade para subconjuntos de preditores de cardinalidade pequena e com um numero reduzido de possíveis valores de expressão discretos).

Seja $N$ o número de genes no conjunto de dados $(N=|\mathbf{X}|), p$ um número fixo de preditores para os subconjuntos a serem avaliados e $k$ o número de agrupamentos obtidos. A complexidade de inferir a topologia da rede gênica usando a busca exaustiva é dada por: $O\left(N \times\left(\begin{array}{l}k \\ p\end{array}\right)\right)=O\left(N \times k^{p}\right)$. Uma vez que o esperado é que $k$ seja muito menor do que $N$ ( $k$ é da ordem de dezenas enquanto $N$ é da ordem de milhares), o ganho em tempo computacional é substancial quando comparado com a busca exaustiva pura, que apresenta complexidade $O\left(N \times\left(\begin{array}{l}N \\ p\end{array}\right)\right)=O\left(N^{p+1}\right)$. Por exemplo, em um conjunto de dados com $N=1000$ e $p=3$, o número de execuçoes da função critério é de aproximadamente $1,66 \times 10^{11}$ vezes para a busca exaustiva pura, e $1,66 \times 10^{8}$ para o GeNICE $\operatorname{com} k=100$ (três ordens de magnitude a menos).

\subsection{Software Implementado}

O GeNICE primeiramente foi prototipado em linguagem R (R Core Team, 2015), sendo que atualmente está em fase final de desenvolvimento como um plugin em Java ${ }^{3}$ para o Cytoscape (SHANNON et al., 2003).

Ele permite a análise avançada de dados de expressão gênica através de uma interface gráfica intuitiva, incluindo dois outros frameworks: MultiExperiment Viewer (MeV) (HOWE et al., 2011) e o Environment for Developing KDD-Applications Supported by Index-Structures (ELKI) (ACHTERT et al., 2010). O plugin GeNICE é uma evolução do ambiente de seleção de características para análise de expressão gênica DimReduction (LOPES; MARTINS-JR; CESAR-JR, 2008a), Figura 24.

\footnotetext{
${ }^{3}$ Executável disponível em: https://ricardojacomini.github.io
} 


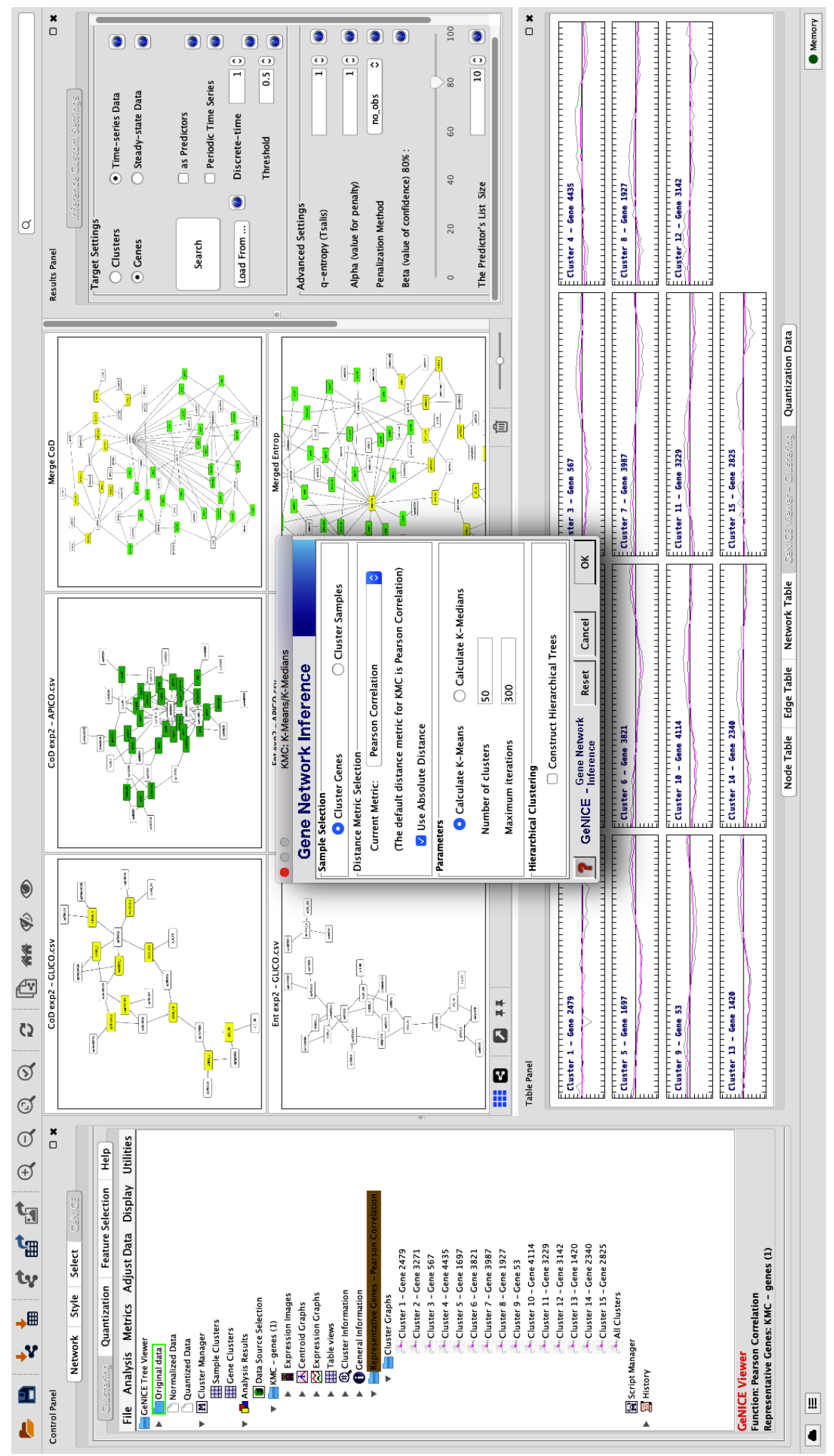

Figura 24. GeNICE: a novel framework for Gene Networks Inference by Clustering, Exhaustive search andmultivariate analysis. 


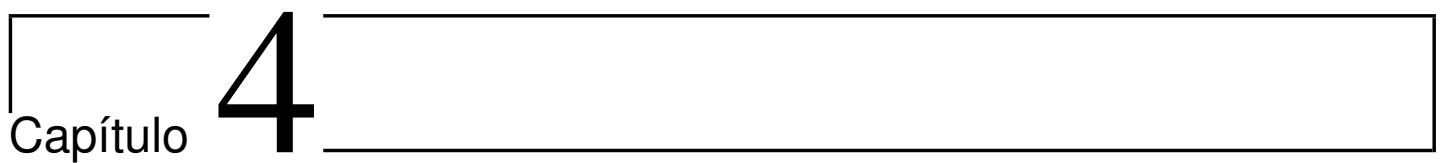

\section{Configuração experimental}

Para avaliar o GeNICE, foram realizados experimentos com dois conjuntos de dados: (A) dados simulados (in silico); e (B) dados reais de microarray. Nesta seção, é descrito o protocolo adotado nos experimentos e o modo de avaliação.

\subsection{Dados Simulados}

\subsubsection{Parametrização}

1. Geração dos dados de entrada: Foi adotado o método in silico SysGenSIM para gerar os dados de expressão gênica (PINNA et al., 2011). Este método segue um modelo de equações diferenciais não-lineares da dinâmica bioquímica de leveduras. Ele é aplicado para gerar os conjuntos de dados para o desafio DREAM5 (MARBACH et al., 2012). Os seguintes parâmetros foram adotados ao gerar os conjuntos de dados: 3 diferentes perfis de expressão foram gerados com 40 amostras cada $(M=40)$. O número de genes varia entre $N \in\{100,1000,5000\}$. O modelo de rede sem escala de Barabási-Albert é adotado para gerar a topologia de rede com grau médio 3 de preditores (BARABÁSI, 2009). O coeficiente de cooperatividade dessa topologia foi ajustado para uma distribuição Gamma com taxa de degradação constante. A variância biológica de transcrição, degradação e ruído foi definida com uma distribuição normal, os demais parâmetros foram ajustados com valores padrão fornecidos pelo simulador. Esses parâmetros devem ser definidos de tal forma que a distribuição dos traços de herdabilidades estimadas sejam próximas daqueles encontrados em dados reais (LIU; FUENTE; HOESCHELE, 2008). 
2. Agrupamento: Na etapa de agrupamento, o algoritmo Lloyd $k$-means (LLOYD, 1982) foi aplicado para agrupar os genes com perfis de expressão similares utilizando os valores iniciais de $k$ de forma determinística, conforme descrito na Seção 3.4. Dois critérios de agrupamento foram adotados: a distância Euclideana e a correlação absoluta de Pearson. O número de grupos foi variado para $k \in\{20,30,40,50\}$ (LIAO, 2005; ACHTERT et al., 2010).

3. Seleção de Características: Foi aplicada uma busca exaustiva nos conjuntos de preditores candidatos de tamanho $p=3$ para todos os $N$ genes considerados alvos, adotando como funções critério o Coeficiente de Determinação (Equação 2.7) e a Entropia Condicional Média (Equação 2.8). É importante lembrar que os preditores candidatos são apenas os genes representantes dos grupos definidos na etapa de agrupamento (um gene para cada um dos $k$ grupos).

4. Análise multivariada: Um subconjunto preditor $\mathbf{Z}$ não é considerado IMP em relação ao alvo $Y$ somente se $I S(\mathbf{Z}, Y)=0$ (neste caso, o método prossegue para a remoção de características redundantes).

5. Construção da PGN: Apenas o melhor subconjunto de preditores para cada gene alvo é considerado para compor a rede e gerar as lógicas de predição.

\subsubsection{Forma de avaliação}

Para avaliar a dinâmica do perfil de expressão de um gene inferido, primeiro a expressão de um gene no tempo $t_{i+1}$ é gerada utilizando a lógica de predição tomando como base os seus preditores no tempo $t_{i}$ obtidos a partir dos dados quantizados como entrada. Isto é realizado considerando todos os genes em todas as amostras temporais, o que leva aos perfis de expressão preditos pela PGN inferida. A Figura 25a fornece uma visão geral deste processo de avaliação, e a Figura 25b mostra mais detalhadamente como obter o perfil de expressão predito a partir da PGN inferida.

Em segundo lugar, um valor de precisão é atribuído a cada gene alvo como a percentagem de pontos de tempo (um para cada amostra no conjunto de dados quantificado) em que o subconjunto preditor foi capaz de definir corretamente o valor de expressão seguinte do gene alvo.

Cada perfil de expressão binário inferido para cada gene é comparado com o seu correspondente perfil de expressão também binário do conjunto de dados quantizados definidos no início do framework, Figura 19c. 


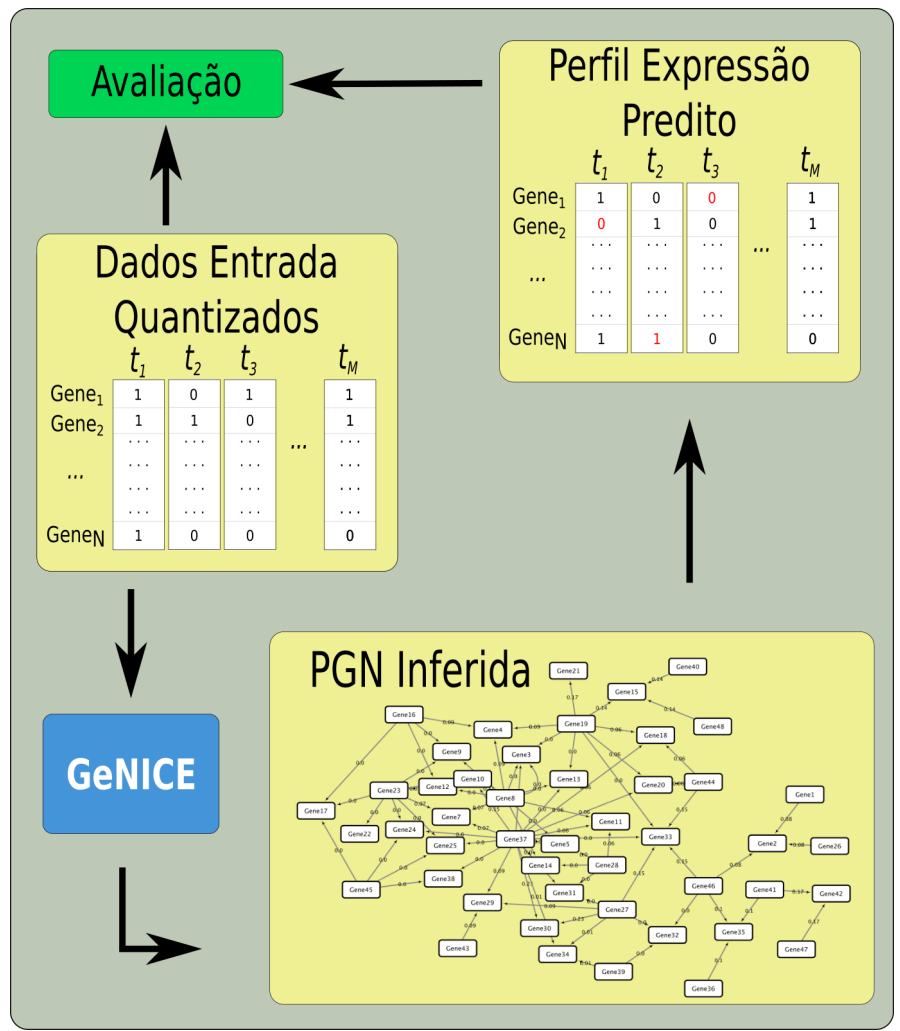

(a)

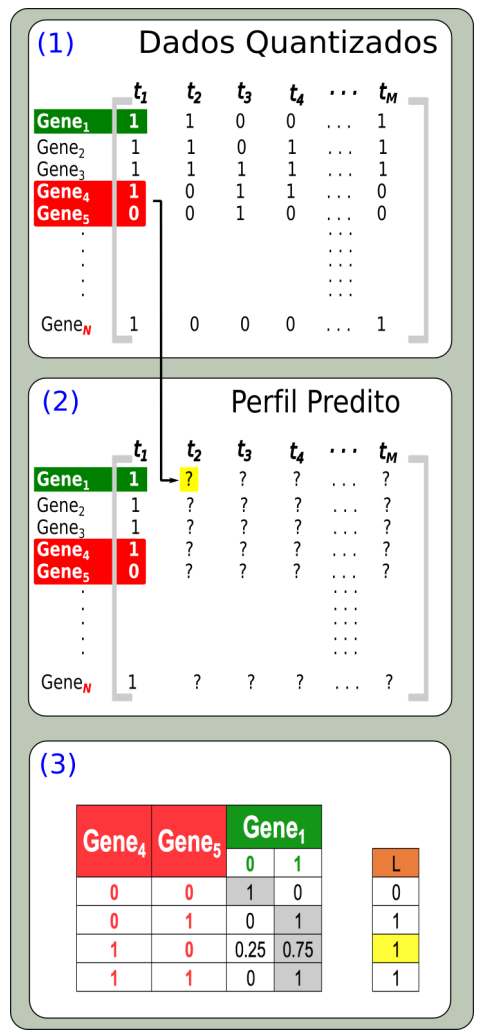

(b)

Figura 25. Avaliação do framework: (a) visão geral do processo de avaliação; (b) alguns detalhes sobre como obter o perfil de expressão predito de um gene $Y$ no tempo $t_{2}$ baseado no melhor subconjunto de preditores $\mathbf{Z}$ no tempo $t_{1}$. O mesmo raciocínio é aplicado a todos os tempos amostrais consecutivos, para todos os genes e seus respectivos preditores.

A porcentagem de amostras corretamente previstas para um determinado gene define sua precisão (é equivalente à distância de Hamming entre dois perfis binários divididos pelo número de amostras temporais presentes no conjunto de dados). A média das precisões de todos os genes alvo é tomada como a precisão global do conjunto de dados inferidos (valores entre 0 e 1 , onde 1 significa precisão perfeita e 0,5 é o valor esperado obtido por suposições aleatórias dos valores dos perfis de expressões binários) (QIAN; DOUGHERTY, 2015).

\subsection{Microarrays de Plasmodium falciparum}

Neste experimento, são adotados dados de expressão gênica do transcriptoma do ciclo de desenvolvimento intraeritrocítico (IDC) do Plasmodium falciparum, um agente causador da malária. Esse transcriptoma foi gerado por medições relativas dos níveis de abundância de mRNA a partir de amostras colhidas de uma cepa chamada HB3, que é bem caracterizada e originada de Honduras (BOZDECH et al., 2003). 
O controle de qualidade do conjunto de dados ( $Q C$ dataset) contendo $m=48$ amostras extraídas de hora em hora com $N=5080$ genes é usada neste experimento, correspondendo às 48 horas do ciclo de desenvolvimento intraeritrocítico.

As amostras correspondentes às $23^{a}$ e $29^{a}$ horas foram descartadas devido à má qualidade (portanto, consideramos a amostra 22 como predecessora da amostra 24 e a 28 como antecessora da amostra 30), o que levou a $M=46$ amostras temporais. Este conjunto de dados de expressão contém oligonucleotídeo ${ }^{1}$ (ou oligonucleótido) da via glicolítica, síntese de ribonucleotídios, síntese de desoxirribonucleotídios, mecanismos celulares responsáveis pela replicação de DNA, ciclo TCA, proteassoma, genoma do plastídeo (apicoplasto), invasão de merozoitos, motilidade de miosina e actina, transcritos de early-ring, genes mitocondriais e grupo traducional de organelas (BOZDECH et al., 2003).

Foram adotados genes sementes (genes alvo) a partir de dois módulos funcionais: via glicolítica e genoma do plastídeo (apicoplasto), como feito em (BARRERA et al., 2007) para obter um número mínimo de preditores que interligam todas as sementes em um mesmo módulo.

A lista de sementes, incluindo suas respectivas anotações, é mostrada na Tabela 3. Espera-se que apenas alguns genes preditores por semente sejam suficientes para conectar todas as sementes do mesmo módulo e seus preditores correspondentes formando uma única componente. Além disso, espera-se que os módulos de glicólise e apicoplasto formem componentes separadas ou uma única componente com interseção muito pequena de genes predizendo sementes de ambos os módulos (esses genes seriam pontes conectando os dois módulos). Em resumo, além da avaliação da dinâmica do sinal de expressão, aqui realizamos também a avaliação da estrutura topológica para verificar se a rede final inferida em torno das sementes apresenta alta intramodularidade e pequena intermodularidade, atendendo a uma propriedade importante do modelo topológico de redes do tipo mundo pequeno (STROGATZ, 2001).

Para a etapa de agrupamento, considerando a avaliação da dinâmica dos perfis de expressão, foram considerados $k \in\{20,30,40,50\}$ como feito no experimento in silico. Para a avaliação topológica, consideramos apenas $k \in\{40,50\}$, uma vez que as precisões relativas à avaliação da dinâmica do perfil de expressão foram melhores para ambos $k=40$ e $k=50$ (as precisões para estes dois valores de $k$ foram muito semelhantes, como mostrado no Capítulo 5).

Para a etapa de seleção de características, foi aplicada uma busca exaustiva para subconjuntos preditores de dimensão $p=3$ para cada alvo. Adotamos o $C o D$ e $I M$

\footnotetext{
${ }^{1}$ É um fragmento curto de uma fita simples de DNA.
} 
Tabela 3. Genes sementes da via glicolítica e do apicoplasto foram considerados no experimento envolvendo dados do Plasmodium falciparum.

\begin{tabular}{|c|c|c|c|c|c|}
\hline \multicolumn{3}{|c|}{ Glicolíticas } & \multicolumn{3}{|c|}{ Apicoplastos } \\
\hline ID dos Oligos & ID do ORF ${ }^{2}$ & Anotações manuais & ID dos Oligos & ID do ORF & Anotações manuais \\
\hline i13056_1 & PFI0755c & 6-fosfofrutoquinase, putativo & pclp & Clp & genoma de plastídeo \\
\hline i1689_2 & PFI1105w & fosfoglicerato quinase & plsu & lsw & genoma de plastídeo \\
\hline j2896_1 & PF11_0208 & fosfoglicerato mutase, putativo & porf 129 & ORF129 & genoma de plastídeo \\
\hline j53_48 & PF10_0155 & enolase & porf91 & ORF91 & genoma de plastídeo \\
\hline m11919_1 & PF14_0425 & fructose-bisfosfato aldolase & prpl4 & rpl14 & genoma de plastídeo \\
\hline m48835_1 & PF14_0598 & gliceraldeído-3-fosfato desidrogenase & prpl16 & rpl16 & genoma de plastídeo \\
\hline n132_136 & PF14_0341 & glucose-6-fosfato isomerase & prpl2 & $\mathrm{rpl} 2$ & genoma de plastídeo \\
\hline n132_40 & PF14_0378 & triose-fosfato isomerase & prpl23 & $\mathrm{rpl} 23$ & genoma de plastídeo \\
\hline opff72413 & MAL6P1.189 & hexoquinase & prpl36 & rpl36 & genoma de plastídeo \\
\hline opff72425 & MAL6P1.160 & piruvato quinase, putativo & prpl4 & rpl4 & genoma de plastídeo \\
\hline & & & prpl6 & rpl6 & genoma de plastídeo \\
\hline & & & prps 11 & rps11 & genoma de plastídeo \\
\hline & & & prps 12 & rps12 & genoma de plastídeo \\
\hline & & & prps 17 & rps17 & genoma de plastídeo \\
\hline & & & prps 19 & rps19 & genoma de plastídeo \\
\hline & & & prps3 & rps3 & genoma de plastídeo \\
\hline & & & prps5 & rps5 & genoma de plastídeo \\
\hline & & & prps 7 & rps 7 & genoma de plastídeo \\
\hline & & & prps8 & rps8 & genoma de plastídeo \\
\hline & & & ptrgln & $\operatorname{trgln}$ & genoma de plastídeo \\
\hline & & & ptrgly & trgly & genoma de plastídeo \\
\hline & & & ptrgly2 & trgly2 & genoma de plastídeo \\
\hline & & & ptrphe & trphe & genoma de plastídeo \\
\hline & & & ptrpro & trpro & genoma de plastídeo \\
\hline & & & ptrthr & trthr & genoma de plastídeo \\
\hline & & & ptrtrp & $\operatorname{trtrp}$ & genoma de plastídeo \\
\hline & & & ptufa & tufa & genoma de plastídeo \\
\hline
\end{tabular}

como funções critério (Equações 2.7 e 2.8).

Para a análise multivariada, foi adotado $I S(\mathbf{Z}, Y)=0$ (Equação 2.6) como critério para eliminar características redundantes, assim como foi feito para o experimento in silico.

Finalmente, para a construção da rede, foi considerado o melhor subconjunto de preditores por gene semente ao realizar a análise da dinâmica do perfil de expressão e a análise da estrutura topológica em torno das sementes de glicólise e de apicoplasto.

\subsection{Hardware e software envolvidos nos experimentos}

O software aplicado nos experimentos de inferência de PGNs foi desenvolvido como um plugin para o Cytos cape, como brevemente descrito na Seção 3.9. Os experimentos foram executadas em um computador Intel ${ }^{\circledR}$ Xeon ${ }^{\circledR} \operatorname{com} 8$ cores CPU E7$28702.40 \mathrm{GHz}$ com $32 \mathrm{~GB}$ de RAM, sob o sistema operacional GNU/Linux Ubuntu de 64 bits. 


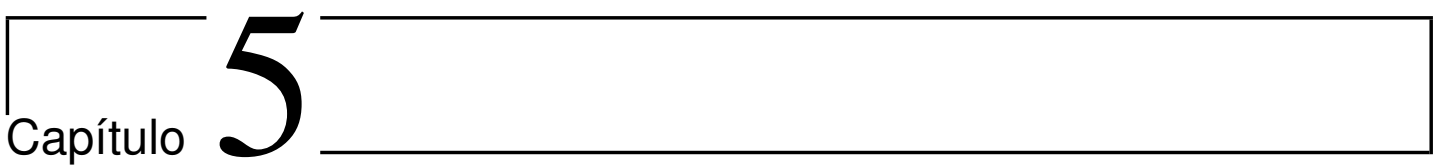

\section{Resultados experimentais e discussão}

Neste capítulo, apresentamos os resultados obtidos para a inferência das Redes

Gênicas Probabilísticas (PGN) nos experimentos descritos no Capítulo 4 aplicando o framework proposto (GeNICE) utilizando dados de expressão simulados (in silico) e reais de microarrays de Plasmodium falciparum.

\subsection{Dados de expressão simulados}

Aqui comparamos as precisões e os tempos de execução da inferência da PGN obtidos pelo GeNICE e pela abordagem original por busca exaustiva pura sem etapas de agrupamento e análise multivariada. Para facilitar a exposição, chamaremos essa segunda abordagem, a original, de Busca Exaustiva Pura daqui para frente.

\subsubsection{Comparação entre o GeNICE e Busca Exaustiva Pura}

A Busca Exaustiva Pura foi realizada apenas para conjuntos de dados compostos por $N=100$ genes, uma vez que este método requer um esforço computacional proibitivo para $N>100$ (vide análise de complexidade computacional descrito na Seção 3.8). Em contraste, avaliamos o desempenho de nossa proposta para $k \in\{20,30,40,50,100\}$, sendo $k$ o número de agrupamentos, e consideramos conjuntos de dados compostos por $N \in\{100,1000\}$ genes.

Neste experimento em particular, os resultados são mostrados apenas para a distância Euclidiana como função critério de agrupamento, uma vez que os resultados para correlação absoluta de Pearson foram semelhantes. A Figura 26 mostra a precisão global dos perfis de expressão inferidos tomando o conjunto de dados quantizado 
como padrão de referência (groundtruth) para diferentes números de agrupamentos, envolvendo a comparação entre o framework proposto e a busca exaustiva pura com $N=100$.

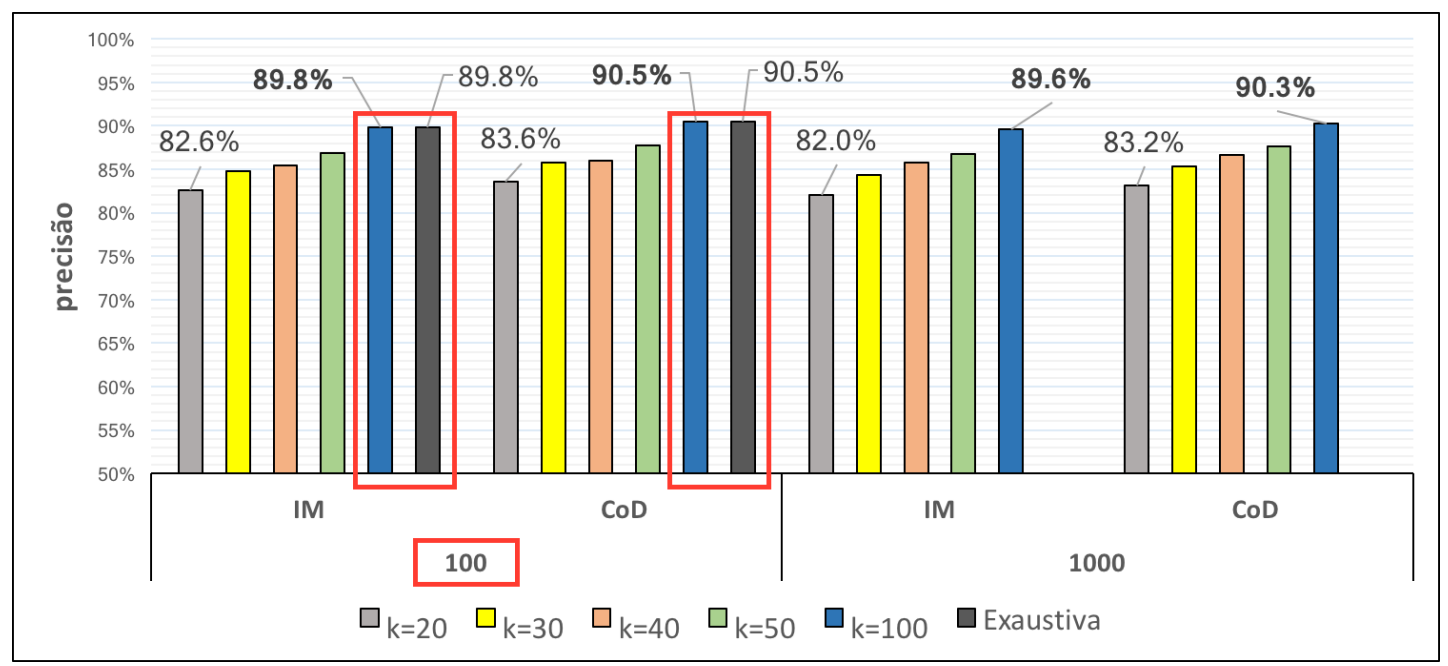

Figura 26. Precisão global do framework proposto para $k \in\{20,30,40,50,100\}$ e $N \in$ $\{100,1000\}$, quando comparada à busca exaustiva pura para $N=100$ apenas (barras pretas legendadas como "Exaustiva"referem-se à busca exaustiva pura). O retângulo vermelho destaca a busca exaustiva e agrupamento para $N$ e $k=100$.

Os tempos de execução correspondentes decorridos para obter os melhores subconjuntos de preditores para um único alvo são mostrados na Tabela 4. Para a busca exaustiva, o tempo decorrido para $N=1000$ foi estimado, uma vez que não foi executado até a conclusão.

Tabela 4. Tempo de processamento (minutos) para a Informação Mútua (IM) e Coeficiente de Determinação $(\mathrm{CoD})$ como funções critério, considerando um gene alvo.

\begin{tabular}{|c|c|c|c|c|c|c|c|c|c|c|c|}
\hline \multicolumn{9}{|c|}{ N $=\mathbf{1 0 0}$ Genes } & \multicolumn{4}{c|}{ = 1000 Genes } \\
\hline & $\boldsymbol{k}=\mathbf{2 0}$ & $\boldsymbol{k}=\mathbf{3 0}$ & $\boldsymbol{k}=\mathbf{4 0}$ & $\boldsymbol{k}=\mathbf{5 0}$ & Exaus. & $\boldsymbol{k}=\mathbf{2 0}$ & $\boldsymbol{k}=\mathbf{3 0}$ & $\boldsymbol{k}=\mathbf{4 0}$ & $\boldsymbol{k}=\mathbf{5 0}$ & $\boldsymbol{k}=\mathbf{1 0 0}$ & Exaus. \\
\hline $\mathrm{IM}$ & $<1$ & $\approx 1$ & $\approx 3$ & $\approx 6$ & $\approx 29$ & $<1$ & $\approx 1$ & $\approx 3$ & $\approx 6$ & $\approx 29$ & $* 20 d$ \\
\hline $\mathrm{CoD}$ & $<1$ & $\approx 1$ & $\approx 2$ & $\approx 5$ & $\approx 28$ & $<1$ & $\approx 1$ & $\approx 2$ & $\approx 5$ & $\approx 28$ & $* 20 d$ \\
\hline
\end{tabular}

Vale ressaltar que a perda de precisão foi muito pequena ao usar nossa proposta, especialmente para $k=50$ (para $N=100$ e $k=100$ é equivalente a busca exaustiva, uma vez que não houve agrupamento envolvido neste caso em particular), enquanto o tempo de processamento foi substancialmente reduzido quando comparado com a busca exaustiva pura. Nossa proposta gastou menos de 30 minutos para processar um gene alvo em todos os casos, independentemente do número de genes $(N)$, o que significa que o framework proposto é escalável em termos de número de genes. Como previsto pela análise de complexidade (Section 3.8), em nossa proposta o tempo de execução é afetado apenas pelo número de agrupamentos $(k)$ para processar um gene 
alvo, enquanto o overhead introduzido pelas etapas de agrupamento e análise multivariada é desprezível.

Neste experimento, a busca exaustiva pura, por sua vez, é inviável para em número da ordem de $N=1000$ genes. De acordo com nossas estimativas, se ela fosse totalmente processada para um único gene alvo considerando $N=1000$ genes, gastaria cerca de 28.800 minutos (20 dias), o que é aproximadamente 1000 vezes maior do que o tempo de processamento requerido pelo framework proposto considerando $N=1000$ e $k=100$. Por fim, também é digno de nota que as precisões de nosso framework para $N=1000$ e $k=100$ foram quase idênticas às da busca exaustiva pura para $N=100$, mesmo que tenha sido aplicado a uma rede que foi 10 vezes maior em termos do número de genes do que o considerado para a busca exaustiva pura. Esta observação é notável porque os conjuntos de dados de expressão reais geralmente apresentam dimensionalidade na ordem de milhares, o que significa que nossa proposta tem potencial de utilidade em outros domínios onde a busca exaustiva pura também seria inviável.

Em relação ao impacto da função critério nas precisões de predição obtidas nesses experimentos, o CoD e a Informação Mútua implicaram em precisões muito próximas para todos os valores considerados de $N$ e $k$.

\subsubsection{Avaliação da precisão dos perfis de expressão dos genes}

Com a finalidade de avaliar a precisão de predição da dinâmica para cada perfil de expressão gênica, variou-se os valores de $k(k \in\{20,30,40,50\})$ para uma rede com 5000 genes $(N=5000)$. A Figura 27 mostra uma distribuição boxplot de 5000 predições (uma para cada gene como alvo) para toda tripla $(k, \mathcal{J}, c)$, onde $\mathcal{J}$ representa as funções critério de seleção de características: informação mútua e $\mathrm{CoD}$, e $c$ representa os critérios de agrupamento: correlação absoluta de Pearson e distância Euclideana. Observamos que há uma linha de tendência crescente geral de precisão para os valores de $k$, como esperado. Por outro lado, o critério de agrupamento não demonstrou um impacto significativo nos resultados. Com relação à escolha do critério de seleção de características, o CoD obteve consistentemente melhores resultados de precisão do que a informação mútua. 


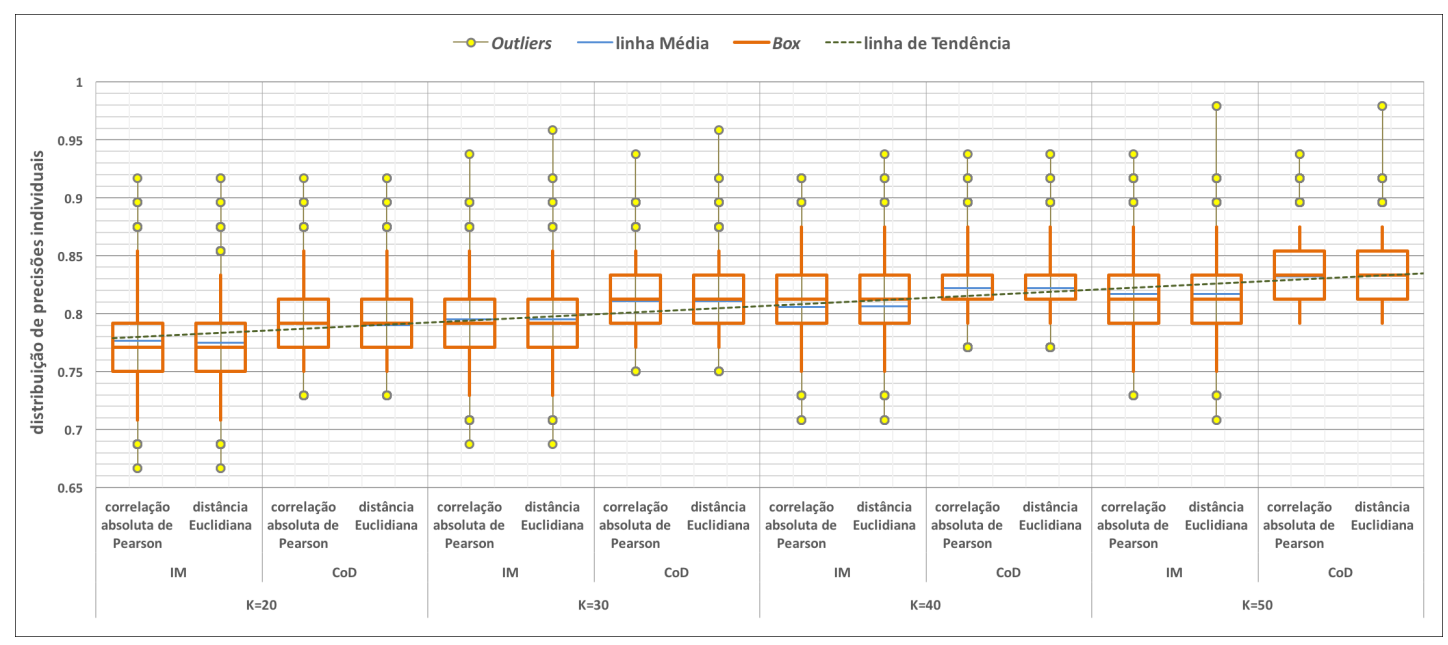

Figura 27. Distribuição (boxplot) de precisões dos perfis de expressão dos genes para cada tripla $(k, \mathcal{J}, c)$ e dados simulados in silico gerados com $N=5000$ genes. $k \in\{20,30,40,50\}$; $\mathcal{J} \in\{$ Informação Mútua (IM), CoD $\} ; c \in\{$ correlação absoluta de Pearson, distância Euclideana . A linha tracejada na cor preta representa a linha de tendência que melhor se ajusta às distribuições.

\subsection{Microarrays de Plasmodium falciparum}

\subsubsection{Avaliação da precisão de predição dos perfis de expressão dos genes}

Como feito para os dados simulados in silico, aqui o objetivo é avaliar a precisão da predição da dinâmica para cada perfil de expressão gênica variando os valores para $k \in\{20,30,40,50\}$. A Figura 28 mostra uma distribuição de 5080 predições (uma para cada gene) para toda tripla $(k, \mathcal{J}, c)$, em que $\mathcal{J}$ representa as funções critério de seleção de características: informação mútua e $\mathrm{CoD}$, e $c$ representa os critérios de agrupamento: correlação absoluta de Pearson e distância Euclidiana.

Observamos que as precisões alcançadas para todos os valores de $k$ são muito melhores do que as precisões para o experimento equivalente para dados simulados (compare as Figuras 27 e 28). Para $k=20$ (pior cenário), a precisão média foi de $95 \%$ contra $78 \%$ para o experimento com dados simulados. Para todo $k \geq 30$, as precisões médias obtidas foram cerca de $97 \%$ contra $83 \%$ para o melhor cenário em relação ao experimento com dados simulados $(k=50)$. De fato, o desempenho da proposta aplicada em dados de microarray de Plasmodium falciparaum foram notáveis, uma vez que pelo menos $25 \%$ dos perfis de expressão foram perfeitamente preditos para $k \geq 30$ (todos os terceiros quartis atingiram 100\% de precisão). Quanto à escolha da função critério e do critério de agrupamento, o impacto na precisão foi negligível de forma geral. 


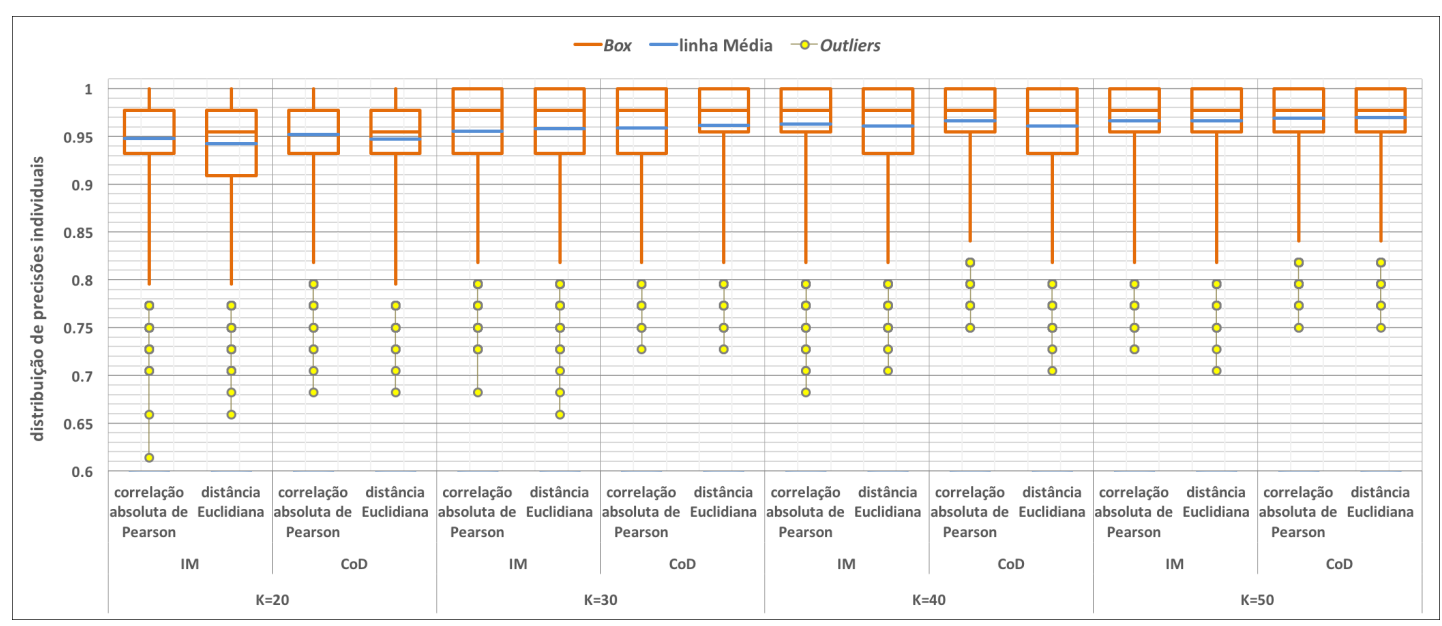

Figura 28. Distribuição (boxplot) de precisões dos perfis de expressão dos genes para cada tripla $(k, \mathcal{J}, c)$ e dados reais de Plasmodium falciparum contendo 5080 genes $(N=5080)$. $k \in\{20,30,40,50\} ; \mathcal{J} \in\{$ Informação Mútua (IM), CoD $\} ; c \in\{$ correlação absoluta de Pearson, distância Euclideana\}.

\subsubsection{Avaliação topológica envolvendo dados reais}

A presente seção avalia se a PGN inferida para 37 genes sementes (10 genes da via glicolítica e 27 genes de apicoplasto) utilizadas como alvos produz uma topologia com grandes proporção de conexões intramodulares e pequena proporção de conexões intermodulares, uma das principais propriedades de redes do tipo mundo pequeno observadas por (STROGATZ, 2001).

A Tabela 5 apresenta as características das redes inferidas para $k \in\{40,50\}, \mathcal{J} \in$ \{CoD, Informação Mútua\} e $c \in\{$ correlação absoluta de Pearson, distância Euclideana\}, incluindo número de nós, arestas e pontes ${ }^{1}$, ou seja, número de preditores de alvos de diferentes módulos biológicos (sementes glicolíticas e de apicoplastos).

A rede com o menor número de pontes foi para o agrupamento com $k=50$ grupos, correlaçãa absoluta de Pearson e CoD: apenas três genes. A rede correspondente é apresentada na Figura 29. Vale ressaltar que cada módulo apresenta forte conectividade entre seus elementos: o módulo de glicólise apresenta 14 preditores que não são sementes, enquanto o apicoplasto apresenta 17 preditores que não são sementes. Além disso, algumas sementes de apicoplasto predizem umas às outras (interações entre nós verdes). Outra observação importante é que existem hubs de módulo (preditores que se conectam a um grande número de sementes em comparação com a média), como o gene f10044_2 em relação ao módulo do apicoplasto e 12_279 em relação ao módulo de glicólise. Esses três fatos combinados (pequeno número de preditores conectados a sementes de ambos os módulos, grande número de preditores dentro de cada módulo e

\footnotetext{
${ }^{1}$ Genes que fazem interseções entre a via glicolítica e apicoplasto.
} 
Tabela 5. Quantidades de nós e de arestas para as redes com o melhor subconjunto preditor para cada uma das 10 sementes glicolíticas e 27 sementes de apicoplastos e as correspondentes intersecções (número de preditores que predizem sementes de ambos os módulos).

\begin{tabular}{|c|c|c|c|c|c|c|c|c|c|}
\hline & \multicolumn{4}{|c|}{ CoD } & \multicolumn{4}{|c|}{ IM } \\
\hline & & & & & $\mathrm{k}=$ & & & & \\
\hline & & \multicolumn{2}{|c|}{ absoluta de Pearson } & \multicolumn{2}{|c|}{ Euclidiana } & \multicolumn{2}{|c|}{ absoluta de Pearson } & \multicolumn{2}{|c|}{ Euclidiana } \\
\hline & sementes & nós & arestas & nós & arestas & nós & arestas & nós & arestas \\
\hline Glicolítica & 10 & 24 & 30 & 27 & 30 & 25 & 30 & 27 & 30 \\
\hline Apicoplasto & 27 & 46 & 81 & 43 & 97 & 49 & 98 & 44 & 104 \\
\hline \multicolumn{2}{|l|}{ Ponte } & \multicolumn{2}{|r|}{6} & \multicolumn{2}{|r|}{5} & \multicolumn{2}{|r|}{5} & \multicolumn{2}{|r|}{9} \\
\hline
\end{tabular}

\begin{tabular}{|c|c|c|c|c|c|c|c|c|c|}
\hline & \multicolumn{4}{|c|}{ CoD } & \multicolumn{4}{|c|}{ IM } \\
\hline & & \multicolumn{8}{|c|}{$k=50$} \\
\hline & & \multicolumn{2}{|c|}{ absoluta de Pearson } & \multicolumn{2}{|c|}{ Euclidiana } & \multicolumn{2}{|c|}{ absoluta de Pearson } & \multicolumn{2}{|c|}{ Euclidiana } \\
\hline & sementes & nós & arestas & nós & arestas & nós & arestas & nós & arestas \\
\hline Glicolítica & 10 & 24 & 30 & 26 & 30 & 25 & 30 & 26 & 30 \\
\hline Apicoplasto & 27 & 44 & 104 & 44 & 81 & 47 & 81 & 46 & 81 \\
\hline \multicolumn{2}{|l|}{ Ponte } & \multicolumn{2}{|r|}{3} & \multicolumn{2}{|r|}{7} & \multicolumn{2}{|r|}{6} & \multicolumn{2}{|r|}{6} \\
\hline
\end{tabular}

alguns hubs de módulos) sugerem que esta rede apresenta propriedades de rede mundo pequeno e livre de escala, corroborando outros estudos de redes biológicas (STROGATZ, 2001; BARABÁSI; OLTVAI, 2004).

Além disso, apenas 3 ou menos preditores por semente foram suficientes para conectar cada módulo. Em comparação, (BARRERA et al., 2007) (abordagem de inferência PGN original, que não inclui as etapas de agrupamento e análise multivariada) necessitava de 10 melhores preditores individuais ou 5 melhores pares de preditores (10 no total) por semente para conectar as sementes glicolíticas em um única componente conexa, enquanto 6 melhores preditores individuais ou 3 melhores pares ( 6 no total) por semente foram necessárias para conectar as sementes de apicoplasto. Isso mostra que a abordagem da inferência de PGNs combinada com agrupamento e análise multivariada são mais promissoras na captura das modularidades das redes biológicas existentes.

O experimento foi repetido para $k=100$ e correlação absoluta de Pearson como critério de agrupamento, tanto usando a informação mútua como o $\mathrm{CoD}$ como função critério de seleção de características. As PGNs inferidas para a informação mútua e o CoD são apresentadas nas Figuras 30 e 31, respectivamente. A sumarização dessas redes com o número de genes e de arestas em cada módulo funcional e o número de genes fazendo a ponte entre os módulos (interseção) é apresentada na Tabela 6. Além delas possuírem características topológicas parecidas como alta conectividade intramódulo e alguns poucos genes formando uma ponte entre módulos, é interessante observar que surgiu um $h u b$ de saída ainda mais proeminente do que a rede obtida para $k=50$ apresentada na Figura 29: o gene opfg0008 possui graus de saída 19 e 22 para 


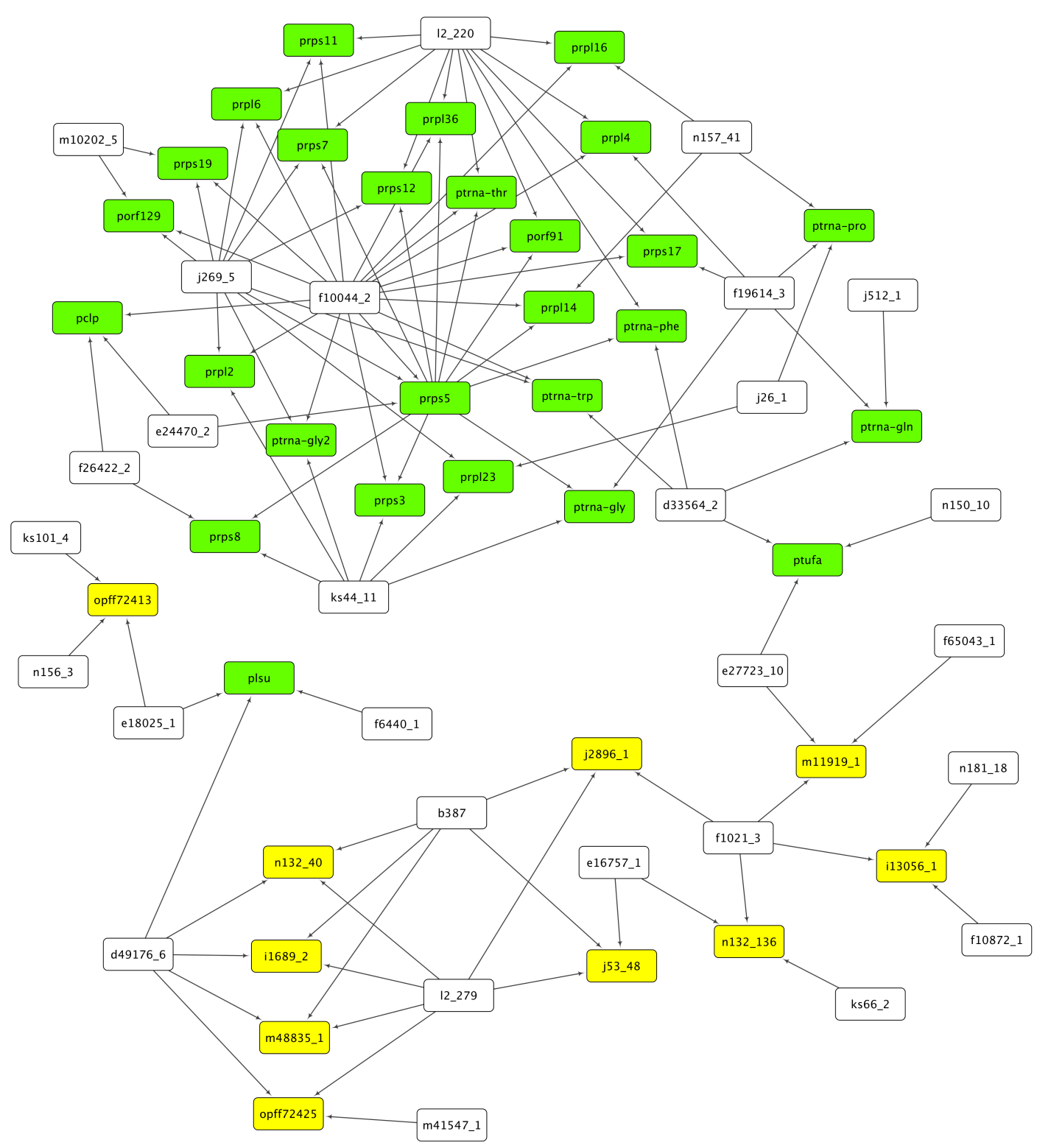

Figura 29. PGN inferida para as sementes glicolíticas (nós amarelos) e apicoplastos (nós verdes) para $k=50$, correlação absoluta de Pearson e CoD. Os nós brancos indicam genes preditores que não são sementes. Visualização gerada no Cytoscape (SHANNON et al., 2003).

as redes obtidas por informação mútua e $\mathrm{CoD}$, respectivamente, além de realizar uma ponte de ligação entre sementes de glicólise e de apicoplasto. A interseção entre as listas dos preditores que apareceram nessas redes resultou em 32 genes, enquanto a união dessas mesmas listas resultou em 45 genes. Assim, o coeficiente de similaridade de Jaccard definido pela razão do número de elementos da interseção pelo número de elementos da união dessas listas foi igual a $32 / 45=0,71$, o que mostra que as listas de genes dessas redes possuíram boa similaridade.

Para checar se as redes apresentadas nas Figuras 29, 30 e 31 tendem a apresentar 
Tabela 6. Números de nós e de arestas para as redes com o melhor subconjunto de preditores para cada uma das 10 sementes glicolíticas e 27 sementes de apicoplasto e as correspondentes intersecções (número de preditores de sementes de ambos os módulos) para a correlação absoluta de Pearson como função critério, para as duas funções critério (CoD e Informação Mútua), e número de agrupamentos $k=100$.

\begin{tabular}{|c|c|c|c|c|c|}
\hline & \multicolumn{2}{|c|}{ CoD } & \multicolumn{2}{|c|}{ IM } \\
\hline & sementes & nós & arestas & nós & arestas \\
\hline Glicolítica & 10 & 26 & 30 & 28 & 30 \\
\hline Apicoplasto & 27 & 49 & 83 & 52 & 82 \\
\hline Ponte & & & 4 & & 3 \\
\hline
\end{tabular}

características de topologia livre de escala, a Figura 32 apresenta as distribuições de grau de saída para essas três redes, bem como essas mesmas distribuições na escala $\log$-log. Observa-se que as três redes possuem uma tendência de formar uma cauda longa em suas distribuições de grau. Essa tendência é confirmada pelos respectivos gráficos na escala log-log, para os quais os coeficientes de determinação $\left(R^{2}\right)$ foram de $0,610,0,789$ e 0,762 , considerados moderadamente altos.

Finalmente, os sinais de expressão gênica para cada um dos $k=50$ agrupamentos gerados usando a distância Euclideana e a correlação absoluta de Pearson para os dados reais estão ilustrados na Figura 33. Observa-se-se que a maioria dos agrupamentos apresentam perfis de expressão com uma forma de onda senoidal bastante destacada, o que corrobora o estudo de Bozdech et al. (2003) que revelou que os dados de expressão de Plasmodium falciparum apresentam uma proporção bastante grande de genes (pelo menos 50\%) com perfis fortemente senoidais. Este é um indicativo de que as decisões tomadas na etapa de agrupamento estão levando a grupos (clusters/módulos) biologicamente significativos, com impacto benéfico para as próximos etapas da inferência de PGNs. 


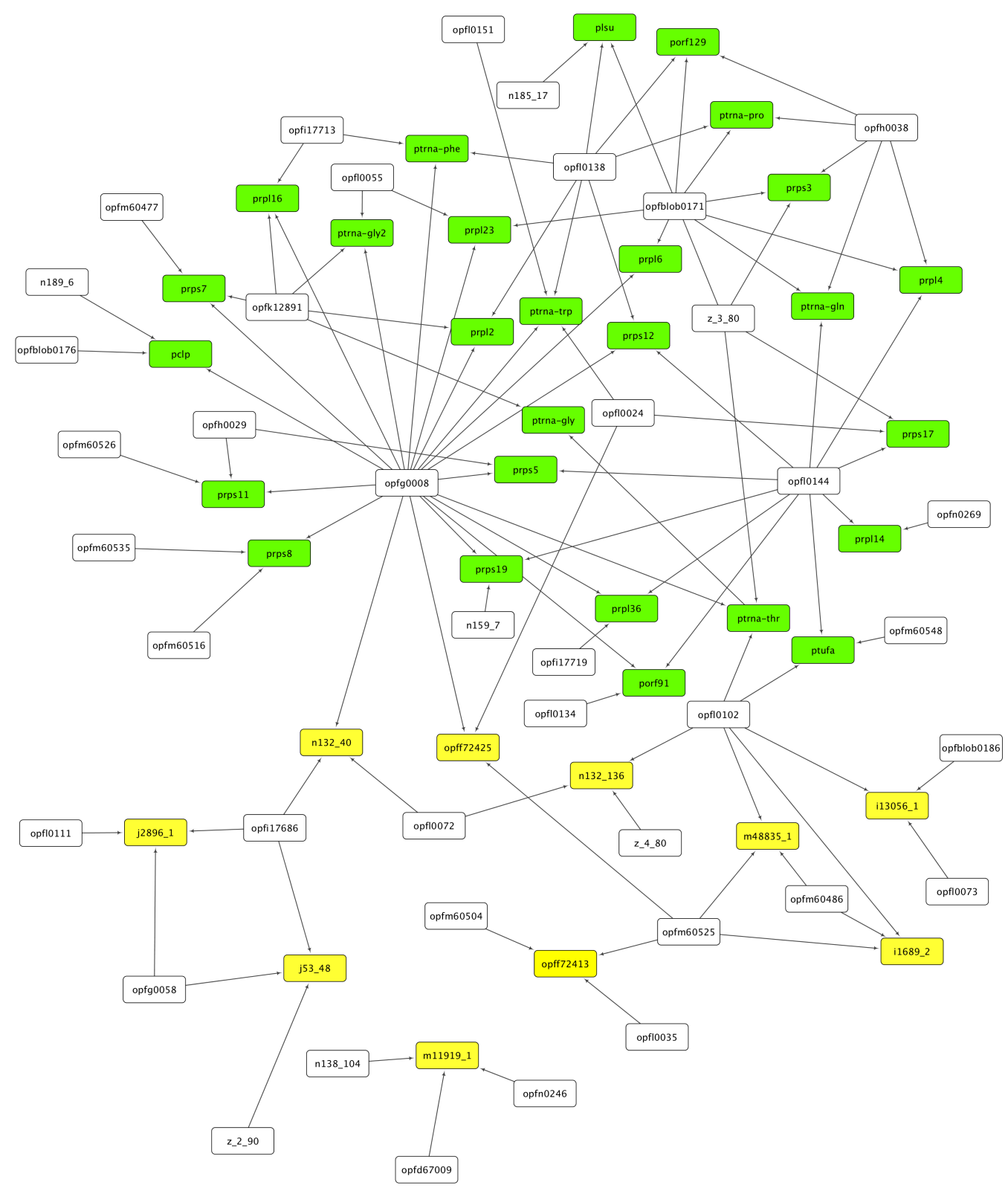

Figura 30. PGN inferida para as sementes glicolíticas (nós amarelos) e apicoplastos (nós verdes), usando correlação absoluta de Pearson como critério de agrupamento, informação mútua como função critério para seleção de características, e 100 agrupamentos $(k=100)$. Os nós brancos indicam genes preditores que não são sementes. Visualização de rede gerada no Cytoscape (SHANNON et al., 2003). 


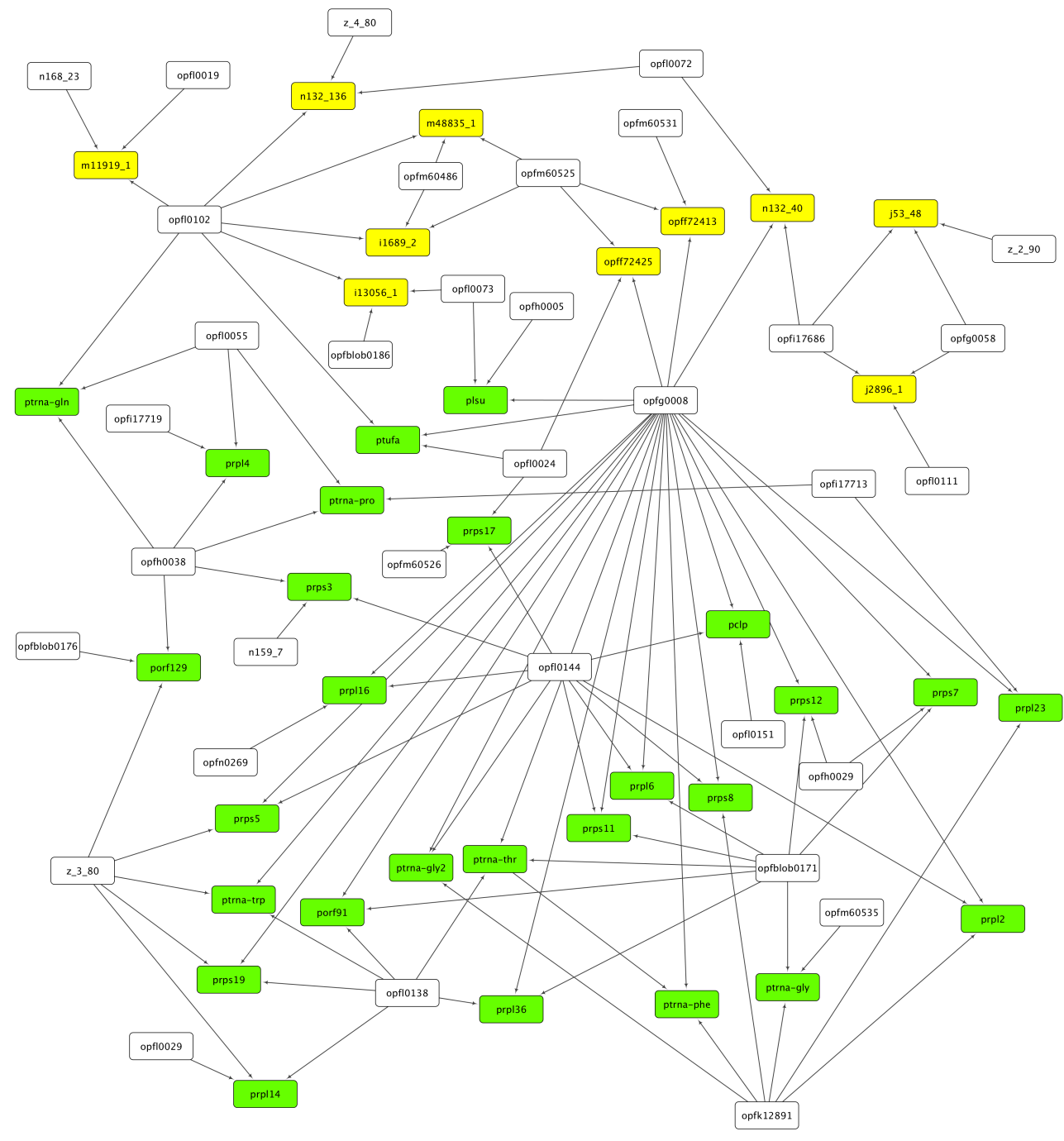

Figura 31. PGN inferida para as sementes glicolíticas (nós amarelos) e apicoplastos (nós verdes), usando correlação absoluta de Pearson como critério de agrupamento e $\mathrm{CoD}$ como função critério para seleção de características, e 100 agrupamentos $(k=100)$. Os nós brancos indicam genes preditores que não são sementes. Visualização de rede gerada no Cytoscape (SHANNON et al., 2003). 


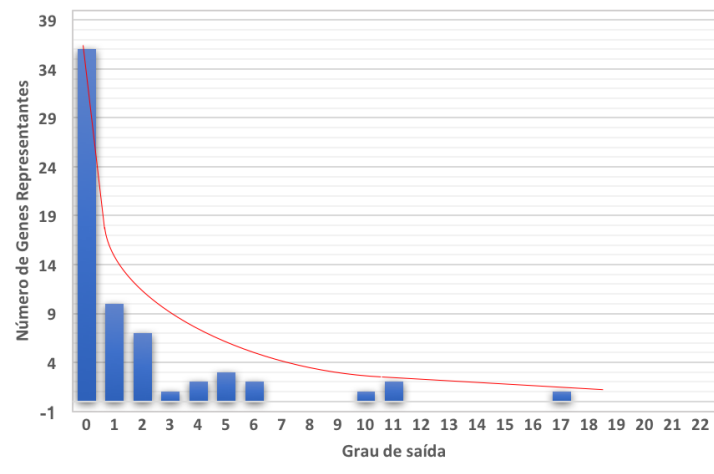

(a)

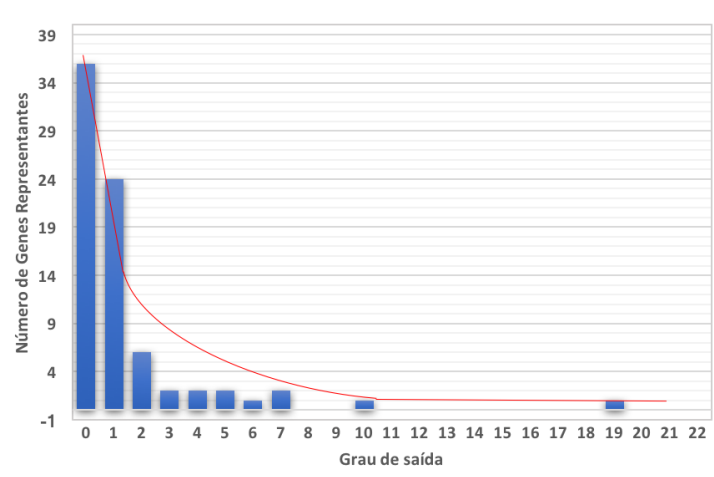

(c)

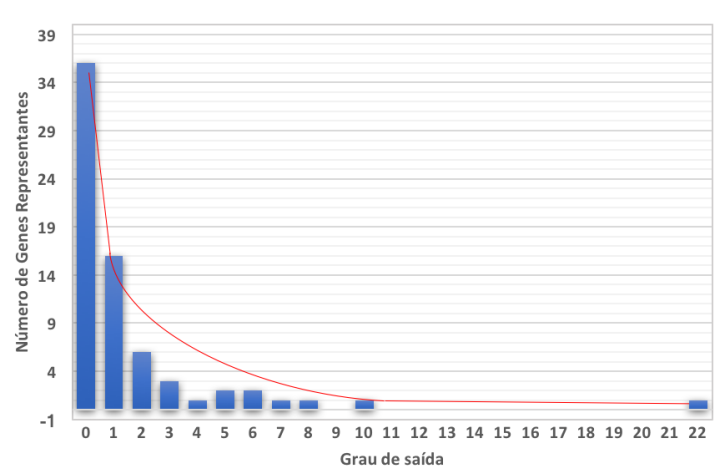

(e)

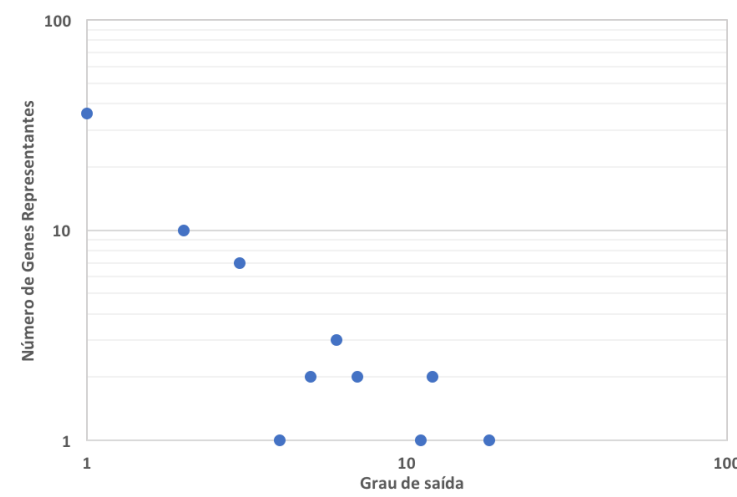

(b)

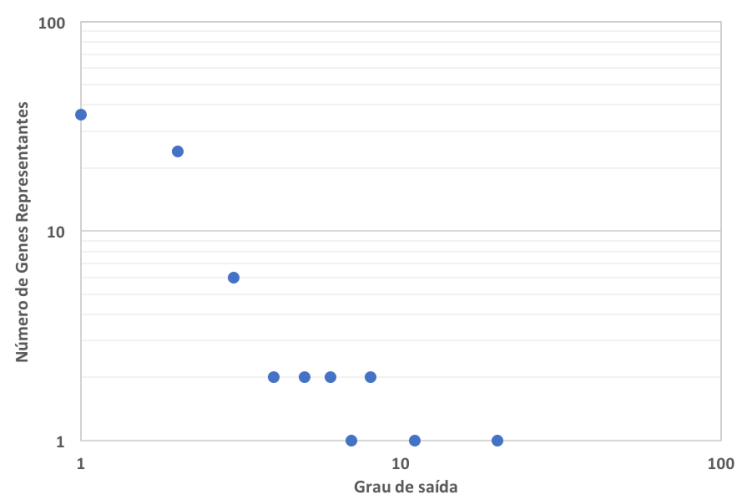

(d)

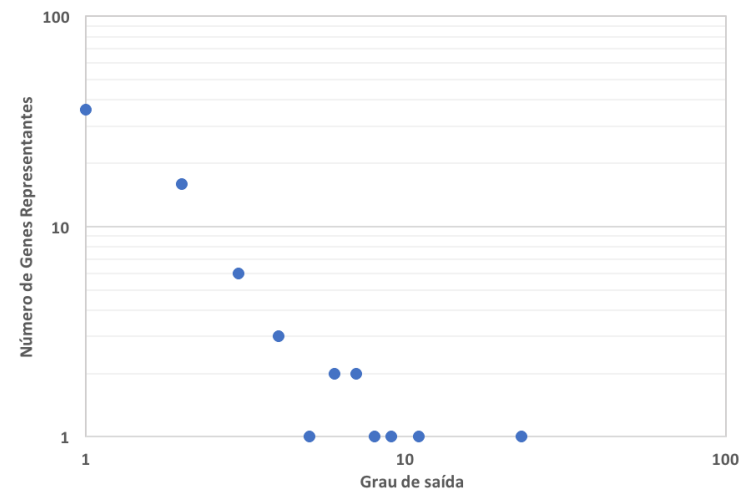

(f)

Figura 32. Distribuições de graus na escala normal para as redes apresentadas nas Figuras 29 (painel a), 30 (painel c) e 31 (painel e). Nos painéis (b) (d) e (f) seus respectivos gráficos na escala log-log. 


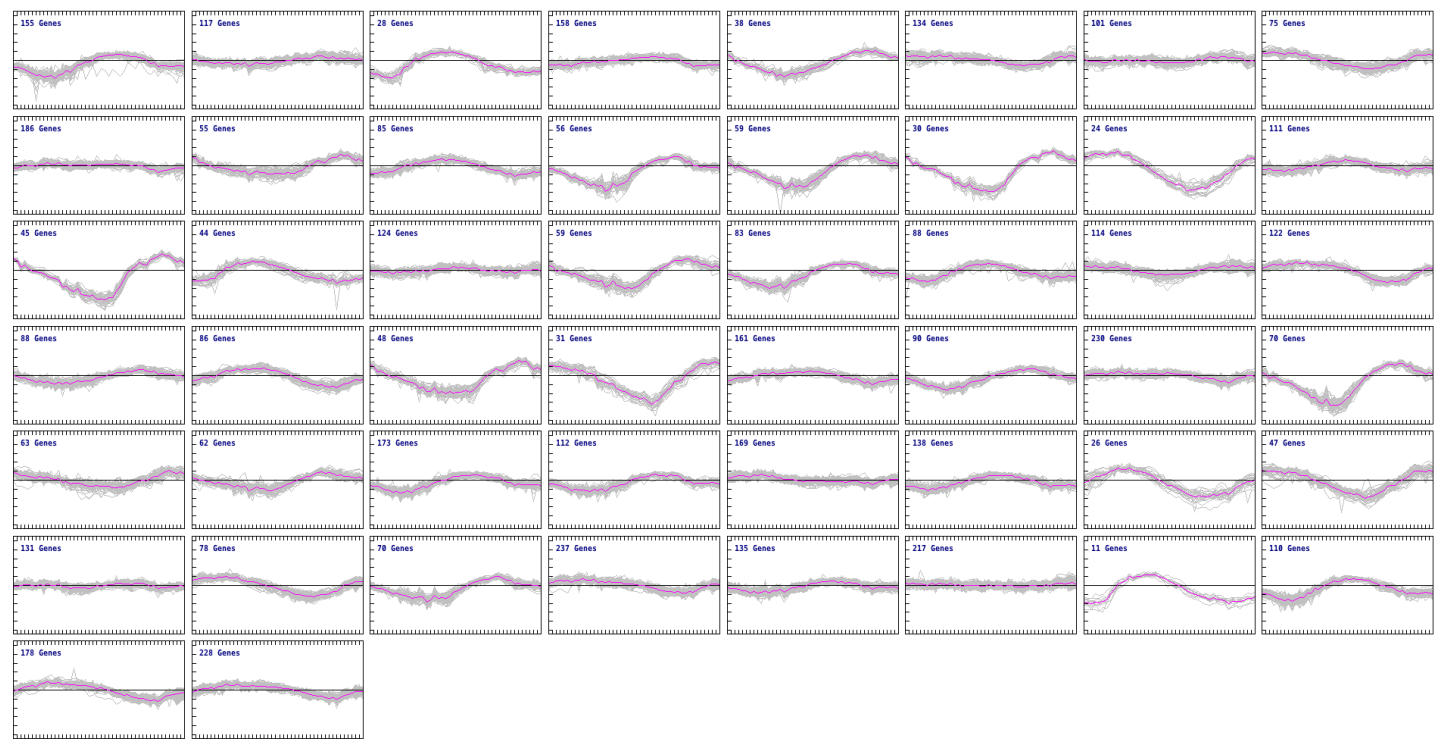

(a)

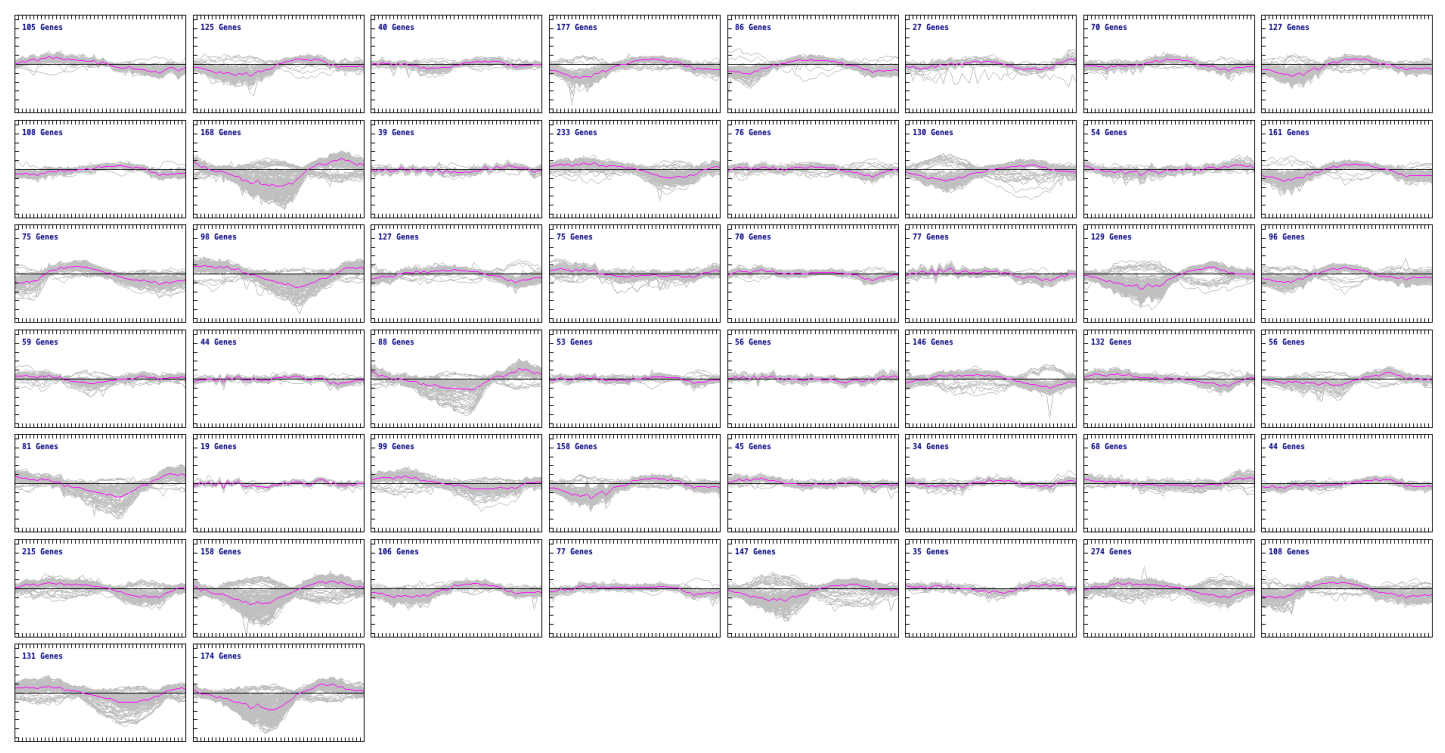

(b)

Figura 33. Sinais de expressão dos genes presentes em cada um dos $k=50$ agrupamentos baseados no conjunto de dados do Plasmodium falciparum: (a) distância Euclideana; (b) correlação absoluta de Pearson. Os sinais na cor rosa representam os respectivos sinais de expressão dos genes representantes. 
Capítulo 1

\section{Conclusão}

Nesta tese foi proposto o GeNICE, um arcabouço para a inferência de redes de regulação gênica em que a principal novidade consiste na aplicação de um método de agrupamento para reduzir a complexidade da busca pelos melhores subconjuntos de preditores por gene alvo, considerando o modelo das redes gênicas probabilísticas (PGN). A aplicabilidade dessa proposta foi demonstrada em experimentos utilizando dados de expressão gênica sintéticos e reais de microarrays de Plasmodium falciparum, para os quais foi capaz de preservar a precisão da predição de perfis de expressão gênica obtida pela busca exaustiva pura, enquanto reduz substancialmente a complexidade computacional da busca dos melhores preditores por seleção de características.

Em relação aos conjuntos de dados sintéticos envolvidos nos experimentos, eles foram gerados por um modelo complexo e detalhado (equações diferenciais não-lineares baseadas na dinâmica bioquímica de leveduras (PINNA et al., 2011)), enquanto o modelo PGN em que nosso arcabouço se baseia é muito mais simples. Mesmo supondo um modelo mais simples, nossa proposta descreveu os perfis de expressão sintéticos com grande precisão (cerca de 90\%) considerando conjuntos de dados com 1000 genes. Por outro lado, para redes muito maiores (5000 genes) as precisões foram menores. Este fato pode estar relacionado à escolha de parâmetros para gerar os dados simulados, especialmente no que se refere ao ruído. Além disso, o modelo PGN assume suposições fortes de simplificação para lidar com as limitações impostas pelos dados que podem não ser adequadas para modelos complexos. No entanto, estudos adicionais precisam ser realizados para confirmar estas hipóteses.

Ao considerar a precisão da predição do sinal de expressão gênica do Plasmodium falciparum como dados de entrada, os resultados foram notavelmente superiores aos obtidos pelos experimentos com dados simulados, atingindo cerca de $97 \%$ em média 
para um número de agrupamentos tão pequeno (apenas 30). Além disso, a avaliação da estrutura topológica envolvendo sementes glicolíticas e de apicoplastos apresentou grande modularidade conectando sementes da mesma função e uma pequena interconexão entre as sub-redes correspondentes às duas funções acima mencionadas. Isto foi conseguido com o melhor subgrupo de genes preditores por semente (no máximo três genes preditores). Os genes hubs foram observados em ambos os módulos. Tais observações são significativas do ponto de vista biológico, uma vez que até mesmo uma pequena rede inferida foi capaz de exibir características de redes complexas que normalmente estão presentes em redes biológicas, como propriedades de redes mundo pequeno e livres de escala (STROGATZ, 2001; BARABÁSI; OLTVAI, 2004).

Nossa proposta consiste em um arcabouço, onde vários aspectos relativos a diferentes passos envolvidos podem ser melhorados. Por exemplo, outros algoritmos de agrupamento podem ser testados, bem como outras métricas de distância e métodos para definir os genes representantes. Além disso, o algoritmo de agrupamento pode ser aplicado após o passo de quantização, o que pode levar a grupos com menor variabilidade entre os seus respectivos perfis de expressão gênica. Em relação à análise multivariada para remoção de características redundantes, Chen and Braga-Neto (2015) desenvolveram um método estatístico para determinação automática de limiar da pontuação para predição intrinsecamente multivariada, resultando em um p-valor de significância para essa pontuação. A aplicação deste teste estatístico nesta etapa pode levar a estruturas topológicas ainda mais enxutas e efetivas.

Embora a compreensão e a modelagem das propriedades e estruturas dos sistemas biológicos reais ainda sejam um problema em aberto, nossa proposta mostrou-se promissora em auxiliar os profissionais da biomedicina e áreas relacionadas na tomada de decisões sobre o controle da dinâmica dos sistemas reguladores genéticos, além de ser um sistema viável em ambientes com recursos computacionais limitados, o que não é possível considerando trabalhos anteriores que aplicam busca exaustiva pura como forma de garantir o melhor subconjunto preditor para cada alvo.

Vale ressaltar que a regulação dentro de uma espécie é perfeitamente coordenada, onde pequenas diferenças em seu desenvolvimento altera toda a rede, ou seja, modifica toda a cascata de genes que são regulados e mudanças nessas topologias podem explicar essas diferenças. Esse arcabouço pode auxiliar profissionais a estudar e inferir vias metabólicas e conhecer como são suas estruturas e vias a partir das redes inferidas. Alterações nessas vias levam a fenótipos diferentes que podem variar desde doenças até reações a medicamentos, ou seja, intercorrências que podem alterar os dados de expressão gênica, e por consequência a topologia da rede. Recentes estudos em nutrigenômica, demonstram que os alimentos podem alterar a transcrição de um DNA e o 
funcionamento dos genes, deste modo, quanto mais íntegros os genes estiverem, menor será a possibilidade de desenvolver alguma doença (BARAKAT, 2017). De acordo com Barabási, Gulbahce and Loscalzo (2011) os avanços nesse sentido são essenciais para a identificação de novos genes ligados a doenças, para descobrir a importância biológica de mutações associadas a doenças identificadas por estudos de associação genômica e para identificar alvos de fármacos ou biomarcadores para doenças complexas. Desta forma, a implementação deste arcabouço como um plugin para o Cytoscape (SHANNON et al., 2003), cuja primeira versão encontra-se em fase final de desenvolvimento, deverá contribuir para novos estudos mais aprofundados.

Finalmente, nossa proposta mostrou-se escalável, uma vez que fomos capazes de aumentar em 50 vezes o número de genes nos dados de expressão de entrada sem aumento significativo no tempo de processamento de seleção de características de forma exaustiva para um único gene alvo, o que implica que o tempo de processamento aumenta linearmente com o número de genes em toda rede, desde que $p$ e $k$ sejam fixos. Os resultados demonstram que esse arcabouço pode auxiliar nos estudos de modelos biológicos em tempo hábil.

\subsection{Trabalhos futuros}

Dada a natureza interdisciplinar do GeNICE, evoluí-lo para um sistema distribuído de tal modo que possa ser executado em um paradigma de computação orientada a serviços, deverá contribuir para um desenvolvimento de maneira colaborativa e possibilitará uma maior integração dos pesquisadores e instituições na troca de conhecimentos, além de permitir uma maior visibilidade internacional, visando futuras parcerias. Segue abaixo um detalhamento das perspectivas futuras derivadas deste trabalho.

- Estender o GeNICE da sua versão atual standalone, fortemente acoplado, para o paradigma de sistemas distribuídos fazendo uso de computação orientada a serviços, de tal forma que o GeNICE atue como um gateway para inferência de PGNs na nuvem (cloud);

- Desenvolver uma camada de agentes para monitorar cada módulo de serviços atuando como um escalonador de recursos computacionais sob demanda;

- Comparar algoritmos distintos de aprendizado e diferentes medidas para obter o maior ganho de informação para auxiliar na definição de predição intrinsecamente multivariada (IMP); 
- Investigar o conceito IMP ${ }^{1}$ com limiares adaptativos na obtenção de redes regulatórias minimais;

- Investigar o impacto de aplicar o agrupamento sobre os dados quantizados, ao invés dos dados reais normalizados;

- Estudar como o GeNICE poderia ser aplicado para definir mudanças de contexto ao longo dos dados com base na precisão dos dados gerados pelas redes inferidas para diversas partições de intervalos ao longo dos dados, onde cada intervalo resultaria em uma rede inferida específica e um valor de precisão;

- Estudar e integrar dados multi-ómicas através de uma abordagem multicamadas, já que os dados biológicos podem ser de fontes diferentes;

- Integrar dados de expressão com sequências de DNA para avaliar se os agrupamentos com isoformas poderia auxiliar o processo de inferência da PGNs;

- Análise de robustez dos resultados através de escolhas de representantes diferentes para os grupos, ou seja, variar os representantes definidos pelos agrupamentos e avaliar o impacto sobre as redes inferidas, tanto do ponto de vista topológico, como da dinâmica das expressões geradas.

- Colaborar com profissionais da área biológica para validar e entender melhor as funções biológicas das redes fornecidas.

\footnotetext{
${ }^{1}$ Um gene alvo é predito de forma intrinsecamente multivariada pelos seus preditores se nenhum de seus subconjuntos próprios conseguem inferir o comportamento do alvo, mas o conjunto completo dos preditores prevê quase perfeitamente o seu comportamento.
} 


\section{REFERÊNCIAS}

ACHTERT, E.; KRIEGEL, H.-P.; REICHERT, L.; SCHUBERT, E.; WOJDANOWSKI, R.; ZIMEK, A. Visual Evaluation of Outlier Detection Models. In: SPRINGER. International Conference on Database Systems for Advanced Applications. 2010. p. 396-399.

AHUJA, M. Structure of DNA. Manual of Cytogenetics in Reproductive Biology, JP Medical Ltd, p. 1, 2014.

AKUTSU, T.; MIYANO, S.; KUHARA, S. et al. Identification of Genetic Networks from A Small Number of Gene Expression Patterns under The Boolean Network Model. In: Proceedings of the Pacific Symposium on Biocomputing (PSB). [S.1.: s.n.], 1999. v. 4, p. 17-28.

ALBERT, R.; BARABÁSI, A.-L. Statistical Mechanics of Complex Networks. Reviews of Modern Physics, APS, v. 74, n. 1, p. 47, 2002.

ALBERT, R.; OTHMER, H. G. The Topology of The Regulatory Interactions Predicts The Expression Pattern of The Segment Polarity Genes in Drosophila Melanogaster. Journal of Theoretical Biology, v. 223, n. 1, p. 1-18, 2003.

AMARAL, L. A.; OTTINO, J. M. Complex Networks. The European Physical Journal B-Condensed Matter and Complex Systems, Springer, v. 38, n. 2, p. 147-162, 2004.

ANASTASSIOU, D. Computational Analysis of The Synergy among Multiple Interacting Genes. Molecular Systems Biology, v. 3, n. 83, 2007.

AZUAJE, F.; DOPAZO, J. Data Analysis and Visualization in Genomics and Proteomics. : Wiley Online Library, 2005.

BANSAL, M.; BELCASTRO, V.; A, A.-I.; DI-BERNARDO, D. How to Infer Gene Networks from Expression Profiles. Molecular Systems Biology, Wiley Online Library, v. 3, n. 1, 2007.

BAR-YAM, Y. Dynamics of Complex Systems. : Addison-Wesley Reading, MA, 1997. 
BARABÁSI, A.-L. Scale-free Networks: A Decade and Beyond. Science, American Association for The Advancement of Science, v. 325, n. 5939, p. 412-413, 2009. Disponível em : <http://www.sciencemag.org/cgi/content/abstract/325/5939/412>.

BARABÁSI, A.-L. Linked: How Everything Is Connected to Everything Else and What It Means for Business, Science, and Everyday Life. : Basic Books, 2014.

BARABÁSI, A.-L. Network Science Book. Boston, MA: Center for Complex Network, Northeastern University, 2014. Disponível em : < http://barabasi.com/ networksciencebook>. Acessado : 19 Abril 2017.

BARABáSI, A. L.; ALBERT, R. Emergence of Scaling in Random Networks. Science, American Association for the Advancement of Science, v. 286, n. 5439, p. 509-512, 1999.

BARABÁSI, A.-L.; GULBAHCE, N.; LOSCALZO, J. Network Medicine: A Network-based Approach to Human Disease. Nature Reviews Genetics, Nature Publishing Group, v. 12, n. 1, p. 56-68, 2011.

BARABÁSI, A.-L.; OLTVAI, Z. N. Network Biology: Understanding The Cell's Functional Organization. Nature Reviews Genetics, Nature Publishing Group, v. 5, n. 2, p. 101-113, 2004.

BARAKAT, M. Pilares para Uma Vida Saudável: \#escolhiserfeliz. : Pandorga, 2017. ISBN 978-85-8442-176-3.

BARMAN, S.; KWON, Y.-K. A Novel Mutual Information-based Boolean Network Inference Method from Time-series Gene Expression Data. PLoS ONE, Public Library of Science, v. 12, n. 2, p. e0171097, 2017.

BARRERA, J.; CESAR-JR, R. M.; MARTINS-JR, D. C.; VENCIO, R. Z. N.; MERINO, E. F.; YAMAMOTO, M. M.; LEONARDI, F. G.; PEREIRA, C. A. B.; PORTILLO, H. A. del. Constructing Probabilistic Genetic Networks of Plasmodium falciparum from Dynamical Expression Signals of the Intraerythrocytic Development Cycle. In: Methods of Microarray Data Analysis V. : Springer, 2007. chap. 2, p. $11-26$.

BELLMAN, R. E.; DREYFUS, S. E. Applied dynamic programming. : Princeton university press, 2015.

BERKHIN, P. A Survey of Clustering Data Mining Techniques. In: Grouping Multidimensional Data. : Springer, 2006. p. 25-71.

BERLOW, N.; PAL, R. Generation of Intervention Strategy for A Genetic Regulatory Network Represented by A Family of Markov Chains. In: IEEE. Engineering in Medicine and Biology Society, EMBC, 2011 Annual International Conference of the IEEE. 2011. p. 7610-7613.

BOCCALETTI, S.; LATORA, V.; MORENO, Y.; CHAVEZ, M.; HWANG, D.-U. Complex Networks: Structure and Dynamics. Physics Reports, Elsevier, v. 424, n. 4, p. 175-308, 2006. 
BORELLI, F. F.; CAMARGO, R. Y. de; MARTINS-JR, D. C.; ROZANTE, L. C. S. Gene Regulatory Networks Inference Using A Multi-GPU Exhaustive Search Algorithm. BMC Bioinformatics, v. 14, n. S5, 2013.

BOSSOMAIER, T. R.; GREEN, D. G. Complex Systems. : Cambridge University Press, 2000.

BOZDECH, Z.; LLINAS, M.; PULLIAM, B. L.; WONG, E. D.; ZHU, J.; DERISI, J. L. The Transcriptome of The Intraerythrocytic Developmental Cycle of Plasmodium Falciparum. Plos Biology, v. 1, n. 1, Oct 2003.

BRAZHNIK, P.; FUENTE, A. de la; MENDES, P. Gene Networks: How to Put The Function in Genomics. Trends in Biotechnology, Elsevier, v. 20, n. 11, p. 467-472, 2002.

CARASTAN-SANTOS, D.; CAMARGO, R. Y.; MARTINS-JR, D. C.; SONG, S. W.; ROZANTE, L. C. S. Finding Exact Hitting Set Solutions for Systems Biology Applications Using Heterogeneous GPU Clusters. Future Generation Computer Systems, v. 67, p. 418-429, February 2017.

CARVAlHO, H. F.; RECCO-PIMENTEL, S. M. A Célula. : Manole, 2007.

CHEADLE, C.; VAWTER, M. P.; FREED, W. J.; BECKER, K. G. Analysis of Microarray Data Using Z-score Transformation. The Journal of Molecular Diagnostics, Elsevier, v. 5, n. 2, p. 73-81, 2003.

CHEN, T.; BRAGA-NETO, U. M. Statistical Detection of Intrinsically Multivariate Predictive Genes. IEEE/ACM Transactions on Computational Biology and

Bioinformatics (TCBB), IEEE Computer Society Press, v. 12, n. 4, p. 951-963, 2015.

CHU, Y.; COREY, D. R. RNA Sequencing: Platform Selection, Experimental Design, and Data Interpretation. Nucleic Acid Therapeutics, Mary Ann Liebert, Inc. 140 Huguenot Street, 3rd Floor New Rochelle, NY 10801 USA, v. 22, n. 4, p. 271-274, 2012.

CLAUSET, A.; SHALIZI, C. R.; NEWMAN, M. E. Power-law Distributions in Empirical Data. SIAM review, SIAM, v. 51, n. 4, p. 661-703, 2009.

COSTA, L. d. F.; OLIVEIRA-JR, O. N.; TRAVIESO, G.; RODRIGUES, F. A.; BOAS, P. R. V.; ANTIQUEIRA, L.; VIANA, M. P.; ROCHA, L. E. C. Analyzing and Modeling Real-world Phenomena with Complex Networks: A Survey of Applications. Advances in Physics, Taylor \& Francis, v. 60, n. 3, p. 329-412, 2011.

COSTA, L. d. F.; RODRIGUES, F. A.; TRAVIESO, G.; BOAS, P. V. Characterization of Complex Networks: A Survey of Measurements. Advances in Physics, Taylor \& Francis, v. 56, n. 1, p. 167-242, 2007.

COVER, T. M.; VAN-CAMPENHOUT, J. M. On The Possible Orderings in The Measurement Selection Problem. IEEE Transactions on Systems, Man and Cybernetics, v. 7, n. 9, p. 657-661, 1977. 
D’HAESELEER, P.; LIANG, S.; SOMOGYI, R. Genetic Network Inference: from Co-expression Clustering to Reverse Engineering. Bioinformatics, Oxford University Press, USA, v. 16, n. 8, p. 707-726, 2000.

DAVIDICH, M. I.; BORNHOLDT, S. Boolean Network Model Predicts Cell Cycle Sequence of Fission Yeast. PLoS ONE, v. 3, n. 2, p. e1672, 2008.

DE-JONG, H. Modeling and Simulation of Genetic Regulatory Systems: A Literature Review. Journal of Computational Biology, Mary Ann Liebert, Inc., v. 9, n. 1, p. 67-103, 2002.

DE-SMET, R.; MARCHAL, K. Advantages and Limitations of Current Network Inference Methods. Nature Reviews Microbiology, Nature Publishing Group, v. 8, n. 10, p. 717-729, 2010.

DEFAY, M.; POGORELCNIK, R.; WAGLER, A.; BERRY, A. et al. Impact of The Distance Choice on Clustering Gene Expression Data Using Graph Decompositions. Université Blaise Pascal, Clermont-Ferrand, France, 2012. Disponível em : <https://hal.archives-ouvertes.fr/hal-00679279v2>. Acessado : 1 Abril 2014.

DOUGHERTY, E. R. Genomic Signal Processing and Statistics. : Hindawi Publishing Corporation, 2005. ISBN 977-5945-07-0.

DOUGHERTY, E. R.; BRUN, M.; TRENT, J. M.; BITTNER, M. L. Conditioningbased Modeling of Contextual Genomic Regulation. IEEE/ACM Transactions on Computational Biology and Bioinformatics, v. 6, n. 2, p. 310-20, 2009. ISSN 1557-9964. Disponível em : <http://www.ncbi.nlm.nih.gov/pubmed/19407354>.

DOUGHERTY, E. R.; KIM, S.; CHEN, Y. Coefficient of Determination in Nonlinear Signal Processing. Signal Processing, v. 80, p. 2219-2235, 2000.

ERDöS, P.; RéNYI, A. On Random Graphs. Publ. Math. Debrecen, v. 6, p. 290-297, 1959.

ERDÖS, P.; RÉNYI, A. On A New Law of Large Numbers. Journal d'Analyse Mathématique, Springer, v. 23, n. 1, p. 103-111, 1970.

ESPINOSA-SOTO, C.; PADILLA-LONGORIA, P.; ALVAREZ-BUYLLA, E. R. A Gene Regulatory Network Model for Cell-Fate Determination during Arabidopsis Thaliana Flower Development That Is Robust and Recovers Experimental Gene Expression Profiles. Plant Cell, v. 16, n. 11, p. 2923-2939, 2004.

FAHAD, A.; ALSHATRI, N.; TARI, Z.; ALAMRI, A.; KHALIL, I.; ZOMAYA, A. Y.; FOUFOU, S.; BOURAS, A. A Survey of Clustering Algorithms for Big Data: Taxonomy and Empirical Analysis. IEEE transactions on emerging topics in computing, IEEE, v. 2, n. 3, p. 267-279, 2014.

FAITH, J.; HAYETE, B.; THADEN, J.; MOGNO, I.; WIERZBOWSKI, J.; COTTAREL, G.; KASIF, S.; COLLINS, J.; GARDNER, T. Large-scale Mapping and Validation of Escherichia coli Transcriptional Regulation from a Compendium of Expression Profiles. PLoS Biology, v. 5, p. 259-265, 2007. 
FAURE, A.; NALDI, A.; CHAOUIYA, C.; THIEFFRY, D. Dynamical Analysis of A Generic Boolean Model for The Control of The Mammalian Cell Cycle. Bioinformatics, v. 22, n. 14, p. e124-131, 2006.

FILIPPONE, M.; CAMASTRA, F.; MASULLI, F.; ROVETTA, S. A Survey of Kernel and Spectral Methods for Clustering. Pattern Recognition, Elsevier, v. 41, n. 1, p. 176-190, 2008.

FONTANA, A.; NALDI, M. C. Estudo e Comparação de Métodos para Estimação de Números de Grupos em Problemas de Agrupamento de Dados. In: INSTITUTO DE CIÊNCIAS MATEMÁTICAS E DE COMPUTAÇÃO (ICMC) DA UNIVERSIDADE DE SÃO PAULO. 2009.

FRIEDMAN, N.; LINIAL, M.; NACHMAN, I.; PE'ER, D. Using Bayesian Networks to Analyze Expression Data. Journal of Computational Biology, v. 7, n. 3-4, p. 601-20, Jan. 2000. ISSN 1066-5277.

GOVAERT, G.; NADIF, M. Co-clustering: Models, Algorithms and Applications. : ISTE, Wiley, 2013.

GREEN, D. G. Emergent Behaviour in Biological Systems. Complex Systems: from Biology to Computation, IOS Press, p. 24-35, 1993.

HEALTH, N. I. of. Genetics Home Reference. 2014. Disponível em :

<http://ghr.nlm.nih.gov/handbook.pdf>. Acessado : 25 setembro 2014.

HECKER, M.; LAMBECK, S.; TOEPFERE, S.; VAN-SOMEREN, E.; GUTHKE, R. Gene Regulatory Network Inference: Data Integration in Dynamic Models: A Review. Biosystems, Elsevier, v. 96, n. 1, p. 86-103, 2009.

HEIN, O.; SCHWIND, M.; KÖNIG, W. Scale-Free Networks. Wirtschaftsinformatik, Springer, v. 48, n. 4, p. 267-275, 2006.

HIRA, Z. M.; GILLIES, D. F. A Review of Feature Selection and Feature Extraction Methods Applied on Microarray Data. Advances in Bioinformatics, Hindawi Publishing Corporation, v. 2015, 2015.

HOLDEN, L. M. Complex Adaptive Systems: Concept Analysis. Journal of Advanced Nursing, Wiley Online Library, v. 52, n. 6, p. 651-657, 2005.

HOWE, E. A.; SINHA, R.; SCHLAUCH, D.; QUACKENBUSH, J. RNA-seq analysis in MeV. Bioinformatics, Oxford University Press, USA, v. 27, n. 22, p. 3209-3210, 2011.

HU, X.; YOO, I. Cluster Ensemble and Its Applications in Gene Expression Analysis. In: AUSTRALIAN COMPUTER SOCIETY, INC. Proceedings of The Second Conference on Asia-Pacific Bioinformatics. 2004. v. 29, p. 297-302.

IDEKER, T.; THORSSON, V.; KARP, R. M. Discovery of Regulatory Interactions through Perturbation: Inference and Experimental Design. In: Proceedings of the Pacific Symposium on Biocomputing (PSB). [S.1.: s.n.], 2000. v. 5, p. 302-313. 
IVANOV, I.; DOUGHERTY, E. R. Modeling Genetic Regulatory Networks: Continuous or Discrete? Journal of Biological Systems, v. 14, n. 2, p. 219-229, 2006.

JACOMINI, R. S.; MARTINS-JR, D. C.; SILVA, F. L.; COSTA, A. H. R. A Framework for Scalable Inference of Temporal Gene Regulatory Networks Based on Clustering and Multivariate Analysis. In: ADVANCES IN BIOINFORMATICS AND ARTIFICIAL INTELLIGENCE: BRIDIGING THE GAP. 25th International Joint Conference on Artificial Intelligence. New York, 2016.

JACOMINI, R. S.; MARTINS-JR, D. C.; SILVA, F. L.; COSTA, A. H. R. GeNICE: a novel framework for Gene Networks Inference by Clustering, Exhaustive search and multivariate analysis. Journal of Computational Biology, 2017. (in press).

JAIN, A. K.; DUIN, R. P. W.; MAO, J. Statistical Pattern Recognition: A Review. IEEE TPAMI, v. 22, n. 1, p. 4-37, 2000.

KAUFFMAN, S. A. Metabolic Stability and Epigenesis in Randomly Constructed Genetic Nets. Journal of Theoretical Biology, Elsevier, v. 22, n. 3, p. 437-467, 1969.

KAUFFMAN, S. A. Antichaos and Adaptation. Scientific American, v. 265, n. 2, p. 78-84, 1991.

KAUFFMAN, S. A. The Origins of Order: Self-organization and Selection in Evolution. : Oxford University Press, USA, 1993.

KAUFMAN, L.; ROUSSEEUW, P. Clustering by Means of Medoids. Faculty of Mathematics and Informatics, 1987. (Reports of the Faculty of Mathematics and Informatics). ISSN 0920-8577. Disponível em : <https://goo.gl/d3g7F0>.

KRACKHARDT, D.; CARLEY, K. M. PCANS Model of Structure in Organizations. : Carnegie Mellon University, Institute for Complex Engineered Systems, 1998.

LAHDESMAKI, H.; SHMULEVICH, I. On Learning Gene Regulatory Networks under the Boolean Network Model. Machine Learning, v. 52, p. 147-167, 2003.

LANGFELDER, P.; HORVATH, S. WGCNA: An R package for Weighted Correlation Network Analysis. BMC Bioinformatics, BioMed Central Ltd, v. 9, n. 1, p. 559, 2008 .

LI, F.; LONG, T.; LU, Y.; OUYANG, Q.; TANG, C. The Yeast Cell-cycle Network Is Robustly Designed. Proceedings of the National Academy of Sciences of the United States of America, National Acad Sciences, v. 101, n. 14, p. 4781-4786, 2004.

LIANG, S.; FUHRMANE, S.; SOMOGYI, R. Reveal, A General Reverse Engineering Algorithm for Inference of Genetic Network Architectures. In: Proceedings of the Pacific Symposium on Biocomputing (PSB). [S.1.: s.n.], 1998. v. 3, p. 18-29.

LIAO, T. W. Clustering of Time Series Data: A Survey. Pattern Recognition, Elsevier, v. 38, n. 11, p. 1857-1874, 2005. 
LIU, B.; FUENTE, A. de L.; HOESCHELE, I. Gene Network Inference via Structural Equation Modeling in Genetical Genomics Experiments. Genetics, Genetics Soc America, v. 178, n. 3, p. 1763-1776, 2008.

LLOYD, S. Least Squares Quantization in PCM. IEEE Transactions on Information Theory, IEEE, v. 28, n. 2, p. 129-137, 1982.

LOPES, F. M. Redes Complexas de Expressão Gênica : Síntese, Identificação, Análise e Aplicações. Tese (Doutorado) - Bioinformática, Universidade de São Paulo, 2011. Disponível em : <http://www.teses.usp.br/teses/disponiveis/95/95131/ tde-27072011-105810>.

LOPES, F. M.; JR, R. M. C.; COSTA, L. D. F. Gene Expression Complex Networks: Synthesis, Identification, and Analysis. Journal of Computational Biology, Mary Ann Liebert, Inc. 140 Huguenot Street, 3rd Floor New Rochelle, NY 10801 USA, v. 18, n. 10, p. 1353-1367, 2011.

LOPES, F. M.; MARTINS-JR, D. C.; BARRERA, J.; CESAR-JR, R. M. A Feature Selection Technique for Inference of Graphs from their Known Topological Properties: Revealing Scale-free Gene Regulatory Networks. Information Sciences, Elsevier, v. 272, p. 1-15, 2014.

LOPES, F. M.; MARTINS-JR, D. C.; CESAR-JR, R. M. DimReductionInteractive Graphic Environment for Dimensionality Reduction. arXiv preprint arXiv:0805.3964, 2008.

LOPES, F. M.; MARTINS-JR, D. C.; CESAR-JR, R. M. Feature Selection Environment for Genomic Applications. BMC Bioinformatics, v. 9, n. 1, p. 451, 2008. ISSN 1471-2105.

LOSCALZO, J.; BARABÁSI, A.-L. Systems Biology and The Future of Medicine. Wiley Interdisciplinary Reviews: Systems Biology and Medicine, Wiley Online Library, v. 3, n. 6, p. 619-627, 2011.

MACQUEEN, J. et al. Some Methods for Classification and Analysis of Multivariate Observations. In: OAKLAND, CA, USA. Proceedings of The Fifth Berkeley Symposium on Mathematical Statistics and Probability. 1967. v. 1, n. 14, p. 281-297.

MARBACH, D.; COSTELLO, J. C.; KüFFNER, R.; VEGA, N. M.; PRILL, R. J.; CAMACHO, D. M.; ALLISON, K. R.; KELLIS, M.; COLLINS, J. J.; STOLOVITZKY, G. Wisdom of Crowds for Robust Gene Network Inference. Nature Methods, Nature Publishing Group, a division of Macmillan Publishers Limited. All Rights Reserved., v. 9, n. 8, p. 796-804, 2012. ISSN 1548-7105.

MARBACH, D.; PRILL, R. J.; SCHAFFTER, T.; MATTIUSSI, C.; FLOREANO, D.; STOLOVITZKY, G. Revealing Strengths and Weaknesses of Methods for Gene Network Inference. Proceeings of the National Academy of Sciences, v. 107, n. 14, p. 6286-6291, 2010. 
MARGOLIN, A. A.; NEMENMAN, I.; BASSO, K.; WIGGINS, C.; STOLOVITZKY, G.; FAVERA, R. D.; CALIFANO, A. ARACNE: An Algorithm for The Reconstruction of Gene Regulatory Networks in A Mammalian Cellular Context. BMC Bioinformatics, BioMed Central Ltd, v. 7, n. Suppl 1, p. S7, 2006.

MARKOWETZ, F.; SPANG, R. Inferring Cellular Networks - A Review. BMC Bioinformatics, BioMed Central Ltd, v. 8, n. Suppl 6, p. S5, 2007.

MARTINS-JR, D. C. Seleção de Características e Predição Intrinsecamente Multivariada em Identificação de Redes de Regulação Gênica. Tese (Doutorado)

— Universidade de São Paulo (USP). Instituto de Matemática e Estatística, 2008.

MARTINS-JR, D. C.; BRAGA-NETO, U. M.; HASHIMOTO, R. F.; BITTNER, M. L.; DOUGHERTY, E. R. Intrinsically Multivariate Predictive Genes. IEEE Journal of Selected Topics in Signal Processing, IEEE, v. 2, n. 3, p. 424-439, 2008.

MARTINS-JR, D. C.; OLIVEIRA, E. A.; BRAGA-NETO, U. M.; HASHIMOTO, R. F.; CESAR-JR, R. M. Signal Propagation in Bayesian Networks and its Relationship with Intrinsically Multivariate Predictive Variables. Information Sciences, v. 225, p. 18-34, 2013.

MENDOZA, M. R. Exploring ensemble learning techniques to optimize the reverse engineering of gene regulatory networks. Tese (Doutorado) UNIVERSIDADE FEDERAL DO RIO GRANDE DO SUL, 2014.

MEYER, P.; KONTOS, K.; LAFITTE, F.; BONTEMPI, G. Information Theoretic Inference of Large Transcriptional Regulatory Networks. EURASIP Journal on Bioinformatics and Systems Biology, v. 2007, p. 1-9, 2007.

MONTOYA-CUBAS, C. F.; MARTINS-JR, D. C.; SANTOS, C. S.; BARRERA, J. Linear grouping of predictor instances to infer gene networks. Network Modeling Analysis in Health Informatics and Bioinformatics, v. 4, p. 34, 2015.

NAM, D.; SEO, S.; KIM, S. An Efficient Top-down Search Algorithm for Learning Boolean Networks of Gene Expression. Machine Learning, v. 65, p. 229-245, 2006.

NEWMAN, M. E. The Structure and Function of Complex Networks. SIAM review, SIAM, v. 45, n. 2, p. 167-256, 2003.

NOORT, V. V.; SNEL, B.; HUYNEN, M. A. The Yeast Coexpression Network Has A Small-world, Scale-free Architecture and Can Be Explained by A Simple Model. EMBO Reports, EMBO Press, v. 5, n. 3, p. 280-284, 2004.

NUSSBAUM, R. L.; MCINNES, R. R. Thompson \& Thompson Genética Médica. : Elsevier Brasil, 2008.

PENG, H.; LONG, F.; DING, C. Feature Selection Based on Mutual Information Criteria of Max-Dependency, Max-relevance, and Min-redundancy. IEEE Transactions on Pattern Analysis and Machine Intelligence, IEEE, v. 27, n. 8, p. 1226-1238, 2005. 
PINDAH, W.; NORDIN, S.; SEMAN, A.; SAID, M. S. M. Review of Dimensionality Reduction Techniques Using Clustering Algorithm in Reconstruction of Gene Regulatory Networks. In: IEEE. Computer, Communications, and Control Technology (I4CT), 2015 International Conference on. 2015. p. 172-176.

PINNA, A.; SORANZO, N.; HOESCHELE, I.; FUENTE, A. de-la. Simulating Systems Genetics Data with SysGenSIM. Bioinformatics, Oxford University Press, USA, v. 27, n. 17, p. 2459-2462, 2011.

PUDIL, P.; NOVOVICOVÁ, J.; KITTLER, J. Floating Search Methods in Feature Selection. Pattern Recognition Letters, v. 15, p. 1119-1125, 1994.

QIAN, X.; DOUGHERTY, E. R. Validation of Gene Regulatory Network Inference Based on Controllability. Quantitative Assessment and Validation of Network Inference Methods in Bioinformatics, Frontiers Media SA, p. 33, 2015.

R Core Team. R: A Language and Environment for Statistical Computing. Vienna, Austria, 2015. Disponível em : <https://www.R-project.org/>.

RISTEVSKI, B. A Survey of Models for Inference of Gene Regulatory Networks. Nonlinear Analysis: Modelling and Control, v. 18, n. 4, p. 444-465, 2013.

RUSSELL, S.; NORVIG, P. Artificial Intelligence: A Modern Approach. : Pearson Higher Ed, 2016.

SAEYS, Y.; INZA, I.; LARRAÑAGA, P. A Review of Feature Selection Techniques in Bioinformatics. Bioinformatics, Oxford University Press, USA, v. 23, n. 19, p. 2507-2517, 2007.

SÁNCHEZ, L.; THIEFFRY, D. A Logical Analysis of The Drosophila Gap-gene System. Journal of Theoretical Biology, v. 211, n. 2, p. 115-141, 2001.

SHALON, D.; SMITH, S. J.; BROWN, P. O. A DNA Microarray System for Analyzing Complex DNA Samples Using Two-color Fluorescent Probe Hybridization. Genome Research, p. 639-45, 1996.

SHANNON, P.; MARKIEL, A.; OZIER, O.; BALIGA, N. S.; WANG, J. T.; RAMAGE, D.; AMIN, N.; SCHWIKOWSKI, B.; IDEKER, T. Cytoscape: A Software Environment for Integrated Models of Biomolecular Interaction Networks. Genome Research, Cold Spring Harbor Lab, v. 13, n. 11, p. 2498-2504, 2003.

SHMUlEVICH, I.; DOUGHERTY, E. R. Genomic Signal Processing. : Princeton University Press, 2014.

SHMULEVICH, I.; DOUGHERTY, E. R.; KIM, S.; ZHANG, W. Probabilistic Boolean Networks: A Rule-based Uncertainty Model for Gene Regulatory Networks. Bioinformatics, Oxford University Press, USA, v. 18, n. 2, p. 261-274, 2002.

SNIJDERS, T. A. Statistical Models for Social Networks. Annual Review of Sociology, Annual Reviews, v. 37, p. 131-153, 2011. 
SNUSTAD, D.; SIMMONS, M. Fundamentos de Genética, (Seventh Edition). : Guanabara Koogan, 2017. ISBN 9788527730860.

STROGATZ, S. H. Exploring Complex Networks. Nature, Nature Publishing Group, v. 410, n. 6825 , p. $268-276,2001$.

STYCZYNSKI, M. P.; STEPHANOPOULOS, G. Overview of Computational Methods for The Inference of Gene Regulatory Networks. Computers \& Chemical Engineering, v. 29, n. 3, p. 519-534, 2005.

THOMPSON, J.; THOMPSON, M. Genética Médica. 5ª Edição. : Editora Guanabara Koogan, Rio de Janeiro, 60p, 1993.

TRAVERS, J.; MILGRAM, S. The Small World Problem. Phychology Today, JSTOR, v. 1, p. 61-67, 1967.

VELCULESCU, V. E.; ZHANG, L.; VOGELSTEIN, B.; KINZLER, K. W. Serial Analysis of Gene Expression. Science, v. 270, p. 484-487, 1995.

VIGNES, M.; VANDEL, J.; ALLOUCHE, D.; RAMADAN-ALBAN, N.; CIERCO-AYROLLES, C.; SCHIEX, T.; MANGIN, B.; GIVRY, S. de. Gene Regulatory Network Reconstruction Using Bayesian Networks, The Dantzig Selector, The Lasso and Their Meta-analysis. PLoS ONE, Public Library of Science, v. 6, n. 12, p. e29165, Jan. 2011. ISSN 1932-6203. Disponível em : <http://dx.plos.org/10.1371/journal.pone.0029165>.

WANG, Z.; GERSTEIN, M.; SNYDER, M. RNA-Seq: A Revolutionary Tool for Transcriptomics. Nature Reviews Genetics, Nature Publishing Group, v. 10, n. 1, p. 57-63, 2009.

WATTS, D. J. Small Worlds: The Dynamics of Networks between Order and Randomness. : Princeton University Press, 1999.

WATTS, D. J.; STROGATZ, S. H. Collective Dynamics of 'Small-World' Networks. Nature, Nature Publishing Group, v. 393, n. 6684, p. 440-442, 1998.

ZHANG, B.; HORVATH, S. A General Framework for Weighted Gene Co-expression Network Analysis. Statistical Applications in Genetics and Molecular Biology, v. 4, n. 1, 2005.

ZHANG, Y.; QIAN, M.; OUYANG, Q.; DENG, M.; LI, F.; TANG, C. Stochastic Model of Yeast Cell-cycle Network. Physica D: Nonlinear Phenomena, Elsevier, v. 219, n. 1 , p. 35-39, 2006. 